\title{
ALEXANDRE SAADEH
}

\section{Transtorno de identidade sexual:}

um estudo psicopatológico de transexualismo masculino e feminino

Tese apresentada ao Departamento de Psiquiatria da Faculdade de Medicina da Universidade de São Paulo para obtenção do título de Doutor em Ciências.

Área de Concentração: Psiquiatria

Orientadora: Prof ${ }^{a}$. Dr ${ }^{\mathrm{a}}$. Carmita Helena Najjar Abdo

SÃO PAULO 


\section{FICHA CATALOGRÁFICA}

Preparada pela Biblioteca da

Faculdade de Medicina da Universidade de São Paulo

Creprodução autorizada pelo autor

Saadeh, Alexandre

Transtorno de identidade sexual : um estudo psicopatológico de transexualismo masculino e feminino / Alexandre Saadeh. -- São Paulo, 2004.

Tese(doutorado)--Faculdade de Medicina da Universidade de São Paulo.

Departamento de Psiquiatria.

Área de concentração: Psiquiatria.

Orientadora: Carmita Helena Najjar Abdo.

Descritores: 1.TRANSTORNOS SEXUAIS E DA IDENTIDADE SEXUAL/diagnóstico 2.TRANSTORNOS SEXUAIS E DA IDENTIDADE SEXUAL/terapia 3.TRANSTORNOS SEXUAIS E DA IDENTIDADE SEXUAL/psicologia 4.TRANSSEXUALISMO/diagnóstico 5.TRANSSEXUALISMO/terapia 6.TRANSSEXUALISMO/psicologia 7.TRANSSEXUALISMO/histologia 8.TRANSTORNO DA PERSONALIDADE/ psicologia 9.DEPRESSÃO/psicologia 10.PSICOTERAPIA DE GRUPO/métodos 11.ENTREVISTA PSIQUIÁTRICA PADRONIZADA 
Não creio que seja verdade o que dizem, Que ao viajar alguém possa se transformar em outra pessoa: o que acontece é que nos livramos de nós mesmos, de nossas obrigações e nosso passado, tal como reduzimos tudo o que possuímos aos poucos objetos necessários que vão dentro da mala. A parte mais pesada de nossa identidade sustenta-se sobre o que os outros sabem e pensam de nós. Olham-nos e sabemos que sabem, e no silêncio forçam-nos a ser o que esperam que sejamos. (ANTONIO MUÑOZ MOLINA)

Esta tese é dedicada a meus pais. Imperfeitos, batalhadores, admiráveis. Devo-Ihes a vida, valores e o respeito pelos outros, pela diferença. Só existo graças ao esforço carinhoso, compreensivo e constante de vocês. Continuem me amando que eu sigo adiante.

A Antônio Carlos Diniz Que me ensinou a respeitar as diferenças E a valorizar o particular. 


\section{Agradecimentos}

Você pensa saber quem é e de repente descobre

Que se transformou no que outros querem enxergar em você, e pouco a pouco vai ficando mais estranho para si mesmo, e sua própria sombra é o espião que segue seus passos, e em seus olhos você vê o olhar dos que o acusam, dos que mudam de calçada para não cumprimentá-lo e olham-no de soslaio e cabeça baixa ao cruzarem com você. (ANTONIO MUÑOZ MOLINA)

Esta tese teve vários colaboradores. Incansáveis batalhadores nessa jornada inimaginável, muitas vezes solitária e de acompanhamento à distância pelo terreno do humano e do imponderável. Nenhum deles acusador. O tempo todo solidários.

Agradeço Tânia Regina de Oliveira, mais que anjo da guarda, comadre, amiga e presença constante. Mão direita na conclusão desse trabalho. Ajuda sempre presente na digitação, recuperação de dados, cafés e elaboração final da tese.

Aos queridos ex-médicos residentes da Departamento de Psiquiatria da Faculdade de Medicina da Universidade de São Paulo, atuais psiquiatras, pela participação na aplicação das escalas: Ana Maria Galetti, Andrea Bernardi Mazzoleni, Daniela Sabbatini S. Lobo, Flávia Puppi, Paula Villela Nunes, Renato José Vieira, Sandra Petresco, Sérgio Rachman e Vanessa Flaborea Favaro. 
Aos meus colaboradores psicólogos, ex-alunos da Pontificia Universidade Católica de São Paulo, amigos, leais e sempre presentes: Emílio Figueiredo Netto, Desirèe Monteiro Cordeiro e Patricia Gwercman.

A psicóloga e psicodramatista, amiga e incentivadora de longa data, Kathya Regina Mutti.

A equipe do Ambulatório de Endocrinologia do Desenvolvimento da Disciplina de Endocrinologia do Hospital das Clínicas da Faculdade de Medicina da Universidade de São Paulo, por facilitar, acompanhar, incentivar e permitir que esse trabalho se desenvolvesse: Prof ${ }^{a}$. Dr ${ }^{\mathrm{a}}$. Berenice Bilharinho de Mendonça, Prof ${ }^{\mathrm{a}}$. Dr ${ }^{\mathrm{a}}$. Elaine Maria Frade Costa, psicóloga Elisa D.R. Ugarte Verduguez e a psicóloga Marlene Perez Inacio.

A secretária da pós-graduação, Eliza Sumie Sogabe Fukushima. Sem ela esse trabalho seria impossível.

As secretárias do Serviço de Psicoterapia do Instituto de Psiquiatria do Hospital das Clínicas da Faculdade de Medicina da Universidade de São Paulo, Júlia Regina Roque, Rosely Aparecida Pereira Antonio e Diva Candida da Silva. Sem elas não daria para organizar o atendimento. Seu apoio e carinho foram fundamentais.

A secretária do ProSex, Projeto Sexualidade do Instituto de Psiquiatria do Hospital das Clínicas da Faculdade de Medicina da Universidade de São Paulo, Maria da Graça Paoletti, mulher incansável e companheira de jornada. Sem suas brigas o trabalho seria mais fácil, mas menos agradável.

A Creusa Dal Bó pelos serviços de estatística.

A Vagner Maringolo pela revisão ágil e precisa. 
A Isabel Galhardo Giannotti pela carinhosa e dedicada versão do resumo em inglês.

A Sidnei Jacob, educador físico, por saber suportar maus humores e estimular a coordenação e dedicação corporal a essa jornada.

A Marina Fátima Barbedo Menezes, minha interlocutora na vida. Amiga de todas as horas e todos os lugares.

A Soraya Saadeh, minha irmã, querida auxiliar de informática nas horas mais difíceis e Mariana Saadeh de Albuquerque, sobrinha mais que amada, pelo auxílio bibliográfico.

Aos meus pacientes, especialmente os transexuais, por confiar e abrir suas vidas. Aprendi muito e continuo aprendendo. Sou devedor na riqueza desse contato.

A paciente T. por me escolher como participante num momento tão especial em sua vida, seu casamento.

Por fim, como sempre, a Profa. Dra . Carmita Helena Najjar Abdo. Terminar a lista de agradecimentos reflete a importância dessa mulher em minha vida. Como professora, médica, psiquiatra, orientadora, estimuladora. Minha eterna gratidão por confiar em mim numa relação em muitos momentos difícil, às vezes áspera, mas verdadeira sempre. 


\section{SUMÁRIO}

Lista de tabelas

Lista de gráficos

Resumo

Summary

1 INTRODUÇÃ

2 REVISÃO BIBLIOGRÁFICA ................................................ 09

2.1 Aspectos mitológicos................................................. 11

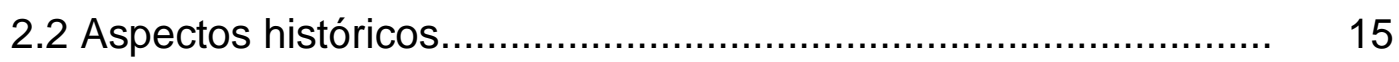

2.3 Elementos transculturais................................................. 18

2.4 Do século XX aos nossos dias: a visão cientítífica..................... 20

2.5 A questão transexual no Brasil.......................................... 42

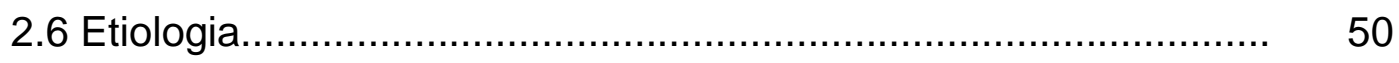

2.6.1 Perspectivas biológicas.............................................. 50

2.6.2 Perspectivas psicológicas............................................ 55

2.7 Prevalência e incidência................................................. 78

2.8 Diagnóstico............................................................. 82

2.9 Diagnóstico diferencial.................................................. 111

2.10 Comorbidade ................................................................ 115

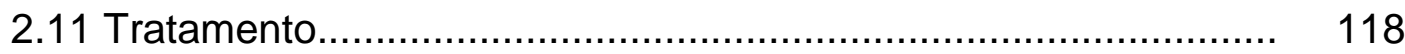

2.12 Seguimento pós-cirúrgico............................................... 139

2.13 Outras questões relevantes............................................ 142

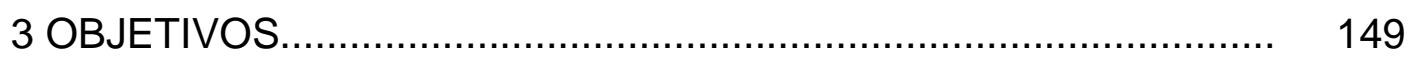

4 CASUÍSTICA E MÉTODO ....................................................... 151 
4.1 Cálculo do tamanho da amostra............................................... 152

4.1.1 Metodologia do cálculo do tamanho da amostra....................... 153

4.1.2 Resultados do cálculo do tamanho da amostra........................ 155

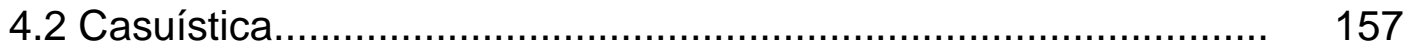

4.3 Metodologia da pesquisa....................................................... 163

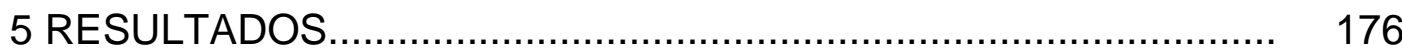

5.1 Análise descritiva dos dados demográficos................................ 177

5.2 Comparação dos grupos........................................................... 181

5.3 Avaliação estatística da aplicação das entrevistas e escalas

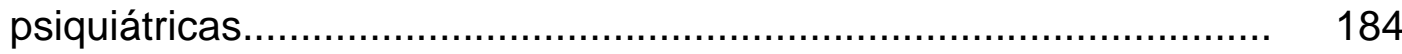

5.3.1 Comparação entre os grupos para as escalas e entrevistas para SCID-IP, BDI e HAM-D ..................................................... 190

5.32 Comparação entre os grupos para a entrevista de personalidade (SIDP-R) ………………………..................... 193

5.4 Psicoterapia em grupo........................................................... 196

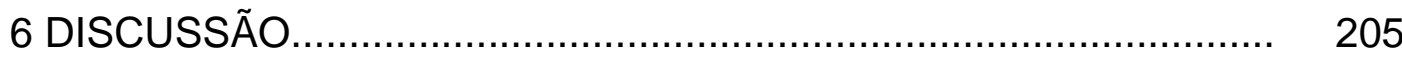

6.1 Caracterização demográfica........................................................ 208

6.2 Resultado SCID-I/P................................................................ 214

6.3 Resultados das aplicações da escala de avaliação para depressãode Hamilton e inventário de Beck …………………....... 215 6.4 Resultados das aplicações da entrevista para transtorno de personalidade (SIDP-R) ........................................................... 216

6.5 Análise dos resultados da psicoterapia...................................... 218

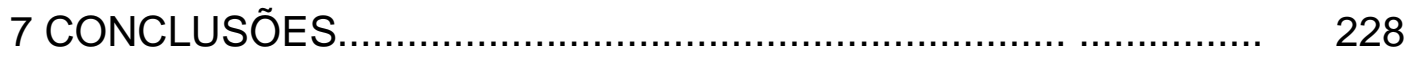

8 REFERÊNCIAS BIBLIOGRÁFICAS.............................................. 231 


\section{LISTA DE TABELAS}

Tabela 1 - Desorientação e indecisão de sexo e gênero (homens) Harry Benjamin - 1966

Tabela 2 - Definição de identidade de gênero

Money - 1994; Money, Ehrhardt - 1996

Tabela 3 - Definição de identidade de gênero segundo diferentes escolas psicológicas

Tabela 4 - Transexualismo primário (verdadeiro) - Dolan - 1987

Tabela 5 - Papel do endocrinologista no tratamento de transexuais

Tabela 6 - Resultados da pontuação observada no BDI aplicado no início do estudo e após dois anos de psicoterapia grupal $-n=7$

Tabela 7 - Tamanhos de amostra para diferentes médias e respectivos desvios-padrão de variação de BDI

Tabela 8 - Dados demográficos

Tabela 9 - Freqüências absolutas e relativas da procedência dos pacientes

Tabela 10 - Freqüências absolutas e relativas da religião dos pacientes

Tabela 11 - Freqüências absolutas e relativas da profissão dos pacientes.

Tabela 12 - Valores de média de idade, segundo os grupos masculino e feminino

Tabela 13 - Comparação dos valores de freqüências absolutas e relativas dos antecedentes pessoais entre os grupos masculino e feminino

Tabela 14 - Comparação dos valores de média das idades de início de transtorno de identidade sexual, transvestismo e uso de hormônios entre os grupos masculino e feminino.

Tabela 15 - Resultados das aplicações inicial e final de BDI e HAM-D por paciente 
Tabela 16 - Resultados da aplicação de SCID

Tabela 17 - Resultados da aplicação inicial da entrevista de personalidade (SIDP-R)

Tabela 18 - Resultados da aplicação final da entrevista de personalidade (SIDP-R

Tabela 19 - Valores de freqüências absolutas e relativas de BDI e HAM-D inicial, segundo os grupos masculino e feminino

Tabela 20 - Valores de média, dependendo do escore de HAM-D, segundo BDI inicial, nos grupos masculino e feminino

Tabela 21 - Valores de média, dependendo dos escores de BDI e HAM-D, segundo os grupos masculino e feminino

Tabela 22 - Distribuição e número de sessões grupais

Tabela 23 - Distribuição de faltas por paciente 


\section{LISTA DE GRÁFICOS}

Gráfico 1- Correlações entre idade de início de uso de hormônios e início de transvestismo nos grupos masculino e feminino 184

Gráfico 2 - Comparação de BDI e HAM-D iniciais nos grupos 191

Gráfico 3 - BDI "versus" HAM-D 193 


\section{RESUMO}

Saadeh A. Transtorno de identidade sexual: um estudo psicopatológico de transexualismo masculino e feminino [tese]. São Paulo: Faculdade de Medicina, Universidade de São Paulo; 2004. 266p.

Apesar de recentes, os estudos a respeito de Transtorno de Identidade Sexual ou de Gênero, especificamente o transexualismo, têm buscado maior precisão diagnóstica e etiológica. No Brasil, é a partir de 1997, com a normatização do Conselho Federal de Medicina, que se intensifica o atendimento e tratamento, inclusive o cirúrgico, dessa população. Essa pesquisa propôs-se a avaliar a presença de transtornos de eixo I, depressão e personalidade, além de caracterizar e comparar demograficamente uma população de 33 transexuais ( 25 masculinos e 8 femininos). Também teve como objetivo comparar a presença de Depressão e Transtornos de Personalidade após dois anos de psicoterapia grupal psicodramática, além de estruturar um temário específico para essa psicoterapia. Para tanto foram aplicados a entrevista estruturada SCID-I/P, Inventário de Depressão de Beck (BDI), Escala de Hamilton para Avaliação de Depressão (HAM-D 21 itens) e Entrevista Estruturada para Distúrbios da Personalidade pelo DSMIII-R. As características demográficas gerais não variaram nos dois grupos, apesar de que entre os transexuais masculinos existe uma correlação significativa entre início de transvestismo e uso de hormônios. Outros resultados demográficos necessitariam de um estudo em maior escala para apresentar significância. Não houve presença de nenhum diagnóstico psiquiátrico prevalecente. Os mais comuns foram depressão, ansiedade e abuso de substâncias químicas. Quanto à depressão, houve predomínio de sintomas depressivos e não de quadro clínico. Tanto BDI, quanto HAM-D, no início, apresentaram valores correlatos no grupo masculino. Isso não se repetiu no grupo feminino. Após dois anos de psicoterapia, houve decréscimo significativo dos valores de BDI para os dois grupos $(p<0,001)$, 0 que não se repetiu com HAM-D. Quanto aos transtornos e traços de personalidade, nenhum dado estatisticamente significativo foi encontrado, nem no momento inicial nem após dois anos de psicoterapia, o que provavelmente se deve ao pequeno número de indivíduos. Os transtornos de personalidade mais comumente encontrados foram histriônico, evitador, esquizóide, dependente, passivo-agressivo e narcisista. Quanto ao temário da psicoterapia, esse foi estabelecido e se mostrou de grande valia na abordagem e acompanhamento dessa população. Itens como preconceito, fantasias, dificuldades, comportamento sexual, transexualismo, direitos e cidadania, doenças sexualmente transmissíveis e prostituição, transexualismo, cirurgia e psicoterapia foram exaustivamente abordados e trabalhados.

Descritores: Transtornos sexuais e da identidade sexual, transsexualismo, transtorno da personalidade, depressão, psicoterapia de grupo e entrevista psiquiátrica padronizada. 


\section{SUMMARY}

Saadeh A. Sexual identity disorder: a psychopathological study of male-tofemale and female-to-male transsexuals [thesis]. São Paulo: "Faculdade de Medicina, Universidade de São Paulo"; 2004. 266p.

Although recent, studies about Sexual or Gender Identity Disorders more specifically transsexualism, have searched for more diagnostic and etiologic accuracy. In Brazil, it was after 1997, with the standardized version of the Federal Council of Medicine, that care and treatment including surgical procedures of this population became intensive. This research proposed to evaluate the presence of axis $I$, depression and personality as well as characterizing and comparing demographically a population of 33 transsexuals (25 male-to-female and 8 female-to-male). It also had as an objective to compare the presence of depression and personality disorders after two years of group therapy, besides structuring a specific list of topics for such psychotherapy. In order to do so, the Structured Interview SCID-I/P, Beck Depression Inventory (BDI), Hamilton Scale for Evaluation of Depression (21 items HAM - D) and Structured Interviews for personality disorders by the DSM-III-R were applied.

The general demographic characteristics did not vary between the groups although among male-to-female transsexuals the presence of a significant correlation between the start of transvestism and the use of hormones. Other demographic results would require a larger scale study to show significance. There was not any prevalent psychiatric diagnosis. The most common were depression, anxiety and substance abuse. As for depression, there was preponderance 0 depressive symptoms opposite to of clinic depression scene. In the beginning, both BDI and HAM-D presented correlate values to the male group. The same did not happen in the female group. After two years of psychotherapy, there was a significant decrease of BDI values for both groups $(p<0,001)$. The same did not happen with HAM-D. As for disorders and personality traits, no statistically significant data was found. Neither in the first moments or after the two years of psychotherapy. Such fact probably happened due to the limited number of individuals. Personality disorders more commonly encountered were histrionic, avoiding, schizoid, dependent, passive-aggressive and narcissistic. As for the topics of psychotherapy, this was established and shown to be of great, value to both approach and caring of this population. Items such as: prejudice, fantasies, difficulties, sexual behavior, transsexuals, rights and citizenship, sexually transmissible diseases and prostitution, surgery and psychotherapy were deeply approached and worked upon.

Keywords: Sexual and identity disorders, transsexualism, personality disorders, depression, group psychoteraphy, standard psychiatric interview. 
1 INTRODUCÃ̃O 

INTRODUÇÃO

Somos atraídos por algumas pessoas não tanto pelo que elas são, mas pela maneira como nos fazem sentir sobre nós mesmos. (LYNN SCHOOLER)

Dezembro de 2003. Vicente de Carvalho, litoral de São Paulo. Enquanto enquanto toca a marcha nupcial dentro da igreja católica e aguarda-se a entrada da noiva, tento colocar em ordem as emoções. Sem muito sucesso.

A associação de idéias me carrega para 1982, para o curso de Medicina Legal. Dentro das aulas de Psicopatologia Forense, os alunos são apresentados ao assunto transexualismo e aos pacientes transexuais. $O$ Professor Doutor Armando Canger Rodrigues, único professor titular na graduação a dar aulas e estar presente durante todo seu curso, faz força, mas não consegue retirar a aura de marginalidade e bizarrice que se apresenta ligados ao tema.

O que faz que um homem se vista como mulher e queira a todo custo retirar seu pênis? E pior, em termos morais, na visão de quarto-anistas de medicina da Faculdade de Medicina da Universidade de São Paulo, que se prostitua? E o contrário, então, uma mulher querer se tornar homem? Inconcebível!

O ano é 1982, a explosão da epidemia de AIDS ainda não se configurou no Brasil, a ditadura ainda se faz presente, nos estertores, mas 
viva. Os valores morais são rígidos e fica claro que depois do processo do cirurgião plástico Roberto Farina, não há nada a ser feito pelos transexuais a não ser demovê-los dessa "obsessão" de que são de outro sexo e é dever da Medicina ajudá-los a superar essas idéias.

A visão de seres bizarros, de homossexuais enrustidos, de travestis problemáticos, persegue e se impõe. A percepção de que nos agride a existência de tais seres provoca-nos repugnância por eles. O processo é o mesmo que ocorre em toda a sociedade. A origem do preconceito é a ignorância, a visão particular e tendenciosa a partir dos próprios e restritos referenciais.

Desde pequenos, educam-se crianças dentro da noção tomada como verdadeira de que existem apenas duas categorias sexuais, os homens e as mulheres. A natureza, Deus, a biologia determinou que fosse assim. Toda e qualquer variação é anômala e, portanto, doentia, seja no pensamento médico, seja no conceito moral.

Crescemos e nos criamos reconhecendo-nos e aos outros dentro dessa referência. A possibilidade da existência de outras categorias sexuais e de gênero parece irreal, o que estimula o preconceito e a dificuldade de entendimento de variações, diferenças e particularidades.

E com relação ao assunto sexual, variações e excessões são sinônimos de exclusão, condenação ou doença.

Por mais liberal que fosse a formação na Faculdade, o momento histórico era complexo e pouco ajudou a desfazer preconceitos. A intervenção de professores interessados em estimular a curiosidade 
científica ao invés do preconceito e discriminação moral, ajudou, mas não extingüiu a sensação de estranheza frente ao fenômeno.

Com o passar dos anos e da leitura de pesquisas, na grande maioria, internacionais, um novo padrão conceitual menos tendencioso foi se estabelecendo, sem, contudo, dissipar o preconceito.

E foi com esse preconceito revisado que em 1998 iniciei o trabalho com transexuais no ProSex (Projeto Sexualidade do Instituto de Psiquiatria do Hospital das Clínicas da Faculdade de Medicina da Universidade de São Paulo), após a normatização proposta pelo CFM (Conselho Federal de Medicina) em 1997.

O ProSex, desde a formação, já havia dado atendimento a essa população, mas a procura era pequena e os recursos médicos, restritos à psicoterapia, eram pouco atraentes para a maioria dos transexuais. Com a publicação da normatização do CFM, autorizando a cirurgia de redesignação sexual em hospitais-escolas ou ligados à pesquisa e, sob circunstâncias determinadas, a realidade mudou e o afluxo de pacientes aumentou.

Em 1998, ainda ignorante e preconceituoso com relação ao tema e aos transexuais, assustavam-me a intensidade e agressividade presentes na vida e no discurso dessa população.

As experiências estrangeiras, décadas à frente, propunham uma estrutura, um protocolo de atendimento, mas não explicavam nem detalhavam a maneira de realizá-lo. Isso sem contar todas as diferenças culturais do Brasil e as restrições presentes na normatização do CFM.

Mesmo assim foi dado início, de maneira lenta, mas com vontade. 
Alguns pacientes assustavam pela transformação já presente e forçavam a situações que se hoje parecem fáceis, na época eram de difícil solução. Exemplo: como interpelar um transexual feminino, já utilizando hormônios e com nome oficial de mulher, mas que à frente se materializa como um homem careca, forte e peludo? Os hormônios realizam maravilhas, o problema é como lidar com elas e aceitá-las.

Tudo foi se resolvendo aos poucos e atualmente essa questão parece distante do cotidiano e dos outros problemas a ser enfrentados. Mas a história desses detalhes valoriza e agrega aspecto humano ao trabalho construído. Se não houvesse a dificuldade do preconceito e a necessidade de superá-lo, essa pesquisa não teria o mesmo valor e riqueza. Foi graças ao trabalho com os transexuais que a ignorância e os preconceitos foram dissipados, o conhecimento, construído.

Retomando, é em 1998 que chega J., ou T., como é conhecida hoje. História típica de um transexual masculino: desde pequena foi diferente dos outros meninos, sempre soube que era mulher, nunca se masturbou, odeia "esse apêndice" chamado pênis, sempre urinou sentada, nunca teve relação sexual com mulheres, fica deprimida com sua condição. Essa é a história padrão de quase todos os transexuais que nos procuram e que se modifica com o tempo e esforço conjuntos. Contudo, T. apresentava particularidades na história de vida. Tinha uma relação conjugal de quase 20 anos, à época, com um mesmo e único parceiro. Tinha um filho adolescente adotado. Vivia e era aceita como mulher na comunidade em que vivia. 
Essa paciente enfrentou um processo de quatro anos de psicoterapia grupal antes de ser indicada para a cirurgia de redesignação sexual. Foram quatro anos de vivências intensas e importantes. De aprendizado mútuo e reconhecimento de experiências e afetos profundos.

E voltando ao início dessa história, é ela quem, entra vestida de noiva, na igrejinha de Vicente de Carvalho. Sua filhinha adotiva de dois anos vem como dama-de-honra e seu filho adotivo, já um homem de 18 anos, é quem a conduz, de braços dados, ao altar.

Emociono-me a cada momento dessa cerimônia. Nos cumprimentos dos noivos choramos juntos. É uma vitória, sem dúvida. Um capítulo feliz na vida de T.. Mas não é um final feliz. A mudança anatômica e mesmo jurídica facilitam, mas as outras pessoas sempre terão o que dizer de seus traços físicos. Dúvidas vão continuar existindo. "Será mesmo uma mulher?". "Será um travesti?". Só quando virem seus documentos é que poderão se acalmar, pois documentos oficiais não mentem, nem enganam. Mesmo assim, a convivência com a dúvida será uma constante na vida de T.. Mas o melhor, ela aprendeu a conviver e sobreviver a isso.

Ter sido seu padrinho de casamento é ao mesmo tempo uma realização profissional e uma satisfação pessoal. Havia muito não sentia pela Medicina o que senti nesse 20 de dezembro de 2003. A realidade de ter ajudado a construir uma trajetória de conquista, paz e tranqüilidade com alguém. De ter tido a possibilidade de desenvolver toda sua potencialidade e saber que ela é real, verdadeira e fundamental, e não delirante em sua vida. Uma situação e uma realidade diferentes, porém reais e valiosas, como cada 
experiência humana, aproximando-a de sua solidão e particularidade, que muitas vezes só se permitem revelar em uma sessão de psicoterapia.

Iniciar uma tese com esse tipo de testemunho pode parecer piegas e sem necessidade. Essa, no entanto, é a forma de reforçar aquilo em que acredito. $\mathrm{Na}$ dissertação de mestrado, acentuei a necessidade de abordagem da relação médico-paciente com os alunos de quinto ano de medicina. No doutorado, é a partir desse ponto que inicio. Valorizar a relação médico-paciente com os pacientes transexuais. Eles já são "coisificados" no dia-a-dia. E no tratamento médico é um erro tratá-los como objetos. Ou pior, abjetos. Restituir a humanidade em sua particularidade é o mínimo que se pode exigir de um psiquiatra.

Não é tarefa fácil. Ainda mais quando desde pequenos acostumamnos a acreditar na existência de dois sexos: homens e mulheres, nada além disso. Com o tempo aprendemos, a duras penas, que há outras possibilidades, que não são opções pessoais, mas condições impostas pela biologia, meio social, genética ou pelo psicológico aos indivíduos. A transgressão à regra dos dois sexos custa caro ao transgressor e a quem a enxerga com outra possibilidade. Rompe com a norma e, portanto, estabelece novas formas de ser e pensar. A sexualidade é, aliás, um campo de transgressão e evolução constantes. Historicamente sempre foi. É só avaliar sua história.

Quanto à expressão "sexo" para designar homem e mulher, masculino e feminino, não a considero adequada. Outra possibilidade existente tanto em português como em outros idiomas é melhor aplicado: a 
palavra "gênero". HOUAISS (2001) dá ao termo "sexo" seis significados, ligados especificamente ao sentido biológico e anatômico. Já para "gênero", estabelece treze, nenhum sexualmente, nem biologicamente explícito. Em linhas gerais, a caracterização do termo é de "conceito geral que engloba todas as propriedades comuns que caracterizam um dado grupo ou classe de seres ou de objetos" (HOUAISS, 2001, p. 1441).

"Gênero" é a expressão ideal pois descentraliza a noção predominante de que ser masculino ou feminino, homem ou mulher é anatomicamente determinada. A construção social e psicológica segue direções nem sempre compatíveis com a determinação biológica. Dessa aparente contradição surge a transgressão e toda dificuldade em entender e lidar com o assunto.

E é da satisfação implícita com o trabalho assistencial e de pesquisa que surge o tema dessa tese. Nos próximos capítulos serão detalhados os objetivos desse trabalho, relatada exaustiva revisão bibliográfica para localizar o leitor quanto à produção relativa ao tema, apresentada a pesquisa realizada, enquanto método e casuística, caracterizada a população pesquisada e discutidos os resultados. Na seqüência, têm-se a discussão dos dados obtidos e a conclusão. A tese termina com a apresentação das referências bibliográficas. 
2 REVISÃO BIBLIOGRÁFICA 


\title{
2. REVISÃO BIBLIOGRÁFICA
}

\author{
Já perscrutamos bastante as profundezas \\ dessa consciência e é chegado o momento \\ de continuarmos a examiná-la. Não o fazemos \\ sem emoção ou estremecimento. \\ Nada existe de mais terrível que esse tipo de contemplação. \\ Os olhos do espírito não podem encontrar em nenhum \\ lugar nada mais ofuscante, nada mais tenebroso que o homem; \\ não poderão fixar-se em nada mais temível, \\ mais complicado, mais misterioso e mais infinito. \\ Existe uma coisa que é maior que o mar: o céu. \\ Existe um espetáculo maior que o céu: \\ é o interior de uma alma. \\ (VICTOR HUGO)
}

Serão apresentados nesse capítulo aspectos mitológicos, históricos, transculturais e científicos ligados ao tema de transtorno de identidade sexual, ou de gênero, mais especificamente ao transexualismo. Esses dados nos remetem à evolução de costumes e crenças a respeito das condições de gênero, sexo e suas influências no pensamento científico e propostas de intervenção e tratamento. As dificuldades e tentativas de entender, o fenômeno em várias áreas do conhecimento se estendem desde as explicações ou simbolizações mitológicas até as conceituações conceituações científicas mais aceitas e atuais, mesclando-se e, com isso, produzindo um conhecimento dinâmico e rico a respeito do tema.

A presença de uma dificuldade diagnóstica é explicitada e problematizada em face à confusão de termos e à inexistência de um método objetivo de identificação dos quadros, além das comorbidades 
frequentes com transtornos psiquiátricos e a existência de diagnósticos diferenciais que mimetizam ou confundem o diagnóstico.

É a partir da articulação de todas as partes desse conjunto de conceitos e aspectos que se configura o campo de pesquisa dos transtornos de identidade sexual ou de gênero.

Inicia-se o capítulo com a apresentação dos mitos relacionados ao assunto; a seguir aspectos históricos e transculturais relacionados ao tema e, na seqüência, etiologia, prevalência e incidência, diagnóstico, comorbidade, tratamento e outras questões relevantes e interligadas como, por exemplo, questões jurídicas, de saúde pública, e aquelas relacionadas aos parceiros e à visão das pessoas a respeito do tema.

\section{$2.1 \quad$ Aspectos mitológicos}

Na mitologia greco-romana, segundo GREEN (1998), encontra-se referência a Vênus Castina, a qual, para GREGERSEN (1983, p. 71) seria a "deusa que se preocupa e simpatiza com os anseios de almas femininas presas em corpos masculinos". Uma das várias denominações e especificações da deusa do amor, mais conhecida entre os gregos por Afrodite.

Outras referências mitológicas são encontradas em indivíduos cuja mudança de sexo não se dá por desejo, mas, sim, por punição divina. GREEN (1998) cita o mito do adivinho Tirésias de Tebas, que, ao ascender 
ao monte Citerão, encontra duas cobras copulando. Ao separá-las e matar a fêmea, ele é punido pelos deuses, sendo transformado em mulher. Sete anos depois, ao se adaptar a essa condição e forma femininas, Tirésias sobe o mesmo monte. Ao se deparar com a mesma cena de duas cobras copulando, mata o macho e, com isso, consegue ser novamente transformado em homem pelos deuses. Por ter experimentado tanto o prazer sexual feminino quanto o masculino, Tirésias é escolhido como juiz em uma disputa entre Zeus e Hera com relação a esse tema. Ao afirmar no veredito que o prazer da mulher era superior ao do homem, na proporção de nove a um, a deusa o cega, pois apesar de aparentemente dar a vitória às mulheres, sua conclusão privilegiava os homens, na medida em que o prazer feminino dependeria do desempenho masculino (BRANDÃO, 1997). Zeus, condoído, dá-lhe o dom da adivinhação como forma de "ver o futuro". Tal dom desempenhará papel especial em outros mitos como, por exemplo, o de Édipo.

Já no reino da Frígia (atualmente região da Turquia), os sacerdotes do deus Atis - filho e amante de Cibele, a mãe Terra - eram obrigados a se castrar em deferência a Atis, que se emasculou sob um pinheiro por conta desse amor proibido, mas realizado. Esses sacerdotes não só se castravam, mas também podiam retirar toda a genitália externa masculina. Viviam e se vestiam como mulheres comuns. O culto foi levado a Roma após as Guerras Púnicas travadas contra Cartago nos séculos III e II a.C., onde, apesar de proibido, era valorizado. Para homenagear esse amor entre mãe e filho, os iniciados no culto de Cibele dançavam em frenesi no Dia do Sangue. Os 
sacerdotes do culto atravessavam as ruas de Roma, extirpavam seus testículos com uma faca de pedra consagrada e depois jogavam as partes ensangüentadas na casa de um romano fora de suspeita. Os moradores afortunados dessa casa deveriam dar roupas de mulher ao sacerdote, que as vestiria até o final de sua vida. Conhecidos como galli, esses eunucos vestidos de mulher tomavam conta do templo de Cibele, que permaneceu até o século IV d.C. no sítio romano hoje ocupado pela basílica de São Pedro (FRIEDMAN, 2002).

Os gregos possuíam ainda um deus chamado Hermafrodita, que era o patrono da união sexual. Filho de Hermes e Afrodite, possuía mamas e pênis. Conforme estátuas e representações no Museu do Louvre e outros museus, ele lembra muito os atuais travestis ou transexuais, tanto em forma física como em postura: masculina e feminina ao mesmo tempo.

Outra referência mitológica remete a uma tribo de Cítios - povo da Antiguidade - os Enarees, que foram punidos por Afrodite por terem saqueado seu templo mais antigo, em Ascelon. Foram transformados em mulheres assim como toda a sua descendência. Hipócrates, todavia, via a feminilização dos Enarees como resultado de intensas e constantes cavalgadas que afetariam sua masculinidade por alguma forma de lesão física (NEW, KITZINGER, 1993; GREEN, 1998; VON KRAFFT-EBING, 1999).

BRANDÃO (1997) relata que o transvestismo e a androgenia estão intimamente relacionados ao casamento do herói grego. São vários os heróis que mudam de sexo: Ceneu, Ífis, Leucipo eram mulheres que foram 
transformadas em homens na época do casamento; Himeneu, Cécrops, Átamas, por sua vez, eram homens e se transformaram em mulheres também na época do casamento. $O$ autor sugere que o casamento do herói seria uma forma de restituição de um equilíbrio perdido; retoma o mito andrógino narrado por Platão, por meio de Aristófanes, no livro "O Banquete", no qual todo ser humano era composto de duas partes, ou homem ou mulher, que teriam sido separadas por decisão divina. Dessa forma, desde então todos buscam a metade perdida (homem ou mulher), a "alma gêmea".

Não apenas na mitologia greco-romana a mudança de gênero encontra-se presente. No livro hindu Mahabharata, é descrita a história de um rei que se transformou em mulher após se banhar em um rio mágico. Teve centenas de filhos e quando foi-Ihe oferecida a oportunidade de ser novamente transformado em homem, recusou, pois dizia a quem quisesse ouvir que o prazer da mulher é muito maior do que o do homem. Ao contrário do mito grego de Tirésias, sua recusa foi aceita e ele viveu como mulher (GREEN, 1998).

Na Europa Ocidental, em plena Idade Média, bruxas e demônios dominavam o cenário religioso e cotidiano. Em 1486, dois monges dominicanos, Heinrich Kramer e Jacobus Sprenger, publicam o Malleus Maleficarum, livro depois adotado pela Inquisição no qual relatam-se casos e tratamentos de bruxarias e possessões demoníacas (KRAMER, SPRENGER, 1973; GREEN, 1998). Interessante nessa obra, um homem nunca poderia ser transformado maleficamente em mulher, mas uma mulher 
poderia, sim, ser transformada em homem. Isso aconteceria pelo fato da natureza, na visão corrente à época, evoluir da mulher para o homem, sendo a mulher um homem pouco desenvolvido (LAQUEUR, 2001).

\section{$2.2 \quad$ Aspectos históricos}

Não existem referências disponíveis a respeito de homens vivendo como mulheres ou mulheres vivendo como homens antes do Império Romano.

Filo, filósofo judeu helenizado do século I d.C. e morador em Alexandria, segundo HYDE (1994) e GREEN (1998), descreve homens que se transvestem e vivem como mulheres, chegando até a se emascular e retirar o pênis. Seriam os chamados eunucos, termo que deriva da expressão grega para guardião ou zelador do leito. Aqueles que guardavam, sem riscos, os leitos das mulheres de seus senhores (FRIEDMAN, 2002).

GREEN (1998) cita as descrições e poemas feitos pelos romanos Manilus e Juvenal acerca desses indivíduos que viviam e se comportavam como mulheres e tinham vergonha e ódio de serem vistos como homens.

Esses eunucos, em Roma, tinham os testículos extirpados, mas muitas vezes mantinham seus pênis, o que lhes possibilitava ereções. Alguns, todavia, tinham os testículos e pênis removidos.

Vários imperadores romanos são descritos por se transvestirem ou apresentarem características afeminadas. Contudo, dois casos merecem 
destaque. O primeiro diz respeito a Nero que após chutar sua esposa grávida, Poppaea, até a morte, arrependeu-se e, tomado de remorsos, buscou alguém parecido com ela. Encontrou em um escravo, Sporus, essa semelhança. Nero então ordenou a seus cirurgiões que o transformassem em mulher. Após a cirurgia os dois se casaram formalmente - inclusive com direito a véu de noiva e enxoval - e Sporus viveu como mulher a partir de então (GREGERSEN, 1983; GREEN, 1998).

Já o imperador romano Heliogábalo casou-se formalmente com um poderoso escravo, adotou o papel de esposa e oferecia metade de seu império ao médico que o equipasse com uma genitália feminina (GREEN, 1998).

No século IX, lenda ou não, teria existido o Papa João VIII nomeado em 855 sucessor do Papa Leão IV. Na verdade, seria uma mulher transvestida de homem que teria engravidado e morrido ao dar à luz um bebê (GREEN,1998). Segundo NEW e KITZINGER (1993), a Papisa Joana teria nascido mulher com o possível nome de Giliberta, e adotou o nome masculino de "John Anglicus" e foi papa por 2 anos, 7 meses e 4 dias. As autoras especulam que o Papa João VIII poderia ter realmente sido uma mulher com deficiência de 21 - hidroxilase, ou seja, uma pseudohermafrodita feminina. De qualquer maneira, a história alcançou nossos dias e transformou-se em filme de Michael Anderson chamado "Pope Joan", com Liv Ullmann no papel principal.

Há referências até no meio médico de que nessa época da História existiam pessoas de um gênero que se passavam e viviam como se 
pertencendo ao gênero que não o de seu nascimento. A maior autoridade em ginecologia medieval e do renascimento teria sido Trotula, mulher formada na Escola de Medicina de Salerno que teria escrito por volta de 1150 d.C. os mais populares tratados de cosmetologia e saúde de mulheres. $\mathrm{Na}$ realidade, Trotula teria sido um homem que se transvestia de mulher para tratar de mulheres. Essa seria sua única opção, pois era então proibido um homem cuidar de uma mulher no papel de médico (NEW, KITZINGER, 1993).

Já na Renascença, o Rei Henrique III de França, "Sa Majeste" - que significa Sua Majestade, mas no feminino - queria ser considerado mulher, tendo se apresentado aos deputados transvestido, usando um longo colar de pérolas e um vestido curto (GREEN,1998).

Durante o século XVII, na França, o abade de Choisy, também conhecido como François Timoleon, após ter sido criado como menina por sua mãe, deixou um vívido relato de seu desejo de ser e de se vestir como mulher (GREEN, 1998).

Um dos mais famosos personagens de "cross-gender" é o Chevalier d'Eon, que deu origem ao epônimo "eonismo" para significar o fenômeno do transvestismo em linhas gerais. Ele era o rival de Madame de Pompadour como amante de Luis XV. Quando o rei descobriu seu erro de avaliação, nomeou-o embaixador. Quando Luis XV faleceu, ele viveu permanentemente como mulher. Passou seus últimos anos na Inglaterra e viveu 49 anos como homem e 34 como mulher (GREEN, 1998). 
Em Versalhes, em 1858, Mlle. Jenny Savalette de Lange revelou, ao morrer, se tratar de um homem. Passou toda a vida como mulher, tendo se relacionado com seis homens; tinha certidão de nascimento falsa e recebia do rei uma pensão e moradia em Versalhes (GREEN, 1998).

Não apenas na França esse fenômeno se manifestava. Nos Estados Unidos da América do Norte, é famoso Lorde Cornbury, primeiro governador colonial de Nova York, que chegou ao Novo Mundo vestido como mulher e despachava assim em seu escritório. Cem anos depois, durante a Guerra de Secessão, Mary Walker foi a primeira mulher a ser comissionada como cirurgiã do exército e a ser autorizada pelo Congresso a se vestir com roupas de homens (GREEN, 1998).

\subsection{Elementos transculturais}

Relatos etnográficos do mundo todo revelam fenômenos de mudança de gênero em muitas culturas e povos.

Várias tribos de índios norte-americanos têm relatos ou entendimentos míticos ou culturais de mudança de gênero (HYDE, 1994; GREEN, 1998).

Os mais famosos são os Yuman, que acreditam numa "mudança de espírito" após determinados sonhos que aconteceriam na puberdade. Nesses sonhos, jovens homens sonhariam que seriam mulheres e passariam a adotar a postura e os trejeitos femininos, sendo chamados de 
elxa. O contraponto feminino também ocorre e é chamado de kwe'rhame. Eles são aceitos pela tribo e passam a desempenhar os papéis do gênero atribuído e não mais os do gênero de nascimento. Entre os Yuman da Sierra Estrella acredita-se que a montanha tenha o poder de transformar o sexo dos meninos que desde cedo mostrariam essa mudança. Seriam os Berdache, homens que vivem como mulheres e são aceitos como tal. $\mathrm{O}$ contrário, mulheres que vivem como homens, também existe e é aceito (GREEN, 1998). Isto revela uma aprovação social que permite a mudança de gênero (KESSLER, MCKENNA, 1978)

O termo berdache foi primeiramente utilizado pelos exploradores franceses da América para descrever os indígenas norte-americanos homossexuais passivos, isto é, aqueles nativos que mantinham relações sexuais com outros do mesmo sexo e eram penetrados por esses. Isto gerou a confusão e sinonímia entre homossexualidade e transvestismo com o fenômeno de mudança de gênero. Aliás, a palavra berdache deriva do francês "bardash" que, por sua vez, é derivado do termo italiano " berdascia", com origem no árabe "bardaji", variação do persa "barah", que significa escravo, michê ou prostituto (KESSLER, MCKENNA, 1978).

Outras tribos são descritas como os Cocopa, os Mojave, Navajo, Jukis e Pueblo, tendo e aceitando os mesmos comportamentos (GREEN, 1998).

O mesmo fenômeno se repete entre outros povos, desde tribos siberianas, africanas, brasileiras, da Patagônia e, inclusive, da Oceania (GREEN, 1998). 
Entre os indianos da cidade de Varanasi, ao norte da Índia, rituais de castração ou de se vestir como mulher é aceito e explicado culturalmente, como entre os hijras e os jankhas (COHEN, 1995).

Segundo MONEY (1988), os hijras podem ser considerados tanto indivíduos pertencentes a uma casta quanto a um culto. Possuem uma deusa própria, Bahuchara Mata e pela medicina ocidental podem ser considerados transexuais masculinos.

\subsection{Do século XIX aos nossos dias: a visão científica}

Os primeiros trabalhos sobre sexualidade surgiram no século XIX, nos países de língua alemã. A homossexualidade foi um dos primeiros fenômenos com os quais os pioneiros em sexologia tentaram a formulação de teorias de entendimento e explicação, mais sob uma perspectiva médica do que moral (PERSON, 1999).

Carl Heinrich Ulrichs, nascido em 1862 e falecido em 1895, era um advogado e homossexual que propôs a teoria de que o homossexual não seria nem criminoso nem insano, mas uma "alma feminina num corpo masculino", resultado de um erro na diferenciação embrionária (HAUSSMAN, 1995; PERSON, 1999).

Richard Von Krafft-Ebing, nascido em 1840 e falecido em 1902, influenciado por Ulrichs, publicou em 1886 Psychopathia Sexualis e marca o início de um estudo médico organizado a respeito da sexualidade humana. 
Antes dele outros autores já haviam se manifestado em relação ao tema ( H.J. Löwenstein em 1823, Joseph Häussler em 1826 e Heinrich Kaan em 1844), mas este livro-texto tornou-se um marco na história da assim chamada Sexologia (KING, 1999; PERSON, 1999).

No capítulo 4 do livro, intitulado "Patologia geral: neurológica e psicológica", o autor apresenta um "esquema das neuroses sexuais":

Periféricas:

Sensorias:

1. anestesia;

2. hiperestesia;

3. neuralgia.

Secretórias:

4. aspermia;

5. polispermia.

Motoras:

6. poluções (espasmos);

7. espermatorréia (paralisia).

Neuroses Espinais:

Afecções do centro de ereção:

1. irritação;

2. paralisias;

3. inibição;

4. fraqueza irritável. 
- Afecções do centro ejaculatório:

1. ejaculação precoce anormal;

2. ejaculação retardada anormal.

- Neuroses cerebrais:

1. paradoxia;

2. anestesia;

3. hiperestesia;

4. parestesia: sadismo, masoquismo, fetichismo e sexualidade antipática.

Toda esta divisão representa uma forma de pensar relacionada aos conceitos e padrões alemães da época em relação à sexualidade e à medicina em linhas gerais.

Cabe maior detalhamento ao item sexualidade antipática dentro dessa classificação, pelo significado e pela importância no estudo de transtornos de identidade de gênero.

VON KRAFFT-EBING (1999, p.58) define sexualidade antipática como:

a total falta de sentimento sexual pelo sexo oposto. Concentrase toda a sexualidade em seu próprio sexo. Só as propriedades físicas e psíquicas de pessoas do mesmo sexo produzem efeito afrodisíaco e despertam desejo de união sexual. Isto é uma anomalia puramente psíquica, na qual o instinto sexual não corresponde de nenhuma maneira às características sexuais primárias e secundárias. Em detrimento 
da diferenciação sexual total e do desenvolvimento e atividade normal das glândulas sexuais, o homem é dirigido sexualmente a outro homem, por que conscientemente ou qualquer que seja o motivo ele tem instintos de fêmea.

Essa entidade clínica teria variados graus de desenvolvimento e "afetaria pessoas sem doenças mentais" ( VON KRAFFT-EBING, 1999).

Pesando as influências dos fatores biológicos associados aos fatores educacionais e ambientais, VON KRAFFT-EBING (1999) propõe que características psicossexuais da personalidade se desenvolvem e se tornam imutáveis. Essas características, se não sofrem influências adversas, tornam-se tão harmoniosas e completamente relacionadas com o sexo do indivíduo que mesmo a perda de órgãos, senilidade ou a menopausa não podem alterá-las.

Pode-se entender que as características psicossexuais, das quais fala Von Krafft-Ebing, podem ter conexão com o conceito moderno de identidade sexual.

Esse mesmo autor postula que se o desenvolvimento dessas características for alterado, a personalidade psicossexual poderá ter uma constituição anormal. Concebe-se uma alteração funcional e anatômica, apesar de ser ela desconhecida.

Essa sexualidade invertida aparece espontaneamente, sem causas externas, com o desenvolvimento da vida sexual, como manifestação individual de uma forma de vida sexual anormal e tem a força de um fenômeno congênito; ou se desenvolve 
como uma sexualidade que no início era normal, mas que, como o resultado de influências danosas, se comporta como anomalia adquirida (VON KRAFFT-EBING, 1999, p.288).

Ele ainda descreve os graus de manifestação da assim chamada sexualidade antipática, de sentimentos e instintos homossexuais, passando por alterações da "personalidade psíquica", com a correspondente "inversão sexual" até a busca de transformação corporal para o sexo desejado. Essa distinção por graus é dissecada em casos clínicos descritos e discutidos na obra Psychopathia Sexualis.

É interessante notar que a homossexualidade e as questões de identidade sexual estavam colocadas juntas, mas diferenciadas por graus de comprometimento da personalidade.

Já em pleno século XX, Magnus Hirschfeld (nascido em 1868 e falecido em 1935, sob o regime nazista), médico, judeu-alemão e homossexual assumido, publica em 1910 o livro Die Transvestiten em alemão, traduzido para o inglês como Transvestites e sem tradução para o português.

Hirschfeld funda em Berlim o primeiro instituto devotado à pesquisa e ao estudo da sexualidade, fechado com a ascensão de Hitler, que também queimou publicamente sua biblioteca (DOCTER, 1990).

Antes dele, Carl von Westphal, professor de Psiquiatria em Berlim, publicou a história de uma mulher e de um homem que se vestiam em gêneros trocados desde a infância. Ele chamou o fenômeno de "sentimentos sexuais contrários". Todavia, foi Hirschfeld quem publicou extenso trabalho 
médico com descrição de casos clínicos e cunhou o termo "travestis" para descrever as pessoas que sentem necessidade de vestir roupas do sexo oposto (BULLOUGH, 1991).

No livro, Hirschfeld utiliza os termos pederastia, uranismo e homossexualismo como sinônimos. Na virada do século XIX para o século $\mathrm{XX}$, os três termos referiam-se ao mesmo fenômeno. Porém, existe uma grande distinção. Pederastia é descrita como o amor de um homem adulto por um pré-púbere do sexo masculino. Karl Heinrich Ulrichs cunhou o termo uranismo e Karoly Maria Benkert inventou o termo homossexual em 1869, segundo Michael Lombardi-Nash, tradutor para o inglês do livro de Hirschfeld, em 1991.

Não obstante a confusão de termos, Hirschfeld é um dos pioneiros no uso do termo transexual. Ele se refere a um de seus pacientes como sendo transexual psíquico (HIRSCHFELD, 1991; BULLOUGH e BULLOUGH, 1998).

Uma pausa porém se faz necessária para a origem do termo "uranismo". Segundo VON KRAFFT-EBING (1999), a origem da expressão encontra-se em Platão, no livro "O Banquete", no discurso de Pausânias, contado por Aristodemo. No discurso a respeito do Amor (ou Eros), comenta-se que sem Amor não existe Afrodite. E como são duas Afrodites as existentes, seriam dois os Amores correspondentes.

Uma, a mais velha sem dúvida, não tem mãe e é filha de Urano, e a ela chamamos de Urânia, a Celestial; a mais nova, filha de Zeus e de Dione, chamamo-la de Pandêmia, a Popular. 
É forçoso então que também o Amor, coadjuvante de uma se chame corretamente Pandêmio, o Popular, e o outro Urânio, o Celestial. (PLATÃO, 1997, p. 107).

Seria o Amor Urânio o dedicado aos homens jovens e não às mulheres. Daí a origem do termo uranismo adotado por Ulrichs para designar o desejo de um homem por outro.

Já MONEY (1988) refere que a origem do termo uranismo está no livro Argonauticus de Karl Heinrich Ulrichs, publicado em Leipzig em 1869. Emprestando de Platão, que no livro Symposium fala de Urânia, filha de Urano, concebida sem uma mãe, Ulrichs cunha o termo uranismo e o aplica àqueles homens que, como as mulheres, sentem repulsa pelas mulheres e atração pelos homens porque têm, na verdade, mente feminina em corpo masculino.

Ainda em seu livro, HIRSCHFELD (1991) relaciona vários casos de homens e mulheres que se transvestem e discute as variações e motivações desses casos, identificando 10 variedades de transvestismo que foram relacionadas com padrões de comportamentos atuais por DOCTER (1990):

1. Travesti completo: transveste-se e deseja a cirurgia de redesignação sexual. Corresponderia à denominação atual de transexualismo;

2. Travesti parcial: Sente-se satisfeito com o transvestismo e não deseja a cirurgia. Encaixa-se na denominação de travesti;

3. Travesti constante: A descrição de Hirschfeld é similar à denominação de transgênero; 
4. Travesti periódico: Encaixa-se na atual denominação de travesti. Aspectos fetichistas são reconhecíveis e a periodicidade é utilizada na diferenciação com o transexualismo;

5. Travesti no nome: A adoção de um nome feminino faz parte da evolução do transvestismo e acontece após anos da prática de se vestir com as roupas do gênero oposto. Essa é uma categoria que não se faz necessária;

6. Travesti narcísico: características de personalidade narcísica são comuns entre os travestis, mas é desnecessário subtipo específico;

7. Travesti homossexual: Esta categoria de Hirschfeld pode ser enquadrada dentro do transexualismo. Travestis homossexuais e não transexuais são comuns, mas formam uma população pouco estudada pela ciência;

8. Travesti bissexual: Assim como a categoria anterior, os chamados travestis bissexuais são pouco estudados. Deve haver parte considerável de bissexuais entre os chamados travestis heterossexuais;

9. Travesti metatrópico: Seriam aqueles que buscam o amor em uma mulher masculinizada. Não se configura como classificação útil;

10. Travesti autônomo-sexual: Inclui aqueles indivíduos cuja vida sexual é isolada e centrada na própria imagem, "a linda mulher 
no espelho". Apesar de ser característica comum, não se sustenta como categoria específica.

Outros autores também no estudo da sexualidade humana, publicam trabalhos e se interessam por esse aspecto. $O$ inglês Henry Havelock Ellis, nascido em 1859 e falecido em 1939, tem sido descrito como um dos primeiros e maiores incentivadores de todas as práticas sexuais. Ele decidiu cedo na vida devotar-se aos estudos da sexualidade, para evitar, às futuras gerações, os problemas e perplexidades que a ignorância haviam lhe causado (PERSON, 1999).

Em 1936, Havelock Ellis cunha os termos "inversão sexoestética" e "eonismo" (em homenagem ao já descrito Chevalier d’Eon) para descrever o fenômeno do transvestismo (ELLIS, 1936).

É da década de 20 que surgem os primeiros relatos de cirurgia para mudança de sexo. Os primórdios da cirurgia se situam no tratamento para pseudo-hermafroditas e hermafroditas verdadeiros com as chamadas cirurgias de adequação sexual. Experiências com o que atualmente chamam de transexualismo foram feitas na Alemanha, como a do pintor Einar Wegener que em 1923, aos 40 anos, retirou os testículos e o pênis. Posteriormente adotou nacionalidade dinamarquesa e se tornou Lili Elbe (DOCTER, 1990). E é também na Dinamarca que se registraram cirurgias bem sucedidas como a de Robert Cowell, aviador da Segunda Guerra Mundial, que se tornou Roberta Cowell, mas sem notoriedade e divulgação (BULLOUGH, BULLOUGH, 1998). 
Alfred Kinsey, nascido em 1894 e falecido em 1956, biólogo que se tornou sexologista, inicia em 1938 um amplo estudo que documenta "quem faz o quê, onde e com quem", em termos sexuais. Em relação à homossexualidade, revela ao público que $4 \%$ da população masculina era exclusivamente homossexual; $37 \%$ dos homens adultos haviam experimentado o orgasmo em uma experiência homossexual na adolescência e 50\% já havia respondido a estímulos homoeróticos. Além disso, afirma que a prática do comportamento homossexual é amplamente difundida na sociedade, que torna impossível restringi-la a uma minoria desviante. Ele cria a famosa Escala Kinsey que avalia as pessoas numa progressão homossexual-heterossexual de sete pontos, de zero (completamente heterossexual) até seis (completamente homossexual), retirando a homossexualidade da anormalidade e colocando-a num "continuum" de comportamentos sexuais aceitos (PERSON, 1999).

Em 1949, David O. Cauldwell utiliza o termo "psicopatia transexual", mais tarde referido como "transexualismo", para descrever o mais extremo exemplo de desconforto de gênero de uma garota que queria ser homem (GREGERSEN, 1982; BULLOUGH，BULLOUGH，1998; PAULY，1998; FERREIRA, 2000).

Mas é em 1952, com a divulgação em um jornal norte-americano da história de Christine Jorgensen, nascida George Jorgensen, que as questões de identidade sexual ganham conhecimento público.

George Jorgensen Jr nasceu no "Memorial Day" de 1926 em Manhattan. Filho de descendentes de escandinavos, era um garoto quieto, 
tranqüilo e com maneiras femininas, que aos 19 anos, em outubro de 1945, ingressou nas Forças Armadas Americanas, sendo dispensado com honra 6 meses depois por uma pneumonia. Durante seu período nas Forças Armadas, percebeu que sentia atração pelos colegas e não por mulheres. E o mais relevante, seu interesse não era de um homossexual por um homem, mas sim de uma mulher por um homem.

Nessa época tornou-se fotógrafo e sonhava em trabalhar em Hollywood. Inteirou-se sobre as recentes experiências com hormônios femininos feitas na Dinamarca e em pouco tempo se encontrava em Copenhague frente ao endocrinologista, Dr. Christian Hamburger, solicitando ajuda. Graças ao Ato Dinamarquês de Esterilização e Castração de 1935 (que permitia a castração quando a sexualidade do paciente induzia-o a cometer crimes ou quando envolvia distúrbios mentais com acentuada gravidade), Jorgensen conseguiu não só utilizar hormônios mas também realizar duas cirurgias em dois tempos distintos. A primeira retirou seus testículos e a segunda, em 1952, seu pênis. Ninguém na época pensou na construção de uma vagina. Desde sua primeira cirurgia e concomitante uso de hormônios, ele começou a se vestir como mulher, utilizar nome feminino e viver como se fosse uma mulher.

Em dezembro de 1952, ao regressar aos Estados Unidos, foi primeira página de vários jornais norte-americanos: "Ex-GI becomes blonde Beauty" ("New York Daily News", 1ํ de dezembro de 1952) e "Dear Mum and Dad, son wrote, I've now become your daughter" ("The Daily Mirror", 2 de dezembro de 1952). Em 1967 escreveu sua biografia. Nunca se casou nem 
teve amantes. Virou tema de filme em 1985, "What Sex Am I?". Foi perseguida por pregadores religiosos, políticos e moralistas em geral. Bebeu muito e morreu em 1989 (BULLOUGH, BULLOUGH, 1998; DENNY, 1998).

É, no entanto, na década de 60 que as questões ligadas ao transexualismo saem da mídia e ganham o terreno da medicina, com a participação do Dr. Harry Benjamin.

Segundo PERSON (1999, p. 361), “Harry Benjamin descobriu a síndrome que nós chamamos de transexualismo, nomeou-a, ajudou a projetar o tratamento e mergulhou intensamente em seu estudo e manejo".

Aos quase 70 anos recebeu de seu amigo Alfred Kinsey um paciente que dizia ser uma mulher presa em corpo de homem. Diferente de todos os outros pacientes que já havia visto - homossexuais "crossdressers" chamados de "drag queens" ou heterossexuais "cross-dressers" chamados de travestis -, que se identificavam como homens, este se identificava como mulher e vivia como mulher. Ele não era delirante nem tinha qualquer psicopatologia psicótica. Ao saber do caso Jorgensen, fez uma correlação que se tornou prática e famosa no seguimento de transexuais (PERSON, 1999).

A história desse pesquisador é interessante.

Harry Benjamin nasceu em Berlim em 1884, filho de um judeu alemão e de uma luterana anti-semita e anti-católica.

Após ter-se formado em medicina, interessou-se pelo trabalho com tuberculose e foi por meio desse interesse que em 1913 chegou aos Estados Unidos a convite de um banqueiro novaiorquino, acompanhando seu mestre 
F.F. Friedmann, que teria cura e vacina fabulosas para a tuberculose. Após ser descoberta como fraude, Benjamin rompeu com Friedmann que negouse a pagar sua passagem de volta para a Alemanha.

Em Nova York começou a trabalhar no campo da Endocrinologia. Existe um acontecimento interessante que correlaciona Benjamin a Freud. Eles teriam se encontrado entre 1928 e 1930. Após uma conversa, em clima pouco amigável, Freud teria feito um comentário de que Benjamin seria um homossexual latente por causa de uma impotência psicogênica que o acometia em relação à esposa. Depois disso, Benjamin, que já não via a Psicanálise com bons olhos, passou a considerá-la como não-científica (REPPEN, 1998; PERSON, 1999).

Seu trabalho com transexuais culminou com a publicação em 1966 do livro "The Transsexual Phenomenon", no qual expõe suas idéias a respeito dessa "síndrome". O livro foi considerado pornográfico, quando de seu lançamento (PERSON, 1999).

Segundo MONEY (1988), foi Harry Benjamin quem tornou o termo popular e acrescentou um segundo "s" ao termo inglês, transexual, já existente.

Benjamin estabeleceu uma escala de orientação sexual chamada "Harry Benjamin Sex Orientation Scale (S.O.S.), Sex and Gender Disorientation and Indecision (Males)" - Escala Harry Benjamin de Orientação Sexual, Desorientação e Indecisão de Sexo e Gênero (Homens) - baseada em sua percepção desses indivíduos, na qual descreve tipos, diferenciando transvestismo de transexualismo. 
Esta tipologia serve como guia diagnóstico, muito parecida com as classificações propostas por Krafft-Ebing, Hirschfeld e Ellis, mas não serve como definição diagnóstica.

Avanços importantes são a exclusão da homossexualidade e a diferenciação entre transvestismo e transexualismo (BENJAMIN, 1966).

Essa classificação de 1966 encontra-se hoje disponível e acessível à população via internet em vários "sites" relacionados a transexualismo e ao autor www.overtherainbow.org.com www.twentyclub.org www.genderpsychology.org www.translife.net www.symposion.com.

A Tabela 1 apresenta essa classificação para melhor entendimento das idéias do autor. 
Tabela 1 - Desorientação e indecisão de sexo e gênero (homens) - Harry Benjamin - 1966

\begin{tabular}{|c|c|c|}
\hline & $\begin{array}{c}\text { TIPO I } \\
\text { PSEUDO -TRAVESTI }\end{array}$ & $\begin{array}{c}\text { TIPO II } \\
\text { TRAVESTI } \\
\text { FETICHISTA }\end{array}$ \\
\hline $\begin{array}{c}\text { SENTIMENTO QUANTO } \\
\text { AO GÊNERO }\end{array}$ & Masculino & Masculino \\
\hline $\begin{array}{c}\text { HÁBITOS DE SE } \\
\text { VESTIR E VIDA SOCIAL }\end{array}$ & $\begin{array}{l}\text { Vida masculina normal. } \\
\text { Pode apresentar } \\
\text { pequeno desejo de se } \\
\text { vestir. Não é } \\
\text { verdadeiramente } \\
\text { transexual. }\end{array}$ & $\begin{array}{l}\text { Vive como homem. } \\
\text { Veste-se } \\
\text { periodicamente ou em } \\
\text { parte do tempo. Veste- } \\
\text { se com roupas } \\
\text { masculinas.. }\end{array}$ \\
\hline $\begin{array}{l}\text { OBJETO DE ESCOLHA } \\
\text { SEXUAL E VIDA } \\
\text { SEXUAL }\end{array}$ & $\begin{array}{c}\text { Usualmente } \\
\text { heterossexual. } \\
\text { Raramente bissexual. } \\
\text { Masturba-se com } \\
\text { fetiches. Apresenta } \\
\text { sentimentos de culpa. } \\
\text { Penaliza-se e relaxa. }\end{array}$ & $\begin{array}{c}\text { Usualmente } \\
\text { heterossexual. Pode } \\
\text { ser bi ou homossexual. } \\
\text { Principalmente durante } \\
\text { a masturbação tem } \\
\text { fantasias de se vestir e } \\
\text { de mudança de sexo. }\end{array}$ \\
\hline $\begin{array}{l}\text { OPERAÇÃO DE } \\
\text { CONVERSÃO }\end{array}$ & $\begin{array}{l}\text { Na realidade não } \\
\text { considera. }\end{array}$ & $\begin{array}{c}\text { Pode considerar } \\
\text { somente em fantasia. } \\
\text { Rejeita-a }\end{array}$ \\
\hline $\begin{array}{l}\text { HORMONIOTERAPIA / } \\
\text { ESTROGENOTERAPIA }\end{array}$ & $\begin{array}{l}\text { Não considera; não } \\
\text { indicada }\end{array}$ & $\begin{array}{c}\text { Raramente } \\
\text { interessado. Pode } \\
\text { ajudar a reduzir a } \\
\text { libido. }\end{array}$ \\
\hline PSICOTERAPIA & $\begin{array}{l}\text { Paciente não deseja. } \\
\text { Desnecessária }\end{array}$ & $\begin{array}{c}\text { Pode ser bem sucedida } \\
\text { em circunstância social } \\
\text { favorável. }\end{array}$ \\
\hline OBSERVAÇÕES & $\begin{array}{c}\text { Somente interesse } \\
\text { esporádico em se } \\
\text { vestir. Raramente tem } \\
\text { nome feminino quando } \\
\text { vestido. }\end{array}$ & $\begin{array}{c}\text { Pode ser confundida } \\
\text { com dupla } \\
\text { personalidade } \\
\text { masculina e feminina, } \\
\text { com nomes masculinos } \\
\text { e femininos. }\end{array}$ \\
\hline
\end{tabular}

Tipo 0: Orientação e identificação sexuais sem problemas: heterossexual, homossexual ou bissexual. As idéias de "vestir" ou "mudar de sexo" são estranhas e desprazerosas. Inclui a maioria das pessoas. 
Tabela 1 - Desorientação e indecisão de sexo e gênero (homens) - Harry Benjamin - 1966

\begin{tabular}{|c|c|c|}
\hline & \multicolumn{2}{|r|}{ continuação } \\
\hline & $\begin{array}{c}\text { TIPO III } \\
\text { TRAVESTI } \\
\text { VERDADEIRO }\end{array}$ & $\begin{array}{c}\text { TIPO IV } \\
\text { TRANSEXUAL } \\
\text { NÃO-CIRÚRGICO }\end{array}$ \\
\hline $\begin{array}{c}\text { SENTIMENTO QUANTO } \\
\text { AO GÊNERO }\end{array}$ & $\begin{array}{l}\text { Masculino, mas sem } \\
\text { convicção. }\end{array}$ & $\begin{array}{l}\text { Incerto entre travesti e } \\
\text { transexual. Pode } \\
\text { rejeitar seu gênero. }\end{array}$ \\
\hline $\begin{array}{c}\text { HÁBITOS DE SE } \\
\text { VESTIR E VIDA SOCIAL }\end{array}$ & $\begin{array}{c}\text { Veste-se } \\
\text { constantemente ou } \\
\text { com a freqüência } \\
\text { possível. Pode viver e } \\
\text { ser aceito como } \\
\text { mulher. Pode se vestir } \\
\text { com roupas } \\
\text { masculinas. }\end{array}$ & $\begin{array}{l}\text { Veste-se sempre que } \\
\text { possível com } \\
\text { insuficiente alívio do } \\
\text { desconforto de gênero. } \\
\text { Pode viver como } \\
\text { homem ou mulher. }\end{array}$ \\
\hline $\begin{array}{c}\text { OBJETO DE ESCOLHA } \\
\text { SEXUAL E VIDA } \\
\text { SEXUAL }\end{array}$ & $\begin{array}{l}\text { Heterossexual, exceto } \\
\text { quando vestido. Vestir } \\
\text { dá satisfação sexual e } \\
\text { alívio ao desconforto de } \\
\text { gênero. Comum a } \\
\text { punição e o } \\
\text { relaxamento. }\end{array}$ & $\begin{array}{l}\text { Baixa libido. } \\
\text { Geralmente assexual } \\
\text { ou auto-erótico. Pode } \\
\text { ser bissexual. }\end{array}$ \\
\hline $\begin{array}{c}\text { OPERAÇÃO DE } \\
\text { CONVERSÃO }\end{array}$ & $\begin{array}{c}\text { Rejeita, mas a idéia é } \\
\text { atraente. }\end{array}$ & $\begin{array}{l}\text { Atraente, mas não } \\
\text { solicitada. }\end{array}$ \\
\hline $\begin{array}{l}\text { HORMONIOTERAPIA / } \\
\text { ESTROGENOTERAPIA }\end{array}$ & $\begin{array}{l}\text { Atrativa como } \\
\text { experiência. Pode ser } \\
\text { útil como diagnóstico. }\end{array}$ & $\begin{array}{l}\text { Necessária para } \\
\text { conforto e balanço } \\
\text { emocional. }\end{array}$ \\
\hline PSICOTERAPIA & $\begin{array}{l}\text { Vale como tentativa, } \\
\text { mas sem sucesso de } \\
\text { cura. }\end{array}$ & $\begin{array}{c}\text { Só como apoio. Muitas } \\
\text { vezes recusada e sem } \\
\text { sucesso. }\end{array}$ \\
\hline OBSERVAÇÕES & $\begin{array}{l}\text { Pode assumir dupla } \\
\text { personalidade. Inclina- } \\
\text { se para o } \\
\text { transexualismo. }\end{array}$ & $\begin{array}{l}\text { Vida social dependente } \\
\text { das circunstâncias. } \\
\text { Freqüentemente } \\
\text { identifica-se como } \\
\text { transgênero. }\end{array}$ \\
\hline
\end{tabular}


Tabela 1 - Desorientação e indecisão de sexo e gênero (homens) - Harry Benjamin - 1966

\begin{tabular}{|c|c|c|}
\hline & \multicolumn{2}{|r|}{ conclusão } \\
\hline & $\begin{array}{c}\text { TIPO V } \\
\text { TRANSEXUAL } \\
\text { MODERADA } \\
\text { INTENSIDADE }\end{array}$ & $\begin{array}{c}\text { TIPO VI } \\
\text { TRANSEXUAL } \\
\text { ALTA INTENSIDADE }\end{array}$ \\
\hline $\begin{array}{c}\text { SENTIMENTO QUANTO } \\
\text { AO GÊNERO }\end{array}$ & $\begin{array}{l}\text { Feminino, preso em um } \\
\text { corpo masculino. }\end{array}$ & $\begin{array}{l}\text { Feminino, inversão } \\
\text { "psicossexual". }\end{array}$ \\
\hline $\begin{array}{c}\text { HÁBITOS DE SE } \\
\text { VESTIR E VIDA SOCIAL }\end{array}$ & $\begin{array}{c}\text { Vive e trabalha como } \\
\text { mulher, se possível. } \\
\text { Alívio insuficiente em } \\
\text { se vestir. }\end{array}$ & $\begin{array}{c}\text { Usualmente vive e } \\
\text { trabalha como mulher. } \\
\text { Sem nenhum alívio } \\
\text { com o vestir. } \\
\text { Desconforto de gênero } \\
\text { intenso. }\end{array}$ \\
\hline $\begin{array}{l}\text { OBJETO DE ESCOLHA } \\
\text { SEXUAL E VIDA } \\
\text { SEXUAL }\end{array}$ & $\begin{array}{l}\text { Baixa libido. Assexual, } \\
\text { auto-erótico ou } \\
\text { homossexualidade } \\
\text { passiva. Pode ter sido } \\
\text { casado e ter filhos. }\end{array}$ & $\begin{array}{c}\text { Desejos intensos de se } \\
\text { relacionar com homens } \\
\text { normais no papel de } \\
\text { mulher, se jovem. Com } \\
\text { o tempo, baixa libido. } \\
\text { Identificação } \\
\text { heterossexual, } \\
\text { bissexual ou lésbica. } \\
\text { Pode ter sido casado e } \\
\text { ter filhos. }\end{array}$ \\
\hline $\begin{array}{l}\text { OPERAÇÃO DE } \\
\text { CONVERSÃO }\end{array}$ & Solicitada. & $\begin{array}{l}\text { Urgentemente } \\
\text { solicitada e usualmente } \\
\text { conseguida. }\end{array}$ \\
\hline $\begin{array}{l}\text { HORMONIOTERAPIA / } \\
\text { ESTROGENOTERAPIA }\end{array}$ & $\begin{array}{c}\text { Necessária como } \\
\text { substituta ou como } \\
\text { preliminar para a } \\
\text { cirurgia de conversão } \\
\text { sexual. }\end{array}$ & $\begin{array}{l}\text { Necessária como alívio } \\
\text { parcial. }\end{array}$ \\
\hline PSICOTERAPIA & $\begin{array}{l}\text { Rejeitada. Menos ainda } \\
\text { como cura. Orientação } \\
\text { psicológica permissiva. }\end{array}$ & $\begin{array}{c}\text { Orientação psicológica } \\
\text { ou psicoterapia só } \\
\text { como alívio } \\
\text { sintomático. }\end{array}$ \\
\hline OBSERVAÇÕES & $\begin{array}{l}\text { Cirurgia desejada, } \\
\text { esperada e buscada } \\
\text { com esforço até } \\
\text { conseguir. }\end{array}$ & $\begin{array}{l}\text { Despreza seus órgãos } \\
\text { sexuais masculinos. } \\
\text { Perigo extremo de } \\
\text { auto-mutilação ou até } \\
\text { mesmo suicídio se a } \\
\text { cirurgia de conversão } \\
\text { não é conseguida. }\end{array}$ \\
\hline
\end{tabular}


Como explicitado nos vários tipos que descreve, Benjamin acreditava que o transexualismo seria só masculino. O transexualismo feminino seguiria outro desenvolvimento pelas suas características e freqüência na população (DENNY, 1998; PERSON, 1999). Ele acreditava em uma base biológica explicativa para ambos, mas misturada a fatores ambientais não explicitados (DENNY, 1998; PERSON, 1999).

Harry Benjamin trabalhou durante anos com transexuais. Atendeu milhares deles e morreu, em 1986, aos 102 anos de idade (PERSON, 1999).

Após Benjamin, a medicina dos Estados Unidos iniciou um processo de incorporação desse novo diagnóstico e o tratamento proposto pelo autor. O Johns Hopkins Hospital estabeleceu um Comitê Clínico de Identidade de Gênero e em 1960 o hospital realizou uma mamoplastia redutora bilateral em uma mulher que expressou o desejo de ser homem. Para participar desse mesmo processo, The Erikson Educational Foundation foi fundada no final da década de 60 com o intuito de disseminar o conhecimento e fomentar pesquisas nessa área, além de estimular a criação de clínicas de gênero (IRVINE, 1990).

Outro autor importante é John Money. Nascido em 1921 na Nova Zelândia, mudou-se aos 26 anos para os Estados Unidos (MONEY, 1988). Fez doutorado em psicologia na Universidade de Harvard com o tema de intersexo e depois foi para o Johns Hopkins Hospital, onde fez carreira meteórica como pesquisador e especialista em sexualidade (COLAPINTO, 2001). 
Em 1955, Money fez uma importante diferenciação entre sexo biológico e gênero a partir de seus primeiros estudos com intersexos (PERSON, 1999).

Provocador teórico desde os anos 60, Money estabeleceu uma teoria psicossocial de gênero e identidade, na qual toda criança deve ter sua identidade de gênero fixada muito cedo em sua vida (DREGER, 2000). Fundador da Clínica de Identidade de Gênero do Johns Hopkins Hospital, Money foi o reponsável por várias cirurgias de redesignação sexual realizadas com transexuais nas décadas de 60 e 70.

Money e seus associados demonstraram que o primeiro e crucial passo na diferenciação do gênero de uma criança é sua auto denominação como masculina ou feminina de acordo com o sexo atribuído e determinado. Na mesma época estabeleceram que a diferenciação de gênero, usualmente irreversível após os 18 meses de vida, está completa por volta dos 4,5 anos de idade (PERSON, 1999; BULLOUGH, 2003).

John Money escreve em 1973, com Anke Ehrhardt, sua colaboradora em muitos trabalhos, um livro que se torna peça fundamental no estudo de gênero, especialmente para os casos de intersexo e transexualismo. Trata-se de Man and woman, boy and girl. Nele, o autor explicita suas idéias a respeito da definição da identidade de gênero. A seqüência da diferenciação de gênero seria esquematicamente como demonstrado na Tabela 2. 
Tabela 2 - Definição de identidade de gênero

Money - 1994; Money, Ehrhardt - 1996

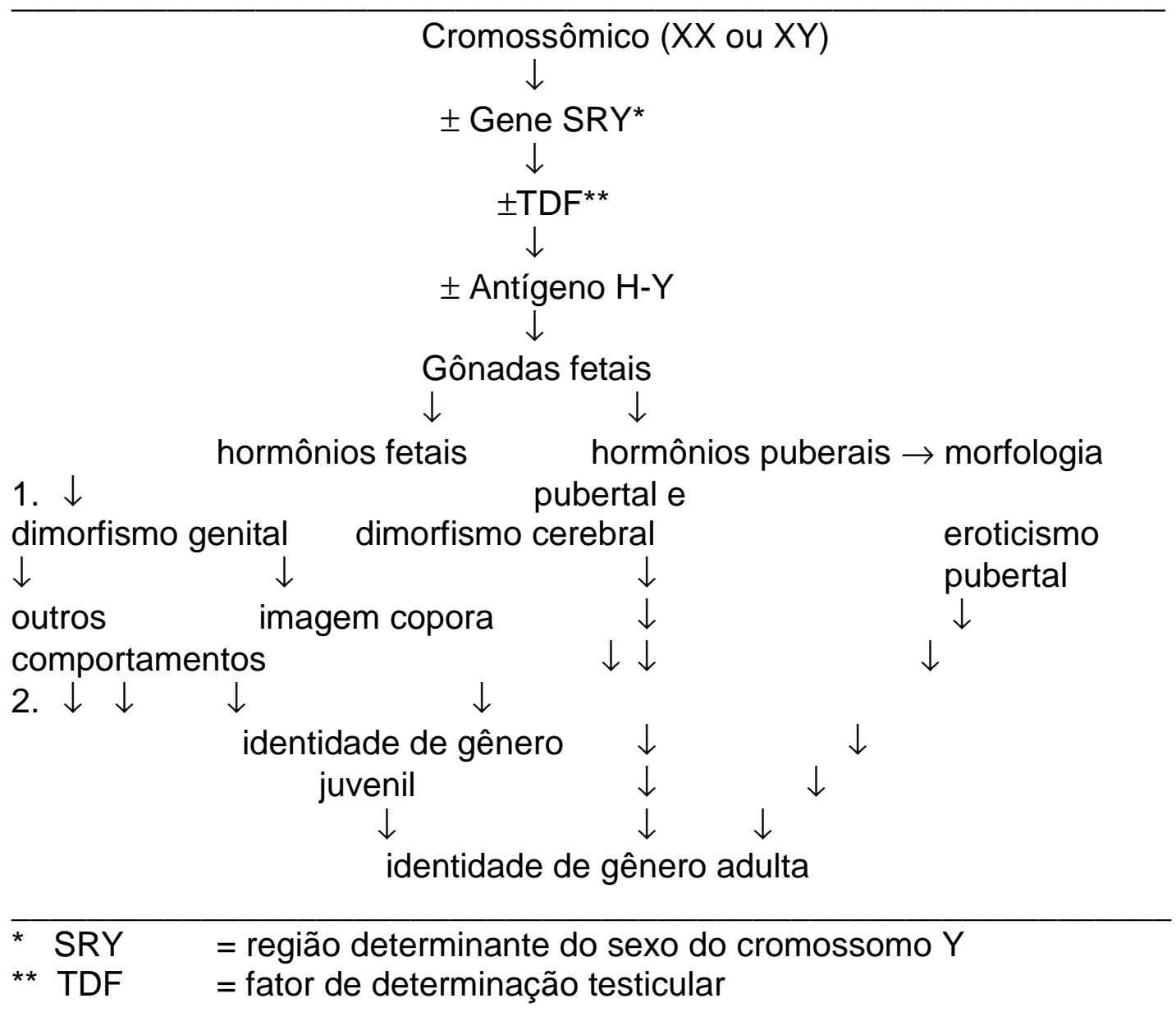

Além da seqüência de diferenciação de gênero, os autores definem dois conceitos importantes para o entendimento do transexualismo e do interssexo, que já eram conhecidos desde os anos 60. São eles:

Identidade de gênero: a identidade, harmonia e persistência da individualidade de alguém como masculina (homem), feminina (mulher) ou ambivalente, em maior ou menor grau, especialmente como ela é experimentada com sua própria consciência e comportamento; identidade de gênero é a 
experiência privada do papel de gênero e papel de gênero é a expressão pública da identidade de gênero.

Papel de gênero: tudo o que uma pessoa diz e faz para indicar aos outros ou a si mesmo seu grau de masculinidade, feminilidade ou ambivalência; isso inclui, mas não se restringe, ao desejo e resposta sexual; papel de gênero é a expressão pública da identidade de gênero e identidade de gênero é a experiência privada do papel de gênero (MONEY, EHRHARDT, 1996, p. 4).

Robert Stoller, psicanalista importante no estudo do transexualismo, na década de 60 separa sexo de gênero, atribuindo a sexo uma definição biológica e a gênero, uma definição sócio-psicológica (PERSON, 1999).

Essa separação entre o biológico e o psicológico torna-se realidade com a visão do sexo como quatro formas físico-psicológicas distintas, mas relacionadas, tanto na visão de Money quanto na de Stoller (PERSON, 1999):

1. sexo biológico definido por seis características anatômicas e fisiológicas: cromossomos, gônadas, genitália interna, genitália externa, hormônios e caracteres sexuais secundários;

2. gênero, composto pela identidade de gênero, ou núcleo da identidade de gênero (noção de ser "macho" ou "fêmea", homem ou mulher) e pelo papel de gênero ou papel de identidade de gênero (noção de ser masculino ou feminino) e comportamento ligado ao papel de gênero; 
3. comportamento sexual, declarado e fantasiado, expresso em ambos pela escolha do objeto e natureza da atividade;

4. reprodução, capacidade biológica relacionada com a propagação da espécie.

No início dos anos 70, o transexualismo foi aceito oficialmente como síndrome e foram desenvolvidas extensas pesquisas, publicações e programas de tratamento. Em 1973, o termo disforia de gênero foi criado, incluindo genericamente aqueles indivíduos que sofrem de algum tipo de desconforto de gênero (LAUB, 1973; LAUB, FISK, 1974; PAULY, 1998).

Em 1977, sexologistas ligados à questão de gênero formaram a Harry Benjamin International Gender Dysphoria Association e desenvolveram código e estatuto de tratamento padrão (IRVINE, 1990).

Finalmente, o termo "transtorno de identidade de gênero" tem sido usado para descrever os indivíduos com disforia de gênero desde 1980, com a publicação do DSM-III (“Diagnostic and Statistical Manual”, 3rd edition) pela American Psychiatric Association. O uso do termo transexualismo e transtorno de identidade de gênero, presente no DSM-III e na revisão de 1987 (DSM-III-R), legitimou um lugar para esses transtornos no universo psiquiátrico e médico. Para o DSM-IV, em 1994, um grupo liderado por Susan Bradley melhorou os critérios e a descrição desses transtornos, retirando os termos disforia de gênero, transexualismo e transgênero (APA, 1980; APA, 1987; APA, 1994; PAULY, 1998). Este mesmo direcionamento se mantém no DSM-IV-TR (APA, 2000). 
A Classificação Internacional de Doenças, 10av versão (CID-10), da Organização Mundial de Saúde (OMS), Capítulo V, Transtornos Mentais e do Comportamento, inclui nos chamados Transtornos de Identidade Sexual o transexualismo, o transvestismo de duplo papel e os transtornos de identidade sexual na infância, além dos genéricos, outros transtornos de identidade sexual e transtorno de identidade sexual não especificados (OMS, 1993).

\subsection{A questão transexual no Brasil}

Meu pai me disse, meu filho, tá muito cedo eu tenho medo que você case tão moço

eu me casei e veja o resultado

eu tô atolado até o pescoço

Minha mulher apesar de ter saúde foi prá Hollywood, fez uma operação agora veio com uma nova bossa uma voz grossa que nem um trovão quando eu pergunto o que é isso, Joana?

Ela responde: você se engana eu era Joana antes da operação mas de hoje em diante meu nome é João não se confunda nem troque meu nome fale comigo de homem prá homem fique sabendo mais de uma vez que você me paga tudo que me fez agora eu ando todo encabulado e essa mágoa é que me consome por onde eu passo todo mundo diz aquele é o marido da mulher que virou homem.

(ELIAS SOARES, JACKSON DO PANDEIRO - A Mulher que Virou Homem)

No Brasil, é uma constante histórica o entendimento de que todo comportamento sexual entre pessoas do mesmo sexo biológico seja 
expressão de homossexualidade. Mesmo o transvestismo, com ou sem atividade sexual, encontra-se incluido nessa maneira de entender tais comportamentos (TREVISAN, 1986; GREEN, 2000).

Além de ter, desde o descobrimento, o estigma de paraíso sexual, o Brasil carrega ainda como aspecto cultural o fato de ser comum no carnaval o fenômeno de transvestismo, o que gera a impressão de que a homossexualidade, o transvestismo e o transexualismo são aceitos e disseminados no país (GREEN, 2000).

Segundo GREEN (2000, p. 23):

Para muitos observadores estrangeiros, de Buenos Aires a São Francisco e Paris, essas imagens variadas dos homossexuais brasileiros, extrovertidos e licenciosos, que expressam a sensualidade, a sexualidade ou a atitude camp durante o carnaval, acabaram sendo confundidas com uma suposta tolerância da homossexualidade e da bissexualidade nesse país. A permissividade aberta do carnaval, assim diz o esteriótipo, simboliza um regime sexual e social que aceita a ambigüidade sexual sem restrições, incluindo a sexualidade do homem em relação ao homem.

Contribui para isso a realidade de que no país não existem leis antihomossexuais na Constituição nem Código Penal. Esse fato, contudo, não impede a ocorrência de repressão policial e atitudes discriminatórias no diaa-dia (TREVISAN, 1986). Além do quê, pela herança cultural católica e latina, é considerado homossexual o homem que apresenta trejeitos 
femininos, ou seja, é afeminado. Portanto, a dificuldade em se definir transexualismo como outra variável de comportamento humano ainda é difícil e a confusão com travestis permanece (GREEN, 2000). O autor exemplifica essa confusão permanente ao relatar o caso de um homossexual:

Nascidos com genitais masculinos mas sexualmente atraídos por outros homens, alguns pensavam que sua essência, alma, espírito, ou pensamento eram, na verdade, femininos, e estavam encarcerados erroneamente num corpo masculino. Nem sua provável formação católica, ou meio social em que foi criado no Brasil rural, nem o aconselhamento médico ofereceram a Marina um modelo alternativo para construir sua identidade sexual e social. Seu desejo de servir, de assumir o papel tradicional da mulher num relacionamento, parecia-lhe a única opção disponível (GREEN, 2000, p. 136-137).

Para COSTA (1992), mesmo o conceito de homossexualidade estaria ultrapassado. Com isso, propõe o termo homoerotismo que desconstrói o sentido médico científico e introduz uma noção de desejo sexual pelo mesmo sexo. Já o conceito de identidade sexual não fica claro se pertenceria a esta categoria ou não, apesar do conteúdo contestador presente no desejo e na crença verdadeira de pertencer ao sexo oposto.

Todas essas referências, apesar de pouco esclarecedoras, são pertinentes à homossexualidade e ao transexualismo masculino. A 
homossexualidade, o transvestismo e 0 transexualismo feminino permanecem em terreno obscuro no Brasil.

Já no campo da cirurgia de redesignação sexual, muito se evoluiu nesses últimos 30 anos. Segundo COUTO (1999), a primeira cirurgia, que prefere chamar de adequação sexual, realizada no Brasil foi em 1971 pelo Dr. Roberto Farina. O custo desse pioneirismo foram dois processos, um criminal e outro no Conselho Federal de Medicina. O médico foi considerado culpado nos dois processos.

Contudo, de acordo com COUTO (1999), desde a década de 70 muitos transexuais brasileiros realizaram as cirurgias de redesignação sexual ilegalmente, no Brasil ou fora (Europa: Dinamarca e Inglaterra; África: Marrocos; América do Sul: Equador).

Paralelamente a esses acontecimentos, no campo jurídico e legal têm início algumas atitudes isoladas. Em 1979 foi apresentado projeto de lei de autoria do deputado José de Castro Coimbra que regulamentava na esfera jurídica a problemática das pessoas transexuais. Apesar de aprovado pelo Congresso Nacional, foi vetado pelo Presidente da República João Figueiredo (INACIO, 1998; COUTO, 1999).

Atualmente tramita no Congresso Nacional outro projeto de lei de autoria do deputado federal José Fortunato que regulariza as questões vitais dos transexuais, como cirurgia e alteração de nome e documentos (COUTO, 1999).

Com a aprovação da Resolução 1482/97 do Conselho Federal de Medicina (CFM) autorizando, segundo determinados critérios, a realização 
da cirurgia de transgenitalização, o panorama mudou. "Acredita-se que existam cerca de 1.500 transexuais operados no Brasil e que pelo menos mais 1.200 estejam na fila aguardando a autorização para a cirurgia" (COUTO, 1999, p. 38).

Essa Resolução (CFM, 1997) resolvia:

1. autorizar, a título experimental, a realização de cirurgia de transgenitalização do tipo neocolpovulvoplastia, neofaloplastia e ou procedimentos complementares sobre gônadas e caracteres sexuais secundários como tratamento dos casos de transexuailismo;

2. a definição de transexualismo obedecerá, no mínimo, aos seguintes critérios: desconforto com o sexo anatômico natural; desejo expresso de eliminar os genitais, perder as características primárias e secundárias do próprio sexo e ganhar as do sexo oposto; permanência desse distúrbio de forma contínua e consistente por pelo menos dois anos; ausência de outros transtornos mentais;

3. a seleção dos pacientes para cirurgia de transgenitalismo obedecerá à avaliação de equipe multidisciplinar constituída por médico-psiquiatra, cirurgião, psicólogo e assistente social, segundo os critérios definidos, após dois anos de acompanhamento conjunto: diagnóstico médico de transexualismo; maior de 21 anos; ausência de características inapropriadas para cirurgia; 
4. as cirurgias só poderão ser praticadas em hospitais universitários ou hospitais públicos adequados à pesquisa;

5. consentimento livre e esclarecido, de acordo com a Resolução CNS nำ 196/96.

Em 2002, o Conselho Federal de Medicina aprova nova Resolução, a de número 1652/2002, que amplia o já disposto na Resolução 1482/97 (CFM, 2002):

1. autoriza a cirurgia de transgenitalização do tipo neocolpovulvoplastia e/ou procedimentos complementares sobre gônadas e caracteres sexuais secundários como tratamento dos casos de transexualismo;

2. autoriza, ainda a título experimental, a realização de cirurgia do tipo neofaloplastia e/ou procedimentos complementares sobre gônadas e caracteres sexuais secundários como tratamento dos casos de transexualismo;

3. mantém as definições de transexualismo;

4. mantém a seleção dos pacientes;

5. as cirurgias para adequação do fenótipo feminino para masculino só poderão ser praticadas em hospitais universitários ou hospitais públicos adequados para a pesquisa;

6. as cirurgias para adequação do fenótipo masculino para feminino poderão ser praticadas em hospitais públicos ou privados, independente da atividade de pesquisa. 
Com isso, o tratamento dos transexuais masculinos se ampliou e o dos transexuais femininos continua em pesquisa.

A partir da Resolução de 1997 os transexuais vêm tendo maior visibilidade e suas questões, maior transparência social, seja em matérias de revistas, jornais, televisão, novela e até em política. No início, por conta das primeiras cirurgias realizadas; depois, por questões de cidadania.

Bianca Magro, registrada como Edilson, foi a primeira transexual a ser operada gratuitamente, no Hospital das Clínicas da Universidade Estadual de Campinas (UNICAMP), em 8 de abril de 1998, depois que a cirurgia foi autorizada pelo CFM (COUTO, 1999).

Em São José do Rio Preto, no Hospital de Base e na Faculdade de Medicina, desde dezembro de 1998 são realizadas cirurgias de redesignação sexual.

Foi noticiado no jornal Folha de São Paulo de 22 de dezembro de 2002 sobre Camille Cabral, transexual brasileira, médica e conselheira municipal em Paris, cidade onde exerce sua cidadania. Foi na França que Camille se revelou transexual e se casou por duas vezes. Hoje, viúva de seu segundo marido, trabalha com questões relativas a doenças sexualmente transmissíveis e minorias como conselheira municipal eleita pelo $16^{\circ}$ "arrondissement" de Paris pelo Partido Verde.

No Hospital das Clínicas da Faculdade de Medicina da Universidade de São Paulo, mais especificamente na Unidade de Endocrinologia de Gônadas e Intersexo da Primeira Clínica Médica, existe um trabalho médico e psicológico com transexuais desde meados dos anos 70. Com o advento 
da resolução do CFM juntou-se à equipe um urologista e, posteriormente, cirurgiões plásticos no atendimento aos transexuais (INACIO, 1998).

No Instituto de Psiquiatria do Hospital das Clínicas da Faculdade de Medicina da Universidade de São Paulo (Ipq HCFMUSP), nos anos 80, 0 psiquiatra Renato Del'Sant iniciou trabalho pioneiro e específico de estudo e atendimento dessa população, mas que pela impossibilidade cirúrgica na época, não teve continuidade.

Com a inauguração do ProSex em 1993, muitos transexuais buscaram esse serviço interessados em acompanhamento e cirurgia.

Mas foi com a resolução do CFM de 1997 que um trabalho efetivo, que conta com adesão dos pacientes, vem funcionando.

Em conjunto com a Endocrinologia, o ProSex integra uma equipe multidisciplinar e coesa, desde 1999, discutindo critérios diagnósticos, questões éticas, manejo terapêutico, psicoterapia e questões práticas do diaa-dia como, por exemplo, dificuldades em se marcar cirurgia etc.

Em 2001, cria-se o Protig - Programa de Transtorno de Identidade de Gênero (DSM-IV) / Transexualismo (CID-10) - no Hospital das Clínicas de Porto Alegre em associação com a Universidade Federal do Rio Grande do Sul (LOBATO et al., 2001).

Nos dias atuais, em que a realização das cirurgias de redesignação sexual parece algo irrevogável, o grande problema se situa na condição legal e jurídica da pessoa operada. Apesar de não existir decisão formal, muitos pacientes têm conseguido, ainda que de forma isolada, a mudança de nome e sexo no registro civil, o que leva à alteração de toda a 
documentação e a uma diminuição do constrangimento cotidiano a que eram expostos (ARAUJO, 2000).

\subsection{Etiologia}

\subsubsection{Perspectivas biológicas}

Embora décadas de especulações tenham ocorrido, sugerindo uma base biológica ou genética para o transexualismo, pouca evidência que dê suporte a essas teorias foi encontrada (GREEN, 2000).

Desde pesquisas recentes, envolvendo comportamento animal e evolução, até as que relacionam genética e dimorfismo cerebral, tudo ainda se baseia em hipóteses.

GEWIN (2003), analisando o livro Evolutions Rainbow de Joan Roughgarden (antigamente conhecida como John Roughgarden pesquisador transexual que mudou de sexo aos 52 anos), encontra dados que se mostram contrários à visão de Darwin a respeito da seleção sexual. Nesse livro é catalogada a enorme variedade de gêneros e comportamentos sexuais presente no reino animal e não apenas a descrição de machos ardentes procurando favores de fêmeas que podem ou não escolhê-los.

Deixando de lado a seleção sexual e buscando evidências de fatores biológicos como determinantes na gênese dos transtornos de identidade de gênero, historicamente têm-se duas linhas de pesquisa: a que envolve fatores hormonais, que vem se desenvolvendo desde a década de 
70 e evoluiu desde a busca por alterações quantitativas de hormônios até a influência dos hormônios masculinos na diferenciação cerebral; e a que busca alterações genéticas e/ou cromossômicas. Serão vistos a seguir alguns resultados já alcançados com essas pesquisas.

Nos anos 70, DÖNER (1996) realizou experimentos com animais com base no fato de que a diferenciação sexual perinatal das áreas neuroendócrinas do sistema nervoso central é regulada pelo hormônio luteinizante $(\mathrm{LH})$. Utilizando este hormônio como marcador biológico, ele observou que ratos machos tinham o comportamento sexual revertido na vigência de um déficit androgênico induzido. A extrapolação desse modelo para o ser humano não se comprovou.

Uma teoria envolvendo a falta do antígeno HY como etiologia foi proposta quando uma série de transexuais masculinos foi identificada como não tendo este antígeno, responsável pela diferenciação masculina (EICHER et al., 1979). Esforço em identificar esse mesmo achado em outras séries de transexuais masculinos falhou, pois todos tinham o antígeno HY (WACHTEL et al., 1986).

Um achado endocrinológico que precisa ser confirmado é uma forma atípica de hiperplasia adrenal em transexuais femininas (DÖRNER, 1991; BOSINSKI et al., 1997).

Outros trabalhos indicaram alto e inesperado índice de doença dos ovários policísticos em transexuais femininos (FUTTERWEIT et al., 1986). Todavia, a ligação entre esses dois transtornos não se estabeleceu, pois a grande maioria de mulheres com este transtorno não é transexual e a 
grande maioria dos transexuais femininos não apresenta este transtorno (GORZYNSKI, KATZ, 1977; RABOCH et al., 1985).

FORGET e COHEN (1994), analisando a influência do hormônio testosterona na função e estrutura cerebral, observam que transexuais geneticamente masculinos e homens apresentam diferentes padrões de lateralização auditiva - ou que transexuais geneticamente masculinos e mulheres exibem padrões similares de lateralização auditiva acrescentando evidências à hipótese de que a influência neuroendócrina na modulação da assimetria funcional cerebral não é necessariamente determinada no cérebro perinatal.

Essa correlação entre hormônio masculino e a diferenciação e desenvolvimento cerebral e comportamento masculino e feminino, passa a ser uma linha de pesquisa fundamental nos últimos anos.

Estudos anatômicos correlacionando tamanho de determinadas regiões do hipotálamo ("bed nucleus da stria terminalis") entre transexuais masculinos e mulheres obteve alguma evidência, apesar do estudo ter sido feito com apenas 6 indivíduos "postmortem", em 11 anos de pesquisa (ZHOU et al., 1995). Esses achados não se mostraram diferenciados quanto à idade de manifestação do transexualismo, ou seja, a diminuição do núcleo guarda relação com o transtorno de identidade e não com a idade do paciente na manifestação do transtorno. Outro achado é que o tamanho do núcleo não mostra diferença entre homens hetero e homossexuais (ZHOU et al., 1995). 
Estudo mais recente (KRUIJIVER et al., 2000), utilizando 42 cérebros de pacientes - sendo que 26 eram do mesmo estudo de ZHOU et al. (1995), chegou à conclusão de que o número de neurônios no "bed nucleus da stria terminalis" de transexuais masculinos é similar ao das mulheres e , em contraste, o número de neurônios de uma transexual feminina (apenas o cérebro de uma transexual feminina foi analisado) é eqüivalente ao de um homem. Os autores concluem que, em transexuais, a diferenciação do cérebro e dos genitais corre em direções opostas e indica a base neurobiológica do transtorno de identidade de gênero.

SWAAB et al. (2002) referem que a diferenciação do hipotálamo ocorre aproximadamente por volta dos quatro anos de idade e depende de fatores genéticos e níveis de hormônios pré-natais. A mesma relação entre comportamento masculino e andrógenos é estabelecida por GOOREN e KRUIJIVER (2002).

GREEN (2000) revela que outros achados indiretos, ainda pouco conclusivos, têm sido propostos como marcadores biológicos: uso preferencial de mãos (refletindo lateralidade cerebral organizada antes do nascimento), com transexuais masculinos e femininos utilizando mais a mão esquerda do que os controles; padrões de assimetria em impressões digitais, que se desenvolvem antes do nascimento e provavelmente são influenciados por sexo-esteróides, tanto em transexuais masculinos quanto femininos, diferindo dos controles, homens e mulheres (GREEN, YOUNG, 2001); ordem de nascimento, com os transhomossexuais masculinos tendo irmãos mais velhos, dado similar ao encontrado com homossexuais 
masculinos não transexuais (GREEN, 2000) e, por fim, os transexuais masculinos tendo mais tias maternas do que tios maternos, achado similar aos dos homossexuais masculinos não transexuais (GREEN, KEVERNE, 2000).

RAHMAN e WILSON (2003) encontram em homossexuais evidências de que a influência de hormônios sexuais afeta a orientação sexual e o demonstram pela análise da relação de tamanho entre o segundo e o quarto dedo da mão. Homossexuais masculinos e femininos apresentaram uma menor relação entre o segundo e o quarto dedo em comparação com os heterossexuais. Isso, segundo os autores, evidencia ação de altas doses de andrógenos intra-útero. Apesar de relacionado à orientação sexual, essa influência genética pode ter relação com a formação da identidade de gênero em seres humanos.

As pesquisas genéticas e cromossômicas representam ainda um campo em desenvolvimento. Existem poucos relatos científicos descrevendo anormalidades cromossômicas em transexuais. TURAN et al. (2000) relatam o caso de uma mulher de 21 anos com depressão, que se descrevia como homem desde a infância e que possuia cariótipo de 47, XXX. HENGSTSCHLÄGER e TROTSENBURG (2003), em trabalho relacionando aberrações sexuais e transexualismo, afirmam ser sempre necessária a investigação dos cromossomos sexuais nessa população.

Mesmo a ocorrência de transexualismo entre irmãos, familiares e mesmo gêmeos (mono ou dizigóticos) é rara, mas há alguns relatos na literatura, embora sejam pouco conclusivos quanto a uma causa genética 
(ANCHERSEN, 1956; GREEN, STOLLER, 1971; HORE, et al., 1972; STOLLER, BAKER, 1972; HYDE, KENNA, 1977; BALL, 1981; GREEN, 2000)

Recentemente, DEWING et al. (2003), trabalhando com ratos 10,5 dias após o coito, sugerem que fatores genéticos devem ter influência na diferenciação sexual cerebral, pois conseguiram identificar genes que diretamente induzem padrões dimórficos de desenvolvimento neural e que podem influenciar as diferenças sexuais entre os cérebros masculinos e femininos antes da ação dos hormônios esteróides gonadais.

As pesquisas em busca de uma perspectiva biológica prosseguem, mas sem achados definitivos ou conclusivos sobre o assunto.

\subsubsection{Perspectivas psicológicas}

Serão abordados a seguir as visões psicanalítica e psicodramática do transexualismo em virtude da importância dos estudos psicanalíticos do tema e da formação teórica do autor que fundamentam o trabalho aqui proposto.

Antes de dar início à revisão ampla das perspectivas psicológicas das causas do transexualismo, vale a pena ressaltar que Freud não abordou o transexualismo como situação clínica estabelecida (GARCIA, 2001) pois, no final do século $X I X$ e início do século $X X$, tal termo e conceituação 
médica não eram evidentes, sendo a questão vista como variação do amplo tema do homossexualismo.

Em 1911, Freud publicou o "Caso Schreber" baseado na leitura do livro "Memória de um doente dos nervos" de Daniel Paul Schreber, publicado em 1903, que relatava em detalhes suas experiências psicóticas e, em especial, aspectos presentes em seus delírios, nos quais expressava desejos e sensações de se transformar em mulher (SCHREBER, 1984).

Este é um caso interessante que Freud analisou e sobre o qual desenvolveu e aprimorou suas teorias a respeito da dinâmica da psicose, especialmente a paranóia (GARCIA, 2001; FREUD, 1973).

No entanto, este não pode ser caracterizado como transexualismo, pois se enquadra em uma categoria diferencial importante, a dos psicóticos, que em suas manifestações delirantes podem se sentir pertencentes ao gênero oposto ao do seu nascimento.

A partir da década de 70 do século XX, estudiosos da psicanálise e de diversas escolas psicológicas procuraram sistematizar conhecimento a respeito do tema. As dificuldades conceituais e as divergências em relação aos referenciais psíquicos, apesar de aumentar a confusão já existente, contribuiram com informações e observações valiosas.

Segundo MICHEL et al. (2001) existem duas categorias psicológicas de entendimento da etiologia do transexualismo: uma hipótese não-conflitiva e outra, conflitiva.

A hipótese não-conflitiva avalia a relação mãe-filho como sendo emocional e corporalmente feliz e que se prolonga em uma simbiose na qual 
o menino se identifica com o gênero da mãe. Já a hipótese conflitiva é um mosaico de diferentes teorias propostas no qual o pedido de mudança sexual nada mais é do que uma "formação de compromisso patológico", ou seja, "nesse contexto o transexualismo é considerado uma defesa contra a homossexualidade, uma forma de perversão, um transtorno narcísico ou uma perturbação da fase de separação-individuação" (MICHEL et al., 2001; FERRAZ, 2002). Segundo os mesmos autores, haveria concordância geral de que o transexualismo apareceria como manifestação de um transtorno de personalidade do tipo "borderline", pois os transexuais apresentam muitas características similares à desses indivíduos (ansiedade crônica, difusa e flutuante; isolamento; depressão; baixa tolerância ao estresse; etc.).

STOLLER (1982, p. 74), importante estudioso do transexualismo e da psicanálise, foi um dos primeiros a distingüir sexo (manifestação biológica) de gênero (manifestação sócio-cultural):

As experiências não podem ser reproduzidas à vontade, mas apenas por uma mãe motivada a interagir em seu filho durante todo o dia e por anos, com toda a complexa intensidade que forma o comportamento maternal... nenhuma simples experiência behavorista em laboratório pode estimular as psicodinâmicas de vida que produzem um transexual.

Privilegiando essas experiências, Stoller desenvolve maneira particular de pensar e entender apenas o transexualismo masculino e que, segundo ele, teria como possível origem a següinte seqüência: 
1. invasão da mãe em seu filho e a proximidade entre eles: extrema simbiose entre mãe e filho, gerando identificação intensa que não é rompida.

Aparentemente não existe conflito edipiano na situação edipiana. Isto porque não existe (praticamente) pai. O menino não tem rival em relação à sua mãe; ele a possui, talvez mais completamente do que o possa qualquer outra criança, porque eles são praticamente um (STOLLER, 1982, p. 28).

O filho não se sente ameaçado em sua virilidade e masculinidade pelo pai, por isso o conflito edipiano não se estabelece.

2. ausência do pai: a figura paterna não ameaça e não estabelece um conflito edipiano. A escolha da mãe por um pai com as características de ausente, infantil, desleixado consigo e com o mundo ou mesmo alcoólatra e/ou distante não é por acaso e tem relação direta com a forma dessa mãe encarar a própria sexualidade e a relação com esse filho.

3. passividade e a bissexualidade do pai: Esses pais, não são apenas incapazes de tomar parte na família como homens masculinos, mas o seu relacionamento com as esposas é distante e mal-humorado. Eles não desejam assumir a responsabilidade de sua função de marido e pai, mas, sem reclamações, persistem em um casamento sem amor e quase 
sem sexo (STOLLER, 1982, p. 68-69). Alguns até demonstram efeminação e sua bissexualidade.

4. baixa freqüência de divórcios: a taxa de divórcio costuma ser praticamente zero, apesar dos casamentos infelizes, com ataques de raiva, insatisfação sexual, desprezo e silêncios prolongados; mulheres poderosas e iradas que não podem abandonar seus maridos passivos; maridos calados que dizem que as coisas estão bem e não ouvirão o desespero atrás da hostilidade de suas esposas. O casamento é seguro e essencial para ambos e a separação seria um desastre.

5. a influência da irmã: uma irmã também pode reforçar ou dar origem ao comportamento feminino do irmão. Se a mãe não é tão competitiva nem ultramasculinizada, muitas vezes uma irmã pode sê-lo e, com isso, originar o comportamento no irmão.

Minha tese, a ser melhor testada no futuro, é de que o grau de feminilidade que se desenvolve em um menino irá variar exatamente (não aproximadamente) com aquilo que the tenha sido feito no início da infância (STOLLER, 1982, p. 71).

O mesmo autor faz ainda duas ressalvas importantes no tocante ao transexual masculino: o transexual não é psicótico; ele sabe e reconhece que seu corpo é biologicamente masculino e que possui pênis e testículos. A segunda ressalva diz respeito ao conceito de bissexualidade que ele emprega. 
Por bissexualidade, queremos dizer a presença de qualidades masculinas e femininas demonstradas, na mesma pessoa. "Masculino" e "feminino", então, serão usados para demonstrar qualidades psicológicas e não biológicas (STOLLER, 1982, p. 40).

STOLLER (1982) refere ainda que os transexuais masculinos teriam determinadas qualidades (ou características) de "personalidade psicopática" que seriam: leve irresponsabilidade, não de uma maneira hedonística criminosa, mas em seus compromissos, especialmente com o terapeuta; mentira infantil, que não traz nenhum benefício óbvio para o paciente e sobre detalhes pouco importantes; não têm relacionamentos duradouros com outras pessoas, as relações que estabelecem são aparentes e pouco profundas. Por fim, não têm comportamento criminoso.

A explicação que STOLLER (1982) oferece para essas características é a "falta de uma firme relação transferencial", pois se não há conflito edipiano, não há potencial de um vínculo intenso. Portanto, não há possibilidade de uma relação transferencial, daí a dificuldade em se psicanalisar um transexual. E vai mais longe, relatando a dificuldade de se estabelecer empatia e contra-transferência com essa população.

STOLLER (1982) diz ainda, sem revelar detalhes, que o transexualismo masculino e o feminino têm dinâmicas diferentes.

CHILAND (2000), psicanalista francesa, opõe-se a algumas das idéias de Stoller. Discorda quando ele diz que os pais não comparecem ao tratamento, apenas a uma ou outra entrevista. Em sua experiência com 
crianças (transtorno de identidade sexual na infância - gender identity disorder (GID) children) ela encontrou participação dos pais no processo psicanalítico dos filhos. Outro ponto de discórdia seria a "simbiose extasiante" e totalmente sem conflito entre mãe e filho. A autora afirma ter encontrado uma situação na qual a mãe viveria essa "simbiose extasiante", mas a criança experimentaria duas vivências: uma de felicidade fantástica e outra de perigo de destruição.

CHILAND (2000) descreve que crianças com transtorno de identidade sexual interpretam as mensagens conscientes e inconscientes de seus pais como não sendo amadas por serem quem são, especialmente em relação ao gênero ao qual pertencem, portanto não podem amar a si próprias se não pertencerem ao sexo oposto. Embora os pais possuam um papel importante, essa causalidade não é linear, os pais são muitas vezes experenciados como ausentes ou pouco presentes, mas isso não corresponde necessariamente à realidade.

Outras características analisadas pela autora são a resistência dos transexuais em falar - falam pouco ou não falam - sobre sua infância; sua resistência à transferência, já que, fechados em suas "conchas narcísicas", não se importam com as reações próprias do analista ao que falam; e por fim, questiona-se sobre o quê vem antes, se a identificação com o sexo oposto ou a rejeição de seu próprio sexo.

Quanto ao transexualismo feminino, a autora diz:

As transexuais femininas não têm, como regra, experiências felizes com suas mães na tenra infância. Elas foram incapazes 
de valorizar as mamas como a base da experiência da amamentação. Elas freqüentemente tiveram mães deprimidas, que sofreram por ser mulher e depois retiraram a feminilidade de seus valores. Elas às vezes estabeleceram experiências positivas com seus pais, não em nível edípico, mas como companheiras de atividades realizadas com sucesso e reconhecidamente de homens em nossa cultura. Na realidade, seus pais freqüentemente foram pouco participativos e incapazes de conferir valor às suas esposas, de protegê-las e tirá-las da depressão. Essas pacientes se obrigam a reparar e ajudar suas mães e adotam um papel masculino de proteção em relação às suas companheiras femininas (CHILAND, 2000).

Outra autora, a psicanalista parisiense Agnès Oppenheimer, posiciona-se a favor das idéias de Stoller e acrescenta-lhes alguns dados (OPPENHEIMER, 1991):

- transexuais são invadidos por uma obsessão, uma crença invasiva sobre sua transformação corporal;

- $\quad$ eles não apresentam nem transvestismo perverso nem psicose;

- $\quad$ eles são desconfiados, mentem facilmente, vêem as diferenças entre os sexos de forma estereotipada, trivializam seus problemas, e como não se reconhecem homossexuais, desaprovam completamente a homossexualidade. 
OPPENHEIMER (1991), ao analisar a possível origem do transexualismo masculino, diz que existiria uma grave depreciação da masculinidade e um intolerável sentimento de castração associado a um ferimento narcísico no indivíduo. Associado a isso, as funções parentais estão aparentemente desconectadas com as diferenças entre os sexos, o que não faz nenhum sentido para o filho. Não há identificação com o pai, que é desvalorizado e perigoso, enquanto a identificação com a mãe seria uma compensação acompanhada de idealização. A relação com essa mãe é complicada pois ela faz do filho um espelho para si mesma e não inclui uma masculinidade, mesmo que infantil. $\mathrm{O}$ pai não intervém para quebrar esse sistema e, além de não admirar o filho, não permitirá que esse o idealize. 0 filho percebe esse ódio e se volta para a mãe para satisfazer suas necessidades de idealização. Além de identificar-se com ela, estabelece um vínculo reparatório para satisfazê-la de suas frustrações. Com isso seu narcisismo está estabelecido, bem como sua identificação com a mãe e sua necessidade de gratificá-la.

Vários autores psicanalíticos (CARDER, 1992; CHILAND, 1998; QUINODOZ, 1998) discutem também outros temas fundamentais da questão transexual: a identificação, o não reconhecimento-corporal, capacidade ou incapacidade de estabelecer transferência, narcisismo, referenciados nos estudos de Stoller e Oppenheimer.

OVESEY e PERSON (1973), psicanalistas que ainda hoje servem de referência ao estudo do transexualismo, estabelecem que, mais que uma identidade de gênero feminina, os transexuais masculinos possuem uma 
identidade de gênero ambígüa. Desde pequenos eles têm um desejo, não uma conviç̧ão. "Eu gostaria de ser uma menina" e não "Eu sou uma menina". A convicção cristalizada só acontece quando o paciente aprende sobre a existência do transexualismo. A maioria dos pacientes comumentemente fala de suas dúvidas e da confusão sobre o quê e quem são - heterossexual, homossexual, travesti - até aprenderem e lerem sobre transexualismo. Na opinião dos autores, o transexualismo se origina na intensa ansiedade de separação que ocorre cedo na vida, antes que a diferenciação objetal tenha se completado. Para aliviar a ansiedade, a criança recorre a uma fantasia de fusão simbiótica com a mãe. Dessa forma, mãe e criança tornam-se um só e o perigo de separação é anulado.

Os autores acreditam que esta fantasia reparativa é a base psicodinâmica do transexualismo masculino e que o fenômeno do transexualismo pode ser entendido clinicamente como uma tentativa de defesa contra a ameaça de fusão com a mãe. Esta fantasia é tão poderosa que esvazia a vida sexual desses pacientes. É notória a assexualidade dos transexuais "verdadeiros". Muitos resumem sua vida sexual antes da cirurgia a uma masturbação quase que sem fantasias, mecânica, em que surgem vagas expressões fantasiosas heterossexuais nas quais o paciente vê a si mesmo como mulher. O prazer nesses casos é mínimo, beirando uma anedonia.

PERSON e OVESEY (1974) evoluem sua conceituação estabelecendo os conceitos de transexualismo primário e secundário. No transexualismo primário, a criança recorreria a uma fantasia reparativa de 
fusão simbiótica com a mãe para conter a ansiedade de separação. Esta seria a etapa mais primitiva de um "continuum" de desenvolvimento e geraria uma identidade de gênero ambígua que impediria um desenvolvimento sexual adequado, levando os indivíduos a uma relativa assexualidade e a uma atividade masturbatória pouco prazerosa e fantasiosa.

Já em relação ao transexualismo secundário, dividido em transexualismo homossexual e transexualismo transvéstico, não ocorre a fusão simbiótica com a mãe mas, sim, uma relação transicional com objetos parciais. Neles a vida sexual pode ser intensa. Dessa maneira, pode-se pensar em uma "síndrome transexual", evoluindo desde um transexualismo primário a um secundário. Com isso, estabelece-se uma abordagem e conduta para os transexuais, além de uma visão na qual o tratamento pode ser diferenciado baseado na evolução psicodinâmica, adequação social, adequação pessoal e vida sexual.

COSTA (1992, p.146), psicanalista brasileiro, analisa o que denomina comportamento homoerótico:

O importante para a psicanálise não é dizer que o homem é "por natureza" bom ou mau. O homem, disse Hannah Arendt, só existe no plural. Não existe uma "natureza humana"; existem condições humanas.

Já a respeito do desenvolvimento do transexualismo feminino, poucos autores ligados à psicanálise desenvolvem hipóteses. Encontra-se em SOCARIDES (1970) a descrição de quatro características presentes em 
"transexuais femininos verdadeiros" que também podem ser aplicadas aos transexuais masculinos:

1. intenso, insistente e persistente desejo de ter seu corpo transformado no de uma pessoa do sexo oposto;

2. convicção de ter sido aprisionado no corpo do sexo errado;

3. imitação concomitante do comportamento de uma pessoa do sexo oposto;

4. uma procura insistente de transformação sexual por meio de cirurgia e de uso de hormônios.

Os psicanalistas VOLKAN e MASRI (1989), seguindo as diretrizes de Socarides, apresentam características de desenvolvimento psicológico ligadas ao transexualismo feminino. São elas:

1. está associada à fase pré-edípica, entre os 18 meses e três anos de idade;

2. sua identidade masculina se inicia precocemente na vida e se manifesta pelo uso de objetos entre as pernas, simulando um pênis;

3. o desenvolvimento da identidade masculina está ligada à relação estabelecida com a mãe e à ausência do pai. A mãe é usualmente deprimida e sexualmente faminta. A menina, para compensar o sofrimento materno, de forma inconsciente, se identifica como homem e passa a usar objetos entre as pernas que substituem o pênis que lhe falta e a diferenciam da mãe deprimida e sofredora; 
4. na fase edípica, ao não contar com o reconhecimento paterno, identifica-se com ele para escapar da relação intensa com a mãe;

5. como conseqüência, a menina desenvolve a característica de ser centrada em si mesma e, na adolescência, o desejo cirúrgico de transformação para concretamente ter um pênis.

Em síntese, essas afirmações mantêm o eixo de raciocínio psicanalítico desenvolvido no entendimento do transexualismo masculino. A especificidade no tocante ao transexualismo feminino encontra-se na ligação com a mãe e na busca do pênis como aliviador do sofrimento materno e autenticador de sua identidade.

Por outro lado, a teoria do Psicodrama, menos difundida que a psicanalítica, apresenta algumas possibilidades sobre as psicodinâmicas da questão transexual, avaliando e realçando o contexto da relação entre mãe e criança, diferenciando-se assim da leitura intrapsíquica proposta pela psicanálise.

Jacob Levy Moreno, criador do Psicodrama e de sua teoria, aborda pouco a temática sexual, talvez como que para estabelecer sua oposição à Psicanálise. Em relação à sexualidade, há um texto no qual fala da necessidade de aquecimento para o ato sexual, visando uma melhor expressão deste (MORENO, 1978; MORENO,1993).

Já quanto à questão da identidade e sua construção, da qual podese ampliar para a identidade sexual, ele diz: 
Identidade não deve ser confundida com identificação. Identificação supõe a existência de um eu estruturado que tenta encontrar sua identidade com um outro eu igualmente estruturado. Identificação pode produzir-se apenas depois que a criança cresceu e desenvolveu sua capacidade de se distingüir de outras pessoas. Referimos, pois, identidade à fase mais precoce do desenvolvimento da criança (MORENO, 1974, p. 116).

Percebe-se que Moreno não se afasta muito da Psicanálise no entendimento da identidade como atividade primária e necessária para que ocorra uma identificação. Portanto, se há um problema de identidade sexual, haverá dificuldade na identificação sexual.

COSTA (1994) encara o transexualismo como uma inadequação extrema da identidade de gênero, resultando em grande sofrimento e "aprisionamento da alma feminina num corpo masculino" no caso de transexualismo masculino, ou o contrário, no caso de transexualismo feminino.

MERENGUÉ (1999) se reporta a Moreno na tentativa de compreender as sexualidades atuais, utilizando-se do conceito de espontaneidade criadora. O surgimento das novas sexualidades seria expressão de movimentos espontâneos e criativos. Portanto, o transexualismo pode ser entendido como manifestação criativa do ser humano, uma nova possibilidade de expressão sexual. 
Já FONSECA (2000) faz uma releitura da sexualidade como desenvolvimento e instrumento relacional, levando em conta a Teoria da Matriz de Identidade.

Essa é uma questão recorrente dos autores psicodramatistas; muitos deles, no que concerne o desenvolvimento humano, partem igualmente da relação mãe - bebê como primórdio decisivo na construção do psiquismo, assim como MORENO (1993), que declara: " a dedicação corporal do bebê à mãe é precursora do comportamento ulterior no papel sexual".

É a partir desse enunciado que se estrutura um dos referenciais teóricos do psicodrama, a Matriz de Identidade.

Por essa teoria, antes mesmo do bebê nascer, seu lugar no mundo já começa a ser planejado por aqueles que vão participar ativamente de seu processo de desenvolvimento e formação. Este planejamento inclui desde o espaço físico que o abrigará nesta chegada, os objetos que o circundarão, o clima afetivo desta espera e as expectativas daqueles que o aguardam, depositadas em um processo nem sempre consciente. A interação dos fatores materiais, sociais e psicológicos que ocorrem neste lugar préexistente, modificado pelo nascimento do sujeito, é o que se chama Matriz de Identidade (MORENO, 1993).

Para Moreno (1993), existiriam dois momentos específicos de desenvolvimento relacional entre um bebê e sua mãe. A esses momentos Moreno deu o nome de "universos". O primeiro, chamado de "universo da criança", compreenderia dois períodos: 
1ำ período: como o desenvolvimento psicológico ocorre paralelamente ao amadurecimento dos sistemas perceptivos, as noções de proximidade e distância físicas, percepção auditiva e visual apresentam-se como experiências múltiplas e indivisíveis, caracterizando-se por uma identidade total.

20 período: inicia-se uma diferenciação parcial que é também chamada de identidade total diferenciada, em que objetos, animais e pessoas começam a se tornar específicos. Tal diferenciação ainda não ocorre entre o real e o imaginário, entre a aparência das coisas e como elas realmente são.

No início do segundo universo formam-se dois conjuntos de processos de aquecimento preparatório. Um deles diz respeito aos atos de realidade e o outro, aos de fantasia. No indivíduo, os dois processos começam a se organizar simultaneamente, capacitando-o a passar de um ao outro e instrumentando a criança a lidar com suas fantasias e a realidade que a cerca.

Para MORENO (1993), o treino de espontaneidade como princípio consciente e construtivo opera este processo de aquecimento preparatório para o surgimento de dois novos conjuntos de papéis - os papéis sociais e psicodramáticos -, sendo a base psicológica para todos os processos de desempenho de papéis e para fenômenos, como a imitação. Estes processos estão nas fases da Matriz de Identidade que Moreno dividiu inicialmente em cinco: 
1a fase: a criança, a mãe e os objetos são uma coisa só. É chamada também de fase da indiferenciação.

2 fase: a criança concentra-se no outro e estranha parte dela.

3a fase: a atenção se inverte, a criança concentra-se nela mesma e o outro é parcialmente ignorado.

4ª fase: marca a presença dela e do outro. É capaz de tomar o papel do outro de forma a representá-lo.

5ª fase: a criança não só representa a outra parte como permite que o outro a represente (inversão de papéis ).

MORENO (1993) posteriormente agrupou essas cinco fases em três, para realçar suas características relacionais, e as denominou como:

Fase do Duplo: é a fase que corresponde à indiferenciação da criança em relação aos outros, a ela e a tudo que a cerca. Ela precisa de alguém que decodifique adequadamente suas necessidades físicas e psicológicas e que faça por ela o que ela não consegue fazer por si mesma; um outro eu ao qual Moreno deu o nome de ego-auxiliar.

Fase do Espelho: começa o processo de diferenciação entre a criança e o outro. O centro de sua atenção é flutuante, ora nela mesma, ora no outro. Nesta fase não consegue ainda estabelecer a diferença entre o mundo interno e o externo, porque não consegue diferenciar fantasia de realidade.

Fase de Inversão: após estabelecer a diferença entre si e o outro, a criança consegue tomar o papel deste, experimentando este lugar e, em seguida, não só trocando, mas invertendo, permitindo assim que o outro se 
coloque também no lugar dela. Estabelece assim uma relação mais próxima do real.

FONSECA (1980), partindo das idéias de Moreno e de Martin Buber, oferece descrição apurada das fases da Matriz de Identidade:

Indiferenciação: a idéia quanto à relação a existência do ser humano como ser cósmico ilustra esta fase, em que a criança se encontrase "misturada" com o mundo que a cerca. A criança não sobrevive sozinha e existe a predominância de um sistema interoceptivo, apenas de sensações (fome, frio, dor, desconforto, etc.).

Simbiose: a identidade cósmica inicial vai aos poucos se transformando em vivência de dependência necessária para posteriormente revelar-se em um "eu" e em um "tu". A forte ligação com a mãe caracteriza esta fase tão importante para o surgimento da própria identidade.

Reconhecimento do Eu: existe aqui a atenção concentrada da criança em si mesma, representa uma fase de descobertas graduais de quem é ela e de quem é o outro. É o início de um processo de autoconhecimento e de reconhecimento das sensações cada vez mais complexas e desenvolvidas. É também o momento em que a criança toma consciência do corpo, da imagem. Percebe a separação existente entre seu corpo, o de sua mãe, o de outras pessoas e de objetos.

Reconhecimento do Tu: quando a criança começa a se interessar mais pelos objetos, animais e pessoas que a cercam, descobrindo-os como autônomos e diferentes de si. Ela interage com o mundo, aprendendo através do estabelecimento dos limites e possibilidades dessas relações. 
Para FONSECA (1980), é a partir desta fase discriminatória que as relações poderão evoluir de forma dual, triangular e grupal.

Para MORENO(1993), na passagem do primeiro para o segundo universo, existiria o que chamou de brecha entre fantasia e realidade, ou seja, a diferenciação entre estes dois fenômenos. A partir do reconhecimento do eu, a criança começa a estabelecer as diferenças entre o que é a realidade e o que é sua fantasia. Não se trata de abandonar o mundo de fantasias em prol da realidade, mas poder se transferir de um para o outro, dependendo do momento.

A função da realidade opera mediante interpolações de resistências... impostas por outras pessoas, suas relações, coisas e distâncias no espaço e atos e distâncias no tempo (MORENO, 1993, p. 123).

Resultante desta divisão entre fenômenos reais e fictícios surgem formas de representação derivadas da correlação da criança com pessoas, coisas e tudo o que a cerca no ambiente real e no que ela imagina fazer, ou não, parte de si mesma.

No desenvolvimento da Matriz de Identidade, muitas situações podem ocorrer, gerando dificuldades de relacionamento ou de percepção do mundo real ou imaginário, das pessoas e de seus sentimentos. Tais problemas de desenvolvimento podem ser compreendidos como transtornos e serem diagnosticados. 
FONSECA (2000, p.228), ao abordar Psicodrama e Sexualidade, faz uma análise deste tema e seu desenvolvimento utilizando o referencial de Matriz de Identidade, chamando de "reconhecimento do eu sexual":

Período em que a criança se dá conta do próprio corpo, tomando consciência dos genitais. Percebe a diferença entre os sexos. Realiza a identidade sexual: sou um menino, sou do sexo masculino ou sou uma menina, sou do sexo feminino. A fase do reconhecimento do eu sexual também pode ser chamada fase do espelho sexual. A partir daí se forma a identidade de gênero, compreendida aqui como uma construção social.

Mais adiante, FONSECA (2000, p. 239-240) descreve os transexuais segundo suas identidades existencial, sexual e sexual relacional: Nos transexuais observa-se:

1- $\quad$ Eu sou eu, João.

2- $\quad$ Eu sou eu, João, que apesar de ser menino gostaria de/ou desejo ser menina (Joana).

3- $\quad$ Eu sou eu, João, que apesar de ser menino gostaria de/ou desejo ser menina (Joana), e gosto de fazer coisas de sexo com meninos.

É a partir desta referência que MUTTI et al. (2000) propõe um entendimento psicodramático do transexualismo.

Observando as histórias de vida de seus pacientes, percebem que eles - transexuais masculinos ou femininos - tiveram em seu 
desenvolvimento uma mãe ou figura materna desempenhando o papel de ego-auxiliar na fase de reconhecimento do eu sexual e que era ainda participante ativa na aceitação e estímulo do reconhecimento do eu sexual contrário à sua anatomia. Ou seja, ao filho anatomicamente do sexo masculino, uma aceitação e estímulo a pertencer ao sexo feminino, e viceversa.

Relembrando MORENO (1993), os alicerces do primeiro processo de aprendizagem emocional e sexual da criança são lançados pela Matriz de Identidade. A criança vive no tempo imediato e esta co-existência, co-ação e co-experiência exemplificam a relação do bebê com as pessoas e objetos à sua volta. Particularmente em relação à mãe, seu ego-auxiliar, tudo o que ela faz e preconiza é para a criança como porção inconsciente de seu eu. Aconteça o que acontecer durante o crescimento da criança, esta experiência precoce de identidade modela seu destino.

MUTTI et al. (2000) sugerem que a passagem pela brecha entre a fantasia e a experiência da realidade possibilita à criança estabelecer a posterior tomada de papel do outro e a inversão de papéis. Portanto, o transexualismo pode ser explicado pela impossibilidade de haver ocorrido o estabelecimento da função de realidade, que deveria operar mediante a interpolação de resistências propostas pela mãe que provavelmente não o fez. Sendo assim, não havendo facilitação pelo seu ego-auxiliar (mãe) para vencer essa barreira, pouco adianta a imposição social de uma realidade que não lhe pertence: 
É como se uma parte fundamental de sua existência estivesse deslocada das outras vivências afetivas, sensoriais e perceptivas, e presa a uma figura aceita por seu ego-auxiliar e estimulada por ele.

A construção de uma identidade sexual madura fica prejudicada. Não há superação da brecha entre fantasia e realidade e a estruturação de uma identidade sexual se dá a partir de um eu ilusório, um eu parcialmente diferenciado e reconhecido como verdadeiro por aquele indivíduo, a que gostariamos de chamar de um eu delirante (MUTTI et al, 2000).

A questão leva os autores a pensar que talvez só o desenvolvimento da identidade sexual esteja prejudicado por esta estruturação de um "eu delirante" decorrente de um não-reconhecimento do eu sexual biológico e da não-superação da brecha entre fantasia e realidade devido a um ego-auxiliar deficiente. As questões referentes à orientação sexual e outros aspectos da vida estariam ligadas a fenômenos de identificação e não aos da formação da identidade sexual, exatamente como sugere MORENO (1974) quando se refere à identificação de maneira geral:

"Os mecanismos determinantes da orientação sexual parecem, portanto, serem distintos dos que determinam a identidade sexual, sendo esta primordial e aquela sequencial e autônoma" (MUTTI et al., 2000). 
Alguns pesquisadores, discordantes do que chamam de visão "essencialista" da identidade sexual proposta pelas escolas psicodinâmicas, propõem uma teoria chamada "construcionista" desta identidade (DE CECCO, 1981; PLUMMER, 1981; HART, 1984). Nessa teoria, a identidade sexual é construída a partir de referências sociais e políticas; portanto, "a identidade sexual é lábil e pode ser terapeuticamente modificada" (HART, 1984).

Outras abordagens psicológicas sobre o estabelecimento de identidade sexual seriam as teorias de aprendizado social e de desenvolvimento cognitivo. Diferentemente da psicanálise e do psicodrama, propõem a importância do reforço e dos facilitadores ambientais para que tal comportamento se instale, se manifeste e se mantenha.

As teorias de aprendizado social postulam que o fenômeno de identificação é mesmo válido mas, diferentemente da psicanálise, propõem que a criança apreende e retém os modelos de comportamento expostos pelos pais ou figuras afetivamente importantes, o que induz ou reforça seu comportamento e facilita o fenômeno de identificação com o modelo afetivo. Isso também seria válido para as questões de gênero (KESSLER, MCKENNA, 1978).

Já as teorias de desenvolvimento cognitivo, baseadas na idéias de Piaget, propõem que a criança desenvolve progressivamente a noção de gênero, a qual gênero pertence e sua imutabilidade, podendo aí se identificar com os valores pertencentes ao gênero desenvolvido e a seus 
pais. As noções de diferenças genitais só acontecem após ter se desenvolvido uma identidade de gênero (KESSLER, MCKENNA, 1978).

Vê-se na Tabela 3 um resumo dessas teorias, segundo KESSLER e MCKENNA (1978) :

Tabela 3 - Definição de identidade de gênero segundo diferentes escolas psicológicas

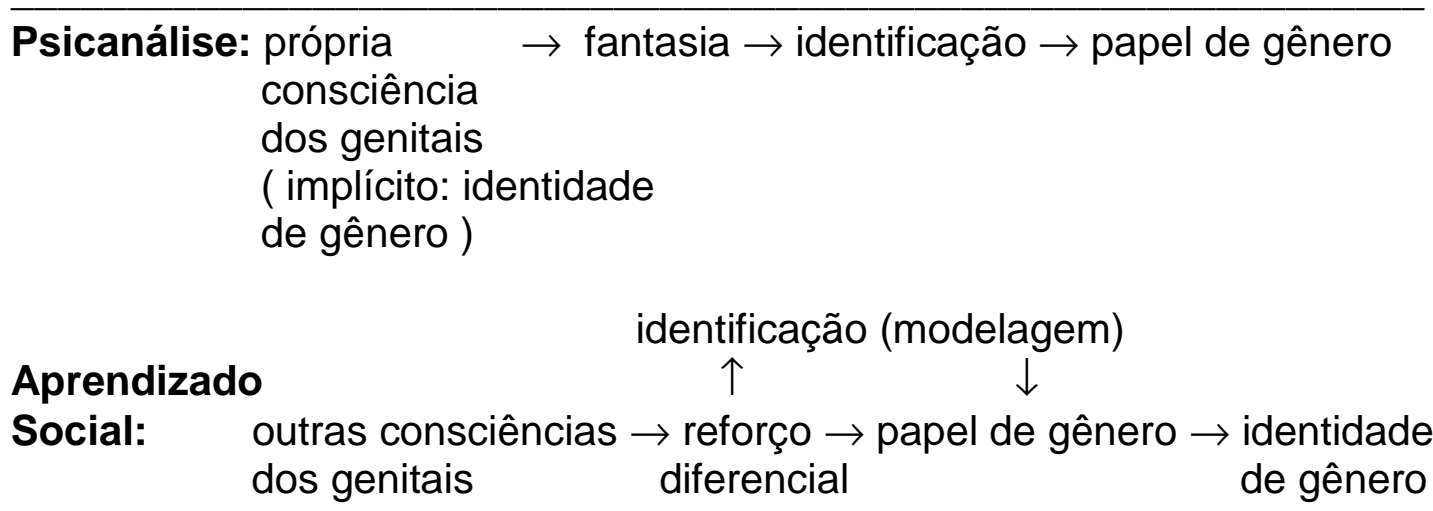

\section{Desenvolvimento}

Cognitivo: outras consciências $\rightarrow$ rotular $\rightarrow$ identidade $\rightarrow$ papel dos genitais de gênero de gênero identificação

\subsection{Prevalência e incidência}

A incidência do transexualismo tende a permanecer a mesma, enquanto a prevalência revela uma variação muito grande desde os primeiros trabalhos a esse respeito até os mais recentes, variando entre países e em época estudada dentro de um mesmo país. Contudo, a razão 
entre transexuais masculinos e femininos se mantém estável em 3:1 independentemente do país ou época (FERREIRA, 2000; BANCROFT, 1989).

No entanto, publicações mais recentes contestam esses números, como mostram dados de prevalência e incidência em vários países e épocas. Vale a pena ressaltar que os dados são sempre para indivíduos maiores de 15 anos.

São exemplos de prevalência estudada o trabalho clássico que PAULY (1968) realizou nos E.U.A.; pesquisa que apresentou números como 1:100.000 de transexuais masculinos e 1:400.000 de transexuais femininos. Já o de WÄLLINDER (1971), realizado na Suécia, revelou números da ordem de 1:37.000 de transexuais masculinos e de 1:103.000 de transexuais femininos. Quanto à incidência anual, WÄLLINDER (1971) aponta números da ordem de 0,20:100.000 e, mais interessante, é a proporção encontrada entre transexuais masculinos e femininos variando de 2,8:1 em 1967 a 1:1 em 1971.

Na Inglaterra e País de Gales, HOENIG e KENNA (1974) encontraram valores como 1,90:100.000 na população, de 1:34.000 de transexuais masculinos e 1:108.000 de transexuais femininos. Já a proporção por sexo é de 3,25:1 de transexuais masculinos em relação aos femininos. A incidência encontrada foi de 0,17-0,26: 100.000 habitantes e a proporção entre homens e mulheres, 1:1.

ROSS et al. (1981) encontraram na Austrália uma prevalência total de 1:42.000, sendo 1:24.000 de transexuais masculinos, 1:150.000 de 
transexuais femininos e uma proporção de 6,1:1 a favor dos transexuais masculinos. Além disso, referem uma incidência de 0,58:100.000 habitantes e uma proporção de 5:1 entre homens e mulheres.

Já em Cingapura os números encontrados por TSOI (1988) foram de 35,2:100.000 no total, de 1:2.900 de transexuais masculinos e 1:8.300 de transexuais femininos, uma proporção de 3:1 a favor dos transexuais masculinos.

$\mathrm{Na}$ Holanda, EKLUND et al. (1988) apresentaram valores de 1:18.000 de transexuais masculinos e 1:54.000 de transexuais femininos e uma proporção de 3:1 de transexuais masculinos em relação aos femininos, o que difere em números absolutos de outra pesquisa realizada no mesmo país por BAKKER et al. (1993), que revelou 1:11.900 transexuais masculinos, 1:30.4000 transexuais femininos e uma proporção de 2,5:1 de transexuais masculinos em relação aos femininos.

Na Alemanha, WEITZE e OSBURG (1996) encontraram números compatíveis com 1:36.000 de transexuais masculinos e 1:94.000 de transexuais femininos. A prevalência total de 1:42.000 e proporção de 2,3:1 de transexuais masculinos em relação aos femininos.

Por fim, na Escócia, WILSON et al. (1999) encontraram números da ordem de 8.18:100.000 de prevalência total de transexualismo e uma proporção de 4:1 de transexuais masculinos em relação aos femininos.

LANDÉN et al. (1996 a), em estudo com duração de 20 anos realizado na Suécia, encontrou uma incidência anual de solicitações para mudança de sexo de 0,17:100.000 habitantes. A proporção de transexuais 
masculinos para femininos foi de 1,4:1 e a incidência de transexualismo primário foi de 0,14:100.000 habitantes, além da proporção ser a mesma para homens e mulheres com esse diagnóstico.

Os autores concluem que a incidência de transexualismo se mantém constante através dos anos e que a incidência de transexualismo primário é a mesma entre homens e mulheres, enquanto que em um grupo maior de solicitantes de redesignação sexual que inclui homossexuais, travestis e outros casos de diagnóstico incerto, os homens predominam.

LANDÉN et al. (1996 b), em trabalho de revisão, discutem as variações encontradas e chegam à conclusão de que:

- a prevalência se encontra próxima dos valores adotados pelo DSM-IV, de 1:30.000 de adultos masculinos e de 1:100.000 de adultos femininos, que buscam cirurgia de redesignação sexual;

- a incidência permanece praticamente a mesma, de 0,15 0,17:100.000 habitantes acima dos 15 anos de idade;

- a proporção entre homens e mulheres varia de 1:1 entre transexuais masculinos e femininos primários até 4:1 entre homens e mulheres de um grupo com diagnóstico incerto;

- a proporção total de pessoas que buscam avaliação para redesignação sexual ficaria por volta de 1,7:1 entre homens e mulheres da amostra geral.

Pelos dados apresentados, vê-se que as conclusões a que LANDÉN et al. (1996 b) chegam, mostram-se consistentes e adequadas a 
uma realidade geral. Contudo, trabalho de HERMAN-JEGLINSKA et al. (2003) afirma que "diferentemente dos países ocidentais, o transexualismo masculino para feminino é muito menos comum que o feminino para masculino" na Polônia, estando na proporção de 1:3,4, ou seja um transexual masculino para 3,4 femininos.

OLSSON e MÖLLER (2003), ao avaliar os pedidos de cirurgias de redesignação sexual na Suécia, no período de julho de 1972 até junho de 2002, encontram dados significativos de que a razão sexual de 1:1 (final dos anos 60) elevou-se para 2:1 (final dos anos 90) em favor dos transexuais masculinos. Atualmente, os transexuais masculinos são seis anos mais velhos que os femininos na época do pedido e oito anos mais velhos do que eram há 20 anos no momento da requisição.

\subsection{Diagnóstico}

O tema é importante para o desenvolvimento de um corpo de conhecimento e desde o século XIX, com as publicações de Von KrafftEbing, merece atenção. À parte a questão etiológica, o diagnóstico e suas dificuldades revelam o quanto ainda deve ser pesquisado a respeito dos transtornos de identidade de gênero. A busca de um método ou instrumento efetivo de elucidação diagnóstica ainda não se mostrou frutífera, o que abre campo para novas e desafiadoras pesquisas. 
A precisão diagnóstica é fundamental para a definição exata de um transtorno de identidade sexual ou de gênero, e mais especificamente para o transexualismo. Isto porque os candidatos a uma cirurgia de redesignação sexual nem sempre são transexuais e nem sempre apresentam melhora na qualidade de vida com a cirurgia, além de ser irreversível em muitos casos e em outros, de difícil reversão (TULLY, 1992).

SCHAEFER e WHEELER (1995), ao estudar os 10 primeiros casos de transexualismo de Harry Benjamin, relatam que, assim como hoje, os pacientes Ihe chegavam autodiagnosticados e descrevem características que se parecem com as dos atuais pacientes:

- $\quad$ o reconhecimento da condição muito cedo em suas vidas;

- $\quad$ tentativas de transvestismo;

- $\quad$ presença de sigilo;

- $\quad$ a culpa intensa e presente;

- $\quad$ tentativas frustradas de suprimir desejos e sentimentos;

- $\quad$ a episódica e contínua expiação.

MONEY (1988), na tentativa de facilitar o entendimento, descreve: A síndrome de transexualismo é também conhecida como uma disforia de gênero, de acordo com um sistema de nomenclatura que é baseado em conceitos que o paciente tem de seus próprios sentimentos e convicções, e como uma alternativa de evidência mais empírica e objetiva.

Disforia de gênero e transexualismo não são perfeitamente sinônimos pois existem muitos pacientes com disforia de 
gênero que não são transexuais e não desejam a cirurgia de redesignação sexual.

Aliás, expressões como disforia de gênero, transtorno de identidade de gênero e transtorno de identidade sexual foram e ainda são utilizados como sinônimos, designando uma síndrome, sendo o transexualismo uma das possibilidades diagnósticas desta síndrome.

FISK (1973) é quem descreve a Síndrome de Disforia de Gênero para um grupo heterogêneo de indivíduos que não deve ser classificado como transexuais. O termo transexual deve se restringir a um grupo de indivíduos que, sem ser psicótico, mostra intenso desconforto com seu sexo anatômico e expressa forte desejo e busca intensa de mudança de gênero. A síndrome, segundo o autor, pode ser subdividida em cinco entidades clínicas, além do transexualismo:

- tipo homossexual afeminado;

- tipo transvéstico;

- tipo personalidade esquizóide-inadequada;

- categoria de psicose em remissão;

- $\quad$ tipo exibicionista-sociopático.

PERSON e OVESEY (1974), psicanalistas, em um esforço por identificar as diferentes populações que buscam a cirurgia de redesignação sexual, descrevem o que chamam de transexualismo primário e transexualismo secundário, como duas variantes clínicas. O transexualismo primário apresenta os núcleos de identidade e papel de gênero alterados desde a infância e progride insistentemente até a cirurgia de redesignação 
sexual. Já o transexualismo secundário manifesta-se em indivíduos ativos sexualmente, sendo homossexuais afeminados ou travestis que apresentam uma regressão psíquica em situações de estresse e buscam a cirurgia de redesignação sexual.

STOLLER (1974) distingue transexualismo verdadeiro de nãotransexuais utilizando basicamente os mesmos critérios acima expostos.

DEROGATIS et al. (1978) em um trabalho hoje clássico sobre transexualismo masculino encontram as seguintes características dessa população de 31 componentes, comparadas a um grupo de controle heterossexual masculino composto de 57 pessoas:

- Transexuais têm experiências sexuais limitadas quando comparados com uma população heterossexual masculina. Existiria até um sub-grupo transexual masculino que pode ser chamado de "assexual", ou seja, desinteressado de qualquer atividade sexual;

- Masturbação não varia estatisticamente em freqüência entre os dois grupos;

- Transexuais masculinos são pessoas rígidas, moralistas e isoladas;

- Foram encontrados elevados níveis de depressão e ansiedade, com significante auto-depreciação, comportamentos agorafóbicos e um marcante sentido de alienação;

- Transexuais sofrem de uma redução geral de afetos positivos, bem como de altos níveis de emoções negativas; 
- A presença de uma anedonia importante e condizente com os níveis de depressão pode servir de base para uma mensuração do ajustamento pós-cirúrgico.

Já em 1981, DEROGATIS et al., repetindo o mesmo tipo de pesquisa, porém com 20 transexuais femininos, comparados a uma população feminina heterossexual de 143 pessoas, encontram os seguintes resultados:

- Apesar de dois terços dela revelarem relações sexuais íntimas com homens em algum momento de suas vidas, há baixa atividade sexual presente nessa população;

- Não há diferenças significativas entre transexuais femininas e heterossexuais femininas nos quesitos masturbação e fantasias sexuais;

- Não apresentam disforia em níveis dramáticos, apesar de apresentarem afeto depressivo;

- Geralmente o papel de gênero é bem desenvolvido e desempenhado. Passam relativamente bem por homens e têm ocupações masculinas. Isso acontece com mais facilidade nesse grupo, do que no grupo de transexuais masculinos, no qual passar por mulher e ter atividade feminina é bem mais difícil.

LEVINE e LOTHSTEIN (1981) fazem uma sistematização teórica sobre o tema a fim de organizar o conhecimento nessa época, em que havia:

- $\quad$ confusão de termos, caracterizações e diagnósticos; 
- discussão em torno da aceitação do termo disforia de gênero ou na perpetuação da expressão transexualismo;

- revisão da influência da visão psicanalítica a respeito do assunto;

- questionamentos referentes a ser uma síndrome ou uma patologia isolada;

- indicação cirúrgica para todos os solicitantes, ou não.

Retomando a postura de STOLLER (1969), que entendia o transexualismo como um sintoma e não um transtorno, LEVINE e LOTHSTEIN (1981) fazem as seguintes objeções ao uso do termo transexualismo:

A expressão "síndrome de disforia de gênero" é preferida como diagnóstico pela maioria dos clínicos em detrimento do termo transexualismo;

Transexualismo é um diagnóstico feito pelo próprio paciente e é notório que em medicina o auto-diagnóstico não deve ser aceito. A mídia criou a ilusão de que o transexualismo é bem definido, é uma entidade psiquiátrica única e só pode ser tratado com a cirurgia de redesignação sexual;

Transexualismo é utilizado para descrever três fenômenos relacionados, mas que seriam melhor descritos de outra maneira: o desejo de se tornar membro do sexo oposto; viver no papel de gênero contrário ao seu; "status" pós-cirurgia de redesignação sexual; 
- $\quad$ Mesmo fazendo uso de hormônios, vivendo no papel de gênero oposto e realizando a cirurgia de mudança de sexo, não é possível a mudança genética e a experiência psicológica. Para efeitos de precisão, o termo transexualismo deveria ser mudado para transgenderismo, porque o problema é de identidade de gênero, não de anatomia genital;

Nos anos 70 ficou evidente que uma série de diferentes pacientes buscavam a cirurgia de redesignação sexual. A manutenção do termo transexualismo pelo DSM-III justifica-se pelo uso e referência que a expressão tem em relação aos transtornos de identidade de gênero para os profissionais de saúde e de lei.

Os mesmos autores propõem 0 seguinte esquema para a caracterização do quadro e unificação terminológica:

\section{A: Diagnóstico de gênero para homens com Síndrome de Disforia de Gênero:}

Disforia de Gênero Primária: desde a infância; não relacionado ao estresse; sem sinais de fetichismo; experiências homossexuais curtas, se é que existem e servindo apenas para confirmar que não pertencem a essa categoria; uma minoria dos pacientes que buscam a cirurgia pertencem a essa classificação ( $10 \%-25 \%$ do total).

Disforia de Gênero Secundária: relacionada ao estresse; desejam a cirurgia intensamente e se estressam com a demora; apresentam traços 
masculinos em sua adaptação e conflitos intrapsíquicos que revelam regressão e instabilidade. Podem ser subdivida em:

Adaptação Transvéstica;

Adaptação Homossexual Efeminada;

Adaptação de Identidade de Gênero Ambígüa;

Adaptação Mista.

B: Diagnóstico de gênero para mulheres com Síndrome de Disforia de Gênero:

Disforia de Gênero Primária: a grande maioria; ativa no desempenho de esportes; sofrimento surge na puberdade com o surgimento das características sexuais secundárias; apaixonam-se por garotas heterossexuais.

Disforia de Gênero Secundária: raras ou pouco comuns; as características aparecem mais tarde que na primária; fantasias seguidas de culpa; vêm de locais homofóbicos e têm dificuldades em aceitar o papel homossexual. Podem ser subdividas em:

Adaptação Homossexual;

Adaptação de Gênero Ambígüo;

Adaptação Mista.

Como se pode perceber, as variações são mínimas entre os conceitos de transexualismo primário ou verdadeiro e disforia de gênero primária. O mesmo acontece quanto aos conceitos de transexualismo secundário e disforia de gênero secundária. O que se evidencia é um 
distanciamento do uso do termo transexualismo pelos motivos anteriormente expostos por LEVINE e LOTHSTEIN (1981).

SORENSEN e HERTOFT (1982), em extenso trabalho realizado na Dinamarca, caracterizam fenomenologicamente a população transexual como tendo um traço predominante de insegurança básica na identidade de gênero desde a infância. Diferenciam, ainda, os transexuais masculinos e femininos pelas següintes carcterísticas:

- Transexualismo masculino: regressão narcísica para uma condição acentuada de submissão e pseudo-feminilidade. Presença de ansiedade e insegurança, relativizadas em significado pela presença de fantasias e pela supressão de sentimentos agressivos e sexuais. Isso resulta em pseudofeminilidade;

- Transexualismo feminino: presença de atitudes fálicas e narcísicas, além de maneirismos masculinos na tentativa de diminuir sua insegurança.

Além disso, os autores afirmam que transexuais femininas são muito mais ativas sexualmente, que transexuais masculinos. Encontram ainda maior conexão entre homossexualidade e transexualismo feminino do que entre homossexualidade e transexualismo masculino.

ROBERTO (1983), em trabalho hoje considerado clássico, discute critérios diagnósticos e tratamentos propostos para o que chama de transexualismo e seus sub-grupos. Identifica o transexualismo pelo següinte conjunto de características: 
- Crença de que é membro do sexo oposto;

- Veste-se e apresenta-se no papel de gênero oposto;

- Percebe-se como heterossexual, apesar dos parceiros serem anatomicamente idênticos a ele;

- Repugnância por seus próprios genitais e desejo de transformá-los;

- História de transvestismo;

- Desejo persistente pela cirurgia de conversão sexual.

A autora acrescenta história de transtorno de gênero na infância, mesmo considerando que nos estudos de seguimento longitudinal de crianças com desvio de gênero, apenas uma parte evolui para transexualismo e não é claro quais as características desse desvio na infância que podem levar ao transexualismo na fase adulta. Complementa afirmando que parte evoluirá para homossexualidade conflitiva, outra, para transvestismo e uma outra, para condições sem conflitos psicológicos.

Conclui que essa não é uma síndrome unitária, não possuindo métodos irrefutáveis de avaliação, na qual o diagnóstico ainda se baseia na entrevista clínica e a proposta de tratamento não é unânime.

DAVENPORT (1986), em estudo de seguimento de oito a 10 anos com garotos afeminados, que hoje poderiam ser considerados como com transtorno de identidade de gênero na infância, considera que nem todos evoluem para 0 transexualismo. Dos 10 garotos, quatro tornaram-se heterossexuais; dois, homossexuais; um, transexual e três, incertos quanto à identidade e/ou orientação. Termina afirmando que "a força, rigidez e 
persistência do comportamento relacionado ao transvestismo durante a fase de latência pode ser bom indicador de transexualismo".

BLANCHARD et al. (1987), estudando pacientes com disforia de gênero heterossexuais e homossexuais, tanto masculinos quanto femininos, afirmam que o "transexualismo pode ser definido como uma disforia de gênero extrema que persiste pelo menos por um ou dois anos, sem flutuação".

DOLAN (1987), preocupado e interessado em especificar os diagnósticos, visando o tratamento em seqüência, avalia 350 pacientes num período de cinco anos em Toronto e propõe que se utilizem os següintes termos, com base na classificação de Transexualismo do DSM-III (APA, 1980): Transexualismo Verdadeiro ou Primário (masculino ou feminino) e Transexualismo Secundário (Síndrome de Disforia de Gênero - masculino ou feminino).

O DSM-III (APA,1980) especifica para o diagnóstico de transexualismo cinco características:

A - sensação de desconforto e inadequação ao seu próprio sexo anatômico;

$B$ - desejo de ter seus genitais eliminados e viver como membro do sexo oposto;

C - transtorno contínuo (não limitado a períodos de estresse) por, no mínimo, dois anos;

D - ausência de anormalidade física interssexual ou genética;

E - não devido a outro transtorno mental, tal como esquizofrenia. 
DOLAN (1987), partindo dessa especificação diagnóstica, estabelece as características essenciais para o diagnóstico de transexualismo primário ou verdadeiro (Tabela 4).

Tabela 4 - Transexualismo primário (verdadeiro) - Dolan - 1987

\section{PERFIL}

Masculino/Feminino Feminino/Masculino

Transvestismo

durante a vida

(desejo e comportamento)

Erro de gênero

Transvestismo:

antes da adolescência:

depois da adolescência:

Excitação fetichista

em vestir ou fantasia

Ativo sexualmente

+/- + +/-

Heterogenderismo

(homoerótico)

Comportamento

retraído/antissocial

Pode fisicamente passar

pelo gênero oposto:

sem hormônios:

sem eletrólise:

com voz aceitável:

Interage e projeta imagem

do gênero oposto apesar

do estado biológico

$\begin{array}{ll}+ & + \\ + & + \\ + & +\end{array}$

$+: \operatorname{sim} \quad-:$ não 
DOCTER (1990) na tentativa de diferenciar as populações que se transvestem, publica um livro no qual aborda populações específicas e suas características, visando à particularização e discussão das indicações cirúrgicas em suas especificidades. As populações que se transvestem podem ser divididas em dois grandes grupos: as que apresentam padrões de comportamento heterossexual envolvendo transvestismo (cinco subgrupos) e as que revelam padrões de comportamento homossexual envolvendo transvestismo (outros quatro subgrupos). Resumidamente, segundo o autor, tem-se:

A: Padrões de comportamento heterossexual com transvestismo:

1. Fetichismo: transvestismo é parcial, nunca completo; o objetivo é a excitação sexual; não tenta se passar por indivíduo do outro gênero em público; não apresenta problemas com sua identidade de gênero; obtendo o orgasmo, abandona o estímulo, mesmo que temporariamente; corresponde ao tipo 1, "pseudo-travesti", de Harry Benjamin.

2. Transvestismo fetichista: história de forte excitação sexual com o transvestismo; mais fortemente de orientação heterossexual do que o grupo de transvestismo marginal; uma história mais forte de ajustamento pessoal do que o grupo marginal; menor discordância de gênero que os indivíduos de transvestismo marginal; identidade de gênero é facilitada pelo transvestismo, mas é egossintônica; raramente elegem uso de hormônios por longo tempo para a feminilização; não buscam cirurgias 
adaptativas ou de redesignação sexual; nunca vivem o tempo todo como mulher: o transvestismo é periódico; ser reconhecido como mulher em público é altamente valorizado.

3. Transvestismo marginal: história de excitação sexual com o transvestismo; orientação heterossexual mais fraca que no grupo fetichista; possível preferência homossexual ou bissexual; sentimentos persistentes de disforia de gênero; procura e consegue terapia hormonal para feminilização; procura informação a respeito das possíveis etapas transexuais; experimenta viver como transgênero, sem sê-lo; procura transexuais como mentores, modelos ou tutores; valoriza o casamento menos que o grupo fetichista, mas mais que os trangêneros; transvestismo é periódico.

4. transgênero: muito próximo do grupo marginal; vive o tempo todo transvestido e no papel de gênero contrário, porém na ausência da cirurgia de redesignação sexual e podendo oscilar entre um papel de gênero e outro; se não oscila, pode ser enquadrado como transexual pelos critérios estabelecidos; podem ter orientação hetero, homo ou bissexual; podem ser considerados como em transição para transexualismo secundário; faz uso de hormonioterapia e cirurgias cosmésticas e dentárias.

5. Transexualismo secundário ( tipo transvéstico): história de alguma excitação sexual em se transvestir; progressiva história 
de forte disforia de gênero relacionada a estresse; menor integração egóica que em travestis; procura cirurgia de redesignação sexual após tempo como travesti; ausência de disforia de gênero ao longo de toda a vida; vive o tempo todo no papel de gênero contrário ao de seu nascimento, com ou sem cirurgia de redesignação sexual; fortes padrões de personalidade narcísica ou "borderline".

B: Padrões de comportamento homossexual com transvestismo:

1. Transexualismo primário: disforia de gênero presente durante toda a vida; história de identidade de gênero trocada; ausência de fetichismo associada ao transvestismo; raízes profundas na infância de descontentamento com seu gênero de origem; preferência sexual é usualmente homossexual desde a mais tenra idade; história longa de transvestismo.

2. Transexualismo secundário (tipo homossexual): menos conhecida do que outras categorias; história de vida homossexual, sem transvestismo e na ausência de uma disforia de gênero prolongada; essa variação também é vista como resposta relacionada ao estresse; fortes padrões de características de personalidade narcísica ou "borderline".

3. "Drag-queens": gíria para designar homens transvestidos que se prostituem; este subgrupo está ligado à questão da 
prostituição e criminalidade (uso de drogas, assaltos, furtos e, inclusive, assassinatos).

4. "Female impersonators" (transformistas): homossexuais; gostam do transvestismo e podem viver como mulheres durante bom tempo, mas não é comum; trabalham na periferia do "show business"; sentem-se mais confortáveis no papel feminino; muitos apresentam em suas histórias variações de ajustamento de personalidade e comportamentos maladaptativos.

BROWN (1990), abandonando os termos transexualismo verdadeiro ou primário e transexualismo falso ou secundário, adota disforia de gênero. Preocupado com os diagnósticos diferenciais dentro desse grupo, em sua opinião, "heterogêneo", propõe que a anamnese seja muito bem feita e que a relação médico-paciente seja empática, evitando irritação, não se deixando convencer pelo auto-diagnóstico que esses pacientes fazem. Avaliação diagnóstica extensa, levando em consideração familiares, é importante, além da persistência de transvestismo por parte do paciente. $O$ diagnóstico diferencial dentro do grupo de Disforia de Gênero é fundamental para uma indicação terapêutica eficaz.

LEVINE (1993), em trabalho seminal a respeito de homens com distúrbios de gênero, afirma:

As confusas diferenças entre homens que se vestem de mulher podem ser explicadas por suas diversidades ao longo de três dimensões: 1) a ambição de intercurso heterossexual; 2) história natural de sua excitação 
sexual por roupas femininas; 3) capacidade atual de integrar seus empenhos masculino e feminino em diferentes compartimentos. Quando um indivíduo que usa roupas do outro sexo, abandona todos os vestígios dos comportamentos de papel de gênero masculino e, com sucesso, vive e trabalha o tempo todo como mulher, o termo descritivo e apropriado para eles é o de "transexual".

Um subgrupo distinto é descrito por BLANCHARD (1994): o de disforia de gênero masculina não-homossexual. Sob essa denominação estão incluídos os indivíduos que são sexualmente atraídos por mulheres, pelos dois sexos ou por nenhum. Geralmente se casam e têm filhos e só procuram ajuda clínica por volta dos 30 anos, não raro entre 50 e 60 anos. Não fica clara a importância nosológica desse grupo, talvez como transexualismo secundário a ser avaliado.

O mesmo se dá em trabalho de DICKEY e STEPHENS (1995), no qual fazem a descrição do que chamam de subtipo de "gênero-disfóricas e geneticamente mulheres atraídas sexualmente por indivíduos fenotipicamente masculinos". Na realidade seriam transexuais femininas cuja atração básica é por homens.

CHIVERS e BAILEY (2000) encontram transexuais femininas heterossexuais e homossexuais, compondo o grande grupo de transexualismo feminino. Apesar de apresentarem diferenças em suas histórias de vida em relação a número de parceiros, infância e ciúmes, não diferem quanto ao desejo de masculinização do corpo, identidade de gênero adulta, beleza física e juventude. 
HYDE (1994) e LANDÉN et al. (1996) definem transexual como aquele que acredita que ele/ela está aprisionado em um corpo de outro gênero. Entendem o termo como sinônimo de disforia de gênero, cujo conceito seria o de "infelicidade ou insatisfação com seu próprio gênero".

DOORN et al. (1994) investigam as diferenças e a possível evolução desde um paciente caracterizado como travesti até um transexual verdadeiro ou primário.

Eles propõem dois subsistemas de identidade de gênero, um masculino e outro feminino presentes em qualquer ser humano. Um percorreria desde forte e incondicional expressão de identidade de gênero feminina até fraca e inexpressiva femininlidade. $O$ outro percorreria desde forte e incondicional expressão de masculinidade até fraca e incondicional masculinidade. Esquematicamente, tem-se para a população masculina estudada:

Feminilidade forte e incondicionalmente expressa

\begin{tabular}{l|l}
$\begin{array}{l}\text { Masculinidade } \\
\text { forte e incondicionalmente } \\
\text { expressa }\end{array}$ & $\begin{array}{c}\text { TS masculinos e mulheres } \\
\text { Masculinidade } \\
\text { fraca e condicionalmente } \\
\text { expressa } \\
\text { TV masculinos }\end{array}$
\end{tabular}

Feminilidade fraca e condicionalmente expressa

TV: travestis

TS: transexuais

Como comparação, CUYPERE et al. (1995) estabelecem diferenças sociodemográficas e psicopatológicas entre transexuais masculinos e 
femininos. Em termos sociodemográficos, encontram maior homogeneidade nos transexuais femininos. Consideram que os dois grupos apresentam sinais de problemas psíquicos, porém sendo os transexuais masculinos mais doentes.

COHEN-KETTENIS e GOOREN (1999), pesquisadores holandeses, em grande revisão sobre etiologia, diagnóstico e tratamento, dizem que "disforia de gênero é o termo para o sofrimento resultante do conflito entre identidade de gênero e o sexo de nascimento".

Acrescentam que presentemente é impossível diagnosticar transexualismo com base em critérios objetivos por que não existem métodos psicométricos ou instrumentos psicológicos para medir transexualismo. O diagnóstico depende das informações subjetivas dadas pelos solicitantes de diagnóstico.

Propõem, baseados nos padrões de tratamento da Associação Internacional Harry Benjamin de Disforia de Gênero, que o diagnóstico seja realizado em duas etapas. A primeira consiste em fazer o diagnóstico baseado em critérios formais psiquiátricos (DSM-IV ou CID-10). Na segunda, é testada a capacidade de um indivíduo que solicite a cirurgia em viver no papel de gênero desejado e a real força de vontade para a cirurgia de redesignação sexual, face ao desapontamento enquanto vive no papel de gênero oposto.

DOCTER e FLEMING (2001) estudando 455 travestis e 61 transexuais masculinos com o objetivo de caracterizar essas populações, identificam e interpretam cinco fatores, com respeito aos parceiros sexuais 
preferidos e usuais: identidade transgênero, papel, excitação sexual, sedução masculina e prazer. Os transexuais apresentam maiores valores para os fatores I (identidade), II (papel) e IV (sedução masculina); já os travestis paresentam maiores valores para os fatores III (excitação sexual) e V (prazer). Concluem sugerindo que a análise desses fatores pode contribuir na diferenciação desses dois subgrupos de transgêneros.

Pelo já explicitado, três referências são consideradas pela maioria dos autores em relação ao diagnóstico de transexualismo, transtorno de identidade sexual, transtorno de gênero, disforia de gênero, ou o nome que se escolha dar ao transtorno:

1. Classificação Internacional de Doenças, $10^{\underline{a}}$ versão (CID-10) (OMS, 1993);

2. Manual Diagnóstico e Estatístico de Transtornos Mentais, 4a edição - Diagnostic and Statistical Manual of Mental Disorders, 4th edition; DSM-IV - (APA, 1995) e sua revisão de texto, Diagnostic and Statistical Manual of Mental Disorders, 4th edition, text revision; DSM-IV-TR (APA, 2000);

3. The Harry Benjamin International Gender Dysphoria Association's, Standards of Care for Gender Identity Disorders, 6th version (HBIGDA, 2001) - Associação Internacional Harry Benjamin de Disforia de Gênero, Padrões de Cuidados para Transtornos de Identidade de Gênero, 6 versão (HBIGDA, 2001). 
O manual CID-10 (OMS, 1993, p. 210-211) estabelece dentro dos Transtornos de Personalidade e Comportamento em adultos (F60 - F69), como categoria à parte, os Transtornos de Identidade Sexual (F64). Nessa categoria encontram-se como possibilidades diagnósticas:

F64.0 Transexualismo:

Um desejo de viver e ser aceito como um membro do sexo oposto, usualmente acompanhado por uma sensação de desconforto ou impropriedade de seu próprio sexo anatômico e um desejo de se submeter a tratamento hormonal e cirurgia para tornar seu corpo tão congruente quanto possível com o sexo preferido.

Diretrizes Diagnósticas: Para que esse diagnóstico seja feito, a identidade transexual deve ter estado presente persistentemente por pelo menos 2 anos e não deve ser um sintoma de um outro transtorno mental, tal como esquizofrenia, nem estar associada a qualquer anormalidade intersexual, genética ou do cromossomo sexual.

F64.1 Transvestismo de duplo papel:

O uso de roupas do sexo oposto durante parte da existência para desfrutar a experiência temporária de ser membro do sexo oposto, mas sem qualquer desejo de uma mudança de sexo mais permanente ou de redesignação sexual 
cirúrgica associada. Nenhuma excitação sexual acompanha a troca de roupas, o que distingue o transtorno de transvestismo fetichista (F65.1).

Inclui: transtorno de identidade sexual da adolescência ou da idade adulta, tipo não transexual.

Exclui: transvestismo fetichista (F65.1).

Outros transtornos de identidade sexual classificados na CID-10, mas sem importância conceitual com o tema, são:

F64.2 Transtornos de identidade sexual na infância;

F64.8 Outros transtornos de identidade sexual;

F64.9 Transtorno de identidade sexual, não especificado.

Como se pode perceber, a CID-10 mantém o uso do termo transexualismo, define-o como transtorno de identidade sexual e o diferencia do transvestismo de duplo-papel e do transvestismo fetichista, que são duas categorias passíveis de confusão. O transexualismo para a CID-10 corresponde ao transexualismo verdadeiro ou primário e o secundário, e os outros diagnósticos são diferenciais.

Já o DSM-IV e o DSM-IV-TR (APA, 1995, p. 241-243; APA, 2000, p. 576-582) classificam o quadro de forma semelhante, mas com diferenças marcantes em relação à CID-10: 
Transtorno de Identidade de Gênero:

A. Uma forte e persistente identificação com o gênero oposto (não meramente um desejo de obter quaisquer vantagens culturais percebidas pelo fato de ser do sexo oposto).

Em crianças, a perturbação é manifestada por quatro (ou mais) dos seguintes quesitos:

(1) declarou repetidamente o desejo de ser, ou insistência de que é, do sexo oposto;

(2) em meninos, preferência pelo uso de roupas do gênero oposto ou simulação de trajes femininos; em meninas, insistência em usar apenas roupas estereotipadamente masculinas;

(3) preferências intensas e persistentes por papéis do sexo oposto em brincadeiras de faz-de-conta, ou fantasias persistentes acerca de ser do sexo oposto;

(4) intenso desejo de participar em jogos e passatempos estereotípicos do sexo oposto;

(5) forte preferência por companheiros do sexo oposto.

Em adolescentes e adultos, o distúrbio se manifesta por sintomas tais como desejo declarado de ser do sexo oposto, passar-se freqüentemente por alguém do sexo oposto, desejo de viver ou ser tratado como alguém do sexo oposto, ou a 
convicção de ter os sentimentos e reações típicos do sexo oposto.

B. Desconforto persistente com seu sexo ou sentimento de inadequação no papel de gênero deste sexo.

Em crianças, a perturbação manifesta-se por qualquer das seguintes formas: em meninos, afirmação de que seu pênis ou testículos são repulsivos ou desaparecerão, declaração de que seria melhor não ter um pênis ou aversão a brincadeiras rudes e rejeição a brinquedos, jogos e atividades estereotipadamente masculinos; em meninas, rejeição a urinar sentada, afirmação de que desenvolverá um pênis, afirmação de que não deseja desenvolver seios ou menstruar ou acentuada aversão a roupas caracteristicamente femininas.

Em adolescentes e adultos, o distúrbio manifesta-se por sintomas tais como preocupação em ver-se livre de características sexuais primárias ou secundárias (por ex., solicitação de hormônios, cirurgia ou outros procedimentos para alterar fisicamente as características sexuais, com 0 objetivo de simular o sexo oposto) ou crença de ter nascido com o sexo errado.

C. A perturbação não é concomitante a uma condição intersexual física. 
D. A perturbação causa sofrimento clinicamente significativo ou prejuízo no funcionamento social ou ocupacional ou em outras áreas importantes da vida do indivíduo.

Codificar com base na idade atual:

302.6 Transtorno da identidade de gênero em crianças;

302.85 Transtorno da identidade de gênero em adolescentes ou adultos.

Especificar se (para indivíduos sexualmente maduros):

Atração sexual por homens;

Atração sexual por mulheres;

Atração sexual por ambos os sexos;

Ausência de atração sexual por quaisquer dos sexos.

Além dessa classificação, existe a Categoria 302.6: Transtorno da Identidade de Gênero, sem outra especificação.

Esta categoria é incluída para a codificação de transtornos da identidade de gênero não classificáveis como um Transtorno da Identidade de Gênero específico. Exemplos:

1. Condições intersexuais (por ex., síndrome de insensibilidade a andrógenos ou hiperplasia adrenal congênita) e disforia concomitante quanto ao gênero.

2. Comportamento transvéstico transitório, relacionado ao estresse. 
3. Preocupação persistente com castração ou penectomia, sem um desejo de adquirir as características sexuais do gênero oposto.

Comparando as duas classificações, observa-se que na CID-10 é mantido o termo transexualismo e os transtornos de identidade sexuais na infância são catalogados em separado. O transvestismo de duplo-papel também é considerado e categorizado separadamente. Já no DSM-IV e DSM-IV-TR existe apenas o transtorno de identidade de gênero, esse, sim, a ser classificado em crianças ou adolescentes e adultos. Nessa classificação percebe-se o abandono do uso do termo transexualismo e a possibilidade de um indivíduo portador de transtorno de gênero poder sentir atração sexual por quaisquer dos sexos ou, inclusive, por ambos.

BRADLEY et al. (1991) justifica a exclusão do termo transexualismo e a inclusão do termo transtorno de identidade de gênero em sentido mais amplo do uso, visando a uma homogeneização dos conceitos e retirando a visão já carregada do termo transexualismo. Além disso, reconhece as possibilidades de diferentes orientações sexuais dentro de um mesmo grupo de transtorno de identidade de gênero.

A nomenclatura e critérios adotados pela American Psychiatric Association na elaboração do DSM-IV são importante referência, até mesmo pelos questionamentos e críticas levantadas por alguns pesquisadores.

MORMONT et al. (2001), por exemplo, criticam o fato do DSM-IV adotar a visão de que a diferença entre transexuais e outras formas de disforia de gênero pode ser interessante critério diferencial, embora casos 
altamente heterogêneos sejam reagrupados em conjunto nessa classificação.

BOWER (2001) critica enfaticamente determinados pontos do texto do DSM-IV, desde os números apresentados como prevalência, passando pela afirmação da não-necessidade de exames subsidiários (cariótipo, cromossomos sexuais etc.), até a pobreza dos diagnósticos diferenciais. Enfatiza que, apesar dessas questões, é uma classificação adequada para os transtornos de identidade de gênero, mas que pode e deve ser melhorada, pois possui critérios que podem impedir o diagnóstico correto.

Insiste na questão de que o diagnóstico emerge durante o processo que ele chama de "entrevista clínica" e que a decisão cirúrgica deve ser tomada apenas após longo e extenso período de observação, levando em conta variáveis específicas, como adoção do gênero de maneira integral, adequação ao gênero desejado, e outros. Finaliza dizendo que gostaria que os procedimentos diagnósticos e de decisão cirúrgica fossem objetivos e científicos, mas reconhece que ainda não atingiram esse patamar.

A terceira e última fundamental referência diagnóstica, a The Harry Benjamin International Gender Dysphoria Association's, Standards of Care for Gender Identity Disorders, 6th version (HBIGDA, 2001) - Associação Internacional Harry Benjamin de Disforia de Gênero, Padrões de Cuidados para Transtornos de Identidade de Gênero, 6ª versão (HBIGDA, 2001) - em seus conceitos introdutórios, deixa claro que o maior propósito dos Padrões de Cuidados para Transtornos de Identidade de Gênero é articular o consenso de organizações profissionais internacionais a respeito das 
características de manejo e tratamento psiquiátricas, psicológicas, médicas e cirúrgicas dos transtornos de identidade de gênero.

No capítulo sobre considerações epidemiológicas, discorda dos valores apresentados pelo DSM-IV e afirma, com base em pesquisa recente holandesa que a prevalência do transexualismo, entendido como o final do espectro dos transtornos de identidade de gênero, é de 1:11.900 para homens e 1:30.400 para mulheres.

Em termos diagnósticos há pouco a acrescentar, sendo valorizados os critérios do DSM-IV e da CID-10. Ressalva que o termo "transgênero" não serve de diagnóstico pois é usado sem a conotação psicopatológica por pessoas e profissionais. O sentido é sobretudo o de informalmente caracterizar pessoas com identidades de gênero pouco usuais (HBIGDA, 2001).

Terminada a revisão bibliográfica a respeito da questão diagnóstica, em síntese das variadas posições dos pesquisadores estabelece-se:

1. coexistência nos últimos anos de vários termos referentes aos transtornos de identidade de gênero;

2. progressivo movimento em direção ao abandono do termo transexualismo, que nada mais seria que um extremo do espectro de transtorno de identidade de gênero;

3. consenso no uso tanto da CID-10 (OMS, 1993) quanto do DSM-IV (APA, 1995) nos critérios diagnósticos dos transtornos de identidade de gênero; 
4. opção cada vez maior e mais clara pelo uso do termo transtorno de identidade de gênero em lugar de transtorno de identidade sexual, visto que sexo seria mais restrito às características anatômicas e biológicas e gênero envolveria construção psicológica e social;

5. abandono do termo disforia de gênero, pela pouca especificidade;

6. restrição do uso do termo transgênero ao meio social e informal, não ao médico-psicológico e científico.

Pelo exposto, vê-se a dificuldade que atualmente se encontra em estabelecer o diagnóstico preciso de transexualismo, ou mesmo de transtorno de identidade de gênero, com características específicas e únicas. Muitas pesquisas mais recentes buscam revelar o grau de masculinidade ou feminilidade nessas populações e nesses pacientes como um possível fator facilitador do diagnóstico (LIPPA, 2001; HERMANJEGLINSKA et al., 2003).

Por fim, fazendo um apanhado consistente de todo o histórico da dificuldade diagnóstica e entendendo o transexualismo como transtorno mental que deve ser diagnosticado e tratado como tal, utilizam-se os seguintes critérios para defini-lo:

Anamnese: história desde a infância de inadequação de gênero; quadro não relacionado à situação de estresse; ausência de sinais de fetichismo; experiências homossexuais raras e geralmente na fase de definição pessoal, quando 
descobre que a categoria homossexual não the é adequada; vivência no gênero desejado sem conflitos; crença de que é heterossexual e de que é membro do gênero oposto ao seu sexo anatômico; busca a transformação hormonal e cirúrgica; mostra repugnância por seus genitais e vontade de transformálos; grande sofrimento psíquico por sua situação com sintomas depressivos e história de auto-agressão, até mesmo suicídio. Desconforto e inadequação de gênero com duração de no mínimo dois anos;

- Vivência no papel de gênero desejado já estabelecida ou a se estabelecer durante o acompanhamento;

- Ausência de anormalidades genéticas ou interssexual;

- Não decorrente de quadro esquizofrênico, transtorno de humor psicótico, transtorno mental orgânico ou oligofrenia;

- Busca real e intensa pela cirurgia, mas com a compreensão das dificuldades presentes na indicação desse recurso;

- Disponibilidade efetiva para psicoterapia como facilitador para a eventual indicação endocrinológica e cirúrgica.

\subsection{Diagnóstico diferencial}

Esse tópico se configura especialmente importante pois, sendo o diagnóstico de transtorno de identidade de gênero ou mesmo o de 
transexualismo eminentemente clínico, baseado em entrevista, anamnese e acompanhamento subseqüente, faz-se fundamental a diferenciação de outras possibilidades clínicas e psiquiátricas no seguimento clínico desses indivíduos.

O acompanhamento de um transexual é completamente distinto quando comparado ao de um homossexual, travesti ou mesmo de um psicótico. Outro fator a ser considerado é a cirurgia de redesignação sexual, procedimento radical que deve ser indicado unicamente para pacientes que se enquadrem na categoria específica que se beneficiará dela. No caso, os transexuais.

Alguns estudiosos, por meio de pesquisas com essas categorias de pacientes, têm oferecido contribuições significativas para a elaboração dos diagnósticos diferenciais.

MEYER (1974), baseado na avaliação de 67 pacientes masculinos que buscavam a cirurgia de redesignação sexual, afirma que muitos procuravam a cirurgia como forma de superar depressão, ansiedade e psicose "borderline". Outros perseguiam a cirurgia com sentido de atuação sado-masoquista ou de outras perversões. Alguns tentavam escapar do estigma da homossexualidade intolerável.

Além dos fatores motivacionais, muitos indivíduos com sintomas de transtorno de identidade de gênero são descritos como esquizóides, depressivos crônicos, tendo transtorno de personalidade "borderline" e poucos, como psicóticos, oligofrênicos ou criminosos. 
LOTHSTEIN (1979), preocupado com indicação cirúrgica para pacientes idosos, faz estudo com travestis e transexuais com mais de 52 anos de idade. Conclui que para a população transexual a cirurgia pode ser benéfica, apesar das dificuldades decorrentes da idade. Já em relação ao grupo de travestis, a indicação cirúrgica deve ser muito estudada e na quase totalidade dos casos, contra-indicada.

WISE e MEYER (1980), discutindo casos de travestis jovens e idosos, propõem alguns critérios diagnósticos para os travestis que se tornam disfóricos em relação ao gênero:

1. Desejo de cirurgia de redesignação sexual;

2. Evidência de desejo e vontade de longa duração de se transvestir;

3. Uma história de longa duração, que pode, ou não, se estender até o presente, de excitação quando transvestido;

4. Ausência de patologias psicóticas ou maníaco-depressivas;

5. História de longa duração de busca de inclinação sexualmente masculina e ativa e, por outro lado, no passado, em que normalmente permaneceu em contraste marcante com desejos femininos secretos;

6. Exclusão evidente de outras variantes clínicas.

Esses pesquisadores indicam a possibilidade desses indivíduos se enquadrarem em uma síndrome "borderline" e do desejo de cirurgia de redesignação sexual ocorrer em condições de estresse. 
LEVINE e LOTHSTEIN (1981), após um período de três anos utilizando métodos psicométricos e entrevistas clínicas com 51 homens que buscavam a cirurgia de redesignação sexual, encontraram:

1. $78 \%$ dos pacientes possuem patologias de caráter, $47 \%$ como marcante e 31\% como sutil. Os diagnósticos mais comuns são: esquizóide e "borderline"; outros diagnósticos que podem ser incluídos são: narcisista, passivo-dependente, paranóide e obsessivo-compulsivo;

2. $6 \%$ são psicóticos;

3. $8 \%$ dos pacientes têm anormalidades que contrariam as descrições clínicas;

4. $8 \%$ dos pacientes exibem apenas disforia de gênero.

Os mesmos autores afirmam que com disforia de gênero são mais saudáveis que homens com disforia de gênero.

BROWN (1990), ao fazer revisão sobre disforia de gênero, encontra como diagnósticos diferenciais desta categoria:

- $\quad$ transexualismo primário e secundário;

- $\quad$ transvestismo com depressão ou regressão (estresse);

- $\quad$ esquizofrenia com transtorno de gênero;

- homossexualidade com transtorno de ajustamento;

- $\quad$ homossexualidade homofóbica;

- $\quad$ transformistas profissionais;

- $\quad$ transtorno de personalidade "borderline" com questões graves de identidade de gênero; 
- $\quad$ transtorno dismórfico corporal;

- $\quad$ transtorno de identidade de gênero, tipo não transexual;

- $\quad$ transtorno de identidade de gênero atípico;

- $\quad$ adaptação ambígua de identidade de gênero;

- $\quad$ simulação.

MANDERSON e KUMAR (2001) retomam um aspecto importante e sempre presente nas avaliações diagnósticas, o de que uma esquizofrenia pode se manifestar com sintomas de transtorno de identidade de gênero.

A exclusão de patologias que possam se confundir com transtorno de identidade de gênero se faz mais fundamental quando se sabe que não existem critérios precisos de diagnóstico para o quadro e, portanto, o risco de má ou errônea indicação cirúrgica é significativo. O cuidado e a tranquilidade nas avaliações de candidatos à cirurgia ajudam a excluir patologias como esquizofrenia, oligofrenia, transtorno dismórfico corporal, além de impedir lesão física em indivíduos homossexuais ou transformistas.

\subsection{Comorbidade}

Esse tema importante na delimitação e caracterização da alteração e sua relação com outros transtornos psiquiátricos está longe de ser unânime sendo, portanto, área a ser arduamente pesquisada dentro da psiquiatria. 
A correlação entre esquizofrenia e transexualismo secundário é levantada por CALDWELL e KESHAVAN (1991). Afirmam que a relação entre transexualismo e outras doenças psiquiátricas é pouco clara e especificamente quanto à esquizofrenia, tema a ser melhor pesquisado, sugerem três caminhos:

- os dois estados são síndromes distintas que podem ocorrer simultaneamente;

- transexualismo é uma forma de esquizofrenia;

- transexualismo é uma forma não específica de psicopatologia.

Outros autores revelam preocupação com possíveis diagnósticos associados - Transtorno de múltiplas personalidades (MODESTIN, EBNER, 1995) e Transtornos alimentares (BECKER, MESTER, 1996; HEPP, MILOS, 2002) - e que talvez tenham relação com o transtorno de identidade de gênero, contudo, nenhuma evidência maior de associação é relatada em nenhum dos artigos pesquisados.

Em relação aos transtornos de personalidade, BODLUND et al. (1993) relatam que enquanto na população geral existe prevalência de 10\% de transtornos de personalidade, entre os transexuais ela chega à cifra de 26\%. Os transtornos mais encontrados são: paranóide, esquizotípico e "borderline". Segundo os autores, ao contrário do que se acredita, os transexuais masculinos não têm mais traços "borderline" nem mais psicopatologia em geral nem pior prognóstico que os transexuais femininos. E explicam esses resultados encontrados como decorrência das características de desenvolvimento de vida dessas pessoas, como 
conseqüência das reações negativas e discriminatórias da sociedade. Esses dados são compatíveis com os encontrados por COHEN et al. (1997) em uma população transexual adolescente holandesa.

ROBERTO (1983), em artigo ainda atual acerca do diagnóstico e tratamento do transexualismo, afirma que os diagnósticos de transtorno de personalidade histérica, transtorno de personalidade paranóide e de depressão são comuns nessa população.

Em aspectos mais amplos, BROWN et al. (1996) encontram em $26 \%$ da amostra populacional de 188 indivíduos que se transvestiam (transexuais, travestis e transgêneros), depressão, ansiedade, "descontrole nervoso" e abuso de substâncias químicas.

Já COLE et al. (1997), estudando 318 transexuais masculinos e 117 femininos, encontram para ambos os grupos:

- Em eixo I: Depressão como o transtorno mais comum e em seguida, presença de transtorno bipolar e esquizofrenia;

- Em eixo II: Transtorno de personalidade "borderline" como mais freqüente e em segundo lugar o transtorno esquizóide.

Completam afirmando que o grupo de indivíduos com transtorno de identidade de gênero aparenta ser relativamente "normal" em termos de diagnóstico de comorbidade de problemas psiquiátricos. "De fato, a incidência de problemas psiquiátricos reportados é similar à encontrada na população geral” (COLE et al., 1997).

Por fim, CAMPO et al. (2003), relatando pesquisa realizada com psiquiatras holandeses que trabalham com indivíduos com transtorno de 
identidade de gênero, informa que dos 584 pacientes aferidos, 39\% (225) tinham como diagnóstico primário transtorno de identidade de gênero; $61 \%$ (359) tinham comorbidade com outros transtornos psiquiátricos, sendo que em $75 \%$ (270) desses, o transtorno de identidade de gênero era interpretado como sendo secundário a outro transtorno psiquiátrico como: transtorno de personalidade, transtorno de humor, transtorno dissociativo e transtorno psicótico.

Pelos dados apresentados, a seara é ainda confusa e deve ser pesquisada em paralelo à busca de uma objetivação diagnóstica capaz de diferenciar quadros e revelar transtornos de identidade de gênero e suas relações com outras patologias psiquiátricas.

\section{$2.11 \quad$ Tratamento}

Confusões entre os diversos tipos de transtornos de identidade de gênero e o transexualismo podem levar a erros de diagnóstico e, portanto, de indicação de tratamento. Apesar de alguns autores (PURI, SINGH, 1996; MARKS, MATAIX-COLS, 1997; MARKS et al., 2000) relatarem tratamentos eficazes e específicos para casos isolados de transtornos de identidade de gênero, o diagnóstico principal é que deve ser bem formulado e tratado.

PURI e SINGH (1996) decrevem um caso de esquizofrenia que apresentava como sintoma delirante um transtorno de identidade sexual. Tratado com Pimozide, apresentou melhora. 
Já MARKS e MATAIX-COLS (1997) descrevem um caso de transtorno obssessivo-compulsivo com sintomas de transtorno de identidade de gênero que apresentou melhora significativa, quando o transtorno ansioso foi adequadamente tratado. Anos depois, MARKS et al. (2000) descrevem o mesmo caso e acrescentam mais cinco descritos como disforia de gênero que remitiram durante um período prolongado de tempo sem medicação ou psicoterapia. Após esse período de remissão, todos os cinco relatos, naturalmente retomaram os sintomas de disforia de gênero (quatro vivendo parcialmente ou integralmente como mulher e um caso de transexualismo feminino, vivendo como homem).

Outro artigo (DASKALOS, 1998) relata mudança de orientação sexual e não de identidade de gênero em seis transexuais masculinos, ou seja, deixa de lado a preferência por homens, preferindo então mulheres.

BARLOW et al. (1979) relatam três casos de mudança de identidade de gênero, com um seguimento de seis anos e meio. $O$ tratamento proposto foi o de psicoterapia comportamental para os três e em um único caso, associado ao uso de amitriptilina e diazepam.

Em linhas gerais, existe consenso atual - que teve início com os trabalhos pioneiros de Harry Benjamin - entre profissionais que trabalham com pacientes que sofrem de transtorno de identidade de gênero, de que o tratamento para alívio da disforia e resolução das questões relativas à identidade de gênero, especialmente o transexualismo, se baseia em um tripé formado por:

- Psicoterapia; 
- Tratamento hormonal;

- Cirurgia de redesignação sexual.

Esse tripé não é necessariamente seqüencial, muitas vezes um recurso é somado a outro, visando maior eficácia (LEVINE, LOTHSTHEIN, 1981; ROBERTO, 1983; DOLAN, 1987; BROWN, 1990; KOK, 1993; COHEN-KETTENIS, GOOREN, 1999; JURADO et al., 2001).

Outros recursos como, por exemplo, a indicação de hospital-dia, pode ser útil em casos específicos que necessitem de assistência intensa (BABINSKI, REYES, 1994).

Referência fundamental e amplamente disseminada entre os pesquisadores da área são as recomendações existentes em "Os Padrões de Cuidado para Transtorno de Identidade de Gênero" da The Harry Benjamin International Gender Dysphoria Association (HBIGDA), fundada em 1977, cujo comitê apresenta uma seleção feita entre grandes estudiosos do assunto. Atualmente na 6 $6^{\underline{a}}$ versão, publicada em 2001 (as anteriores são de 1979, 1980, 1981, 1990 e 1998), a referência é subdividida em treze capítulos abordando desde epidemiologia, diagnóstico e tratamento para adultos, adolescentes e crianças.

Esses Padrões de Cuidado para Transtornos de Identidade de Gênero da The Harry Benjamin International Gender Dysphoria Association (HBIGDA, 2001) valorizam não apenas o tripé terapêutico (psicoterapia, hormonioterapia e cirurgia) mas também a necessidade do paciente viver integral e realmente como se pertencesse ao gênero desejado antes de 
qualquer medida definitiva, como a cirurgia. A seguir, como cada etapa do tratamento é preconizada pelos padrões de cuidado da HBIGDA.

Em relação à psicoterapia, a HBIGDA avalia que:

- $\quad$ A psicoterapia pode ser extremamente útil para as descobertas e processo de amadurecimento e conforto pessoal;

- $\quad$ Não é requisito absoluto para o tratamento em três etapas. Fica a cargo da avaliação da equipe profissional, a indicação ou não de psicoterapia;

- $\quad$ O estabelecimento de uma relação terapêutica verdadeira e efetiva é o primeiro passo necessário para o sucesso do trabalho da equipe;

- $\quad$ O processo pode ser longo e envolve até o seguimento póscirúrgico. Não necessariamente a psicoterapia vai caminhar para a hormonioterapia e cirurgia. Várias questões podem ser abordadas e deve-se levar em conta o processo todo de transformação e amadurecimento;

- Vários processos de transformação ocorrem espontaneamente durante a psicoterapia. Essa adaptação de gênero deve ser acompanhada e estimulada para melhores condições afetivoemocionais;

- $\quad$ Em termos de ações a serem tomadas pelos pacientes:

- Biologicamente homens: transvestismo; mudança corporal como, por exemplo, a retirada de pelos; aumento do cuidado pessoal, guarda-roupa e voz. 
- Biologicamente mulheres: transvestismo; mudanças corporais tais como usar faixas peitorais, aplicação de pelos faciais teatrais; uso de próteses penianas ou outros recursos similares como enchimentos.

- Para ambos: aprender mais sobre o fenômeno de transgênero, freqüentando grupos de apoio, lendo sobre, grupos de discussão na internet, etc..

- Em termos do processo psicoterapêutico propriamente dito:

- Aceitação das fantasias pessoais, sejam elas homossexuais ou bissexuais e dos comportamentos (orientação), como distintos das aspirações relativas à identidade de gênero e papel de gênero; saber avaliar as necessidades e compromissos familiares e profissionais assumidos; saber integrar as mudanças de gênero no seu dia-a-dia; identificar e incrementar seus pontos destoantes e frágeis na adequação ao gênero pretendido tanto nas relações de trabalho como pessoais.

É importante assinalar que essa é uma visão particularmente norteamericana do que chamam psicoterapia: um recurso voltado para o bemestar imediato e envolto por pragmatismo evidente. Além do quê a aceitação de tais diretrizes propostas pela HBIGDA por entidades e equipes de pesquisa não reflete um esquema específico de trabalho psicoterapêutico, nem mesmo a aceitação de apenas uma linha teórica mas sim, um consenso do que pode e deve ser alcançado pelo paciente e equipe de trabalho. 
Em relação à hormonioterapia em adultos, a HBIGDA (2001) avalia que:

As razões para a hormonioterapia se justificam pelo fato de que o tratamento com hormônios do sexo desejado desempenha importante papel anatômico e psicológico no processo de transição de gênero e na seleção adequada de adultos com transtorno de identidade de gênero. Eles melhoram a qualidade de vida e limitam a comorbidade psiquiátrica pois o paciente passa a se sentir e se parecer com os membros do gênero preferido, além de serem medicamente necessários para se viver nessa nova condição.

Estabelecem ainda três critérios de inclusão para a hormonioterapia:

1. 18 anos de idade;

2. Conhecimento demonstrável dos limites e possibilidades de ação dos hormônios, além de seus riscos e benefícios sociais;

3. Experência de vida no gênero desejado documentada de pelo menos três meses antes do início do tratamento hormonal ou um período de psicoterapia de duração especificada pelos profissionais da equipe de saúde antes da avaliação inicial para a hormonioterapia (geralmente um mínimo de três meses).

Em circunstâncias especiais é aceitável a prescrição de hormônios para pacientes que não preencham o terceiro critério, por exemplo, para 
monitorar terapia com hormônios conhecidos com o intuito de evitar o uso sem supervisão médica ou o mercado negro.

Levantam ainda a possibilidade, em casos especiais e após avaliação de equipe responsável, de se prescrever hormônios a pacientes que não queiram a cirurgia ou que não desejem uma experiência de vida no outro gênero ou mesmo que estejam encarcerados.

Os efeitos desejados e benéficos da hormonioterapia em adultos relatados pela HBIGDA (2001) são:

Para os biologicamente homens tratados com estrógenos: crescimento das mamas, redistribuição da gordura corporal no padrão feminino, diminuição da força no segmento superior corporal, maciez da pele, diminuição dos pelos corporais, diminuição ou parada da queda de cabelos, diminuição do tamanho e da fertilidade testicular, ereções com menor freqüência e com menor firmeza. A grande maioria desses efeitos são reversíveis, com excessão do aumento das mamas. Para as biologicamente mulheres tratadas com testosterona, as seguintes mudanças podem ser consideradas permanentes: voz mais grave, aumento do clitóris, atrofia de mamas, aumento de pelos faciais e corporais no padrão masculino. Mudanças reversíveis são: aumento da força no segmento superior corporal, ganho de peso, aumento do interesse social e sexual, aumento do desejo sexual e diminuição da gordura do quadril. 
Em função dos riscos envolvidos, alguns pacientes devem ser muito bem avaliados clinicamente antes do início de hormonioterapia: fumantes, obesos, idosos, pacientes com doenças cardiovasculares, hipertensos, com doenças endócrinas, com câncer e aqueles com problemas de coagulação.

Os efeitos colaterais descritos pela HBIGDA (2001) são:

- Para os biologicamante homens tratados com estrógenos ou progestógenos: aumento da propensão à coagulação sangüínea, desenvolvimento de prolactinomas benignos, infertilidade, ganho de peso, labilidade emocional, doenças hepáticas, formação de cálculos biliares, sonolência, hipertensão e diabetes melito.

- Para as biologicamente mulheres tratadas com testosterona: infertilidade, acne, labilidade emocional, aumento do desejo sexual, mudança dos perfis lipídicos para o padrão masculino com aumento do risco de doenças cardiovasculares e potencial para desenvolver tumores benignos ou malignos de fígado, além de disfunções nesse órgão.

Os hormônios podem ter suas doses reduzidas após a gonadectomia e o uso de antiandrógenos pode ser considerado tratamento adjuntivo ao uso de estrógenos, em indivíduos biologicamente homens.

Após a psicoterapia e a hormonioterapia, seqüenciais ou não, a avaliação da capacidade do paciente em viver adequadamente no gênero desejado é uma das variáveis mais importantes para a HBIGDA (2001). 
Antes da cirurgia de redesignação sexual, a experiência de viver no gênero desejado é considerada fundamental para a indicação adequada desse procedimento terapêutico. Saber enfrentar as mudanças de vida (profissionais, afetivas, estudantis, sociais e mesmo parentais) são de fundamental importância para a indicação cirúrgica. Avaliar cada situação específica é dever da equipe. Mediar a fantasia e o que se quer, com a realidade, é a tarefa principal da equipe e do paciente antes de aventar e enfrentar essa possibilidade de definição, que é irreversível.

Em relação à cirurgia de redesignação sexual, a HBIGDA (2001) avalia:

- Constitui tratamento efetivo e apropriado para transexualismo ou Transtorno de Identidade de Gênero profundo;

- $\quad$ O cirurgião deve fazer parte da equipe, conhecê-la e confiar em suas opiniões;

- Os critérios de indicação cirúrgica envolvem desde idade mínima (maioridade legal, que varia de país para país), tempo de hormonioterapia e experiência real de vida no gênero desejado até conhecimento de riscos, custos e possíveis complicações;

- O cirurgião deve possuir competência especializada em técnicas de reconstrução genital. Deve ser urologista, ginecologista, cirurgião plástico ou geral, sendo reconhecidamente hábil e suficientemente treinado para as tarefas a serem realizadas. 
As cirurgias indicadas são:

Cirurgia de mamas: retirada de mamas para transexuais femininos ou aumento dessas ou colocação de próteses para transexuais masculinos;

- Cirurgia genital: para transexuais masculinos: orquiectomia, penectomia, vaginoplastia, clitoroplastia e labiaplastia. A manutenção, sempre que possível, da enervação no tecido usado na construção da neovagina é fundamental na recuperação cirúrgica e na funcionalidade do órgão. Para transexuais femininos: histerectomia, salpingo-oforectomia, vaginectomia, metoidioplastia, escrotoplastia, uretroplastia, colocação de próteses testiculares e faloplastia;

Outras cirurgias indicadas: para transexuais masculinos: redução plástica da cartilagem tireóide, lipoaspiração da cintura e do quadril, rinoplastia, redução dos ossos da face e blefaroplastia. Para transexuais femininos: lipoaspiração nos quadris, coxas e nádegas.

Além de todas essas medidas indicadas, a HBIGDA (2001) recomenda um seguimento cirúrgico, psicoterápico e hormonal a curto e longo prazo.

A partir desses padrões estabelecidos pela experiência adquirida em anos de trabalho, pesquisa e estudos, o atendimento da população que sofre de transtornos de identidade de gênero estandardizou-se, mas 
respeitando sempre as particularidades de cada país, sua legislação e cultura.

Contudo, vários autores, além dos que participam da HBIGDA, pesquisam e publicam artigos sobre o tripé terapêutico, contribuindo e enriquecendo essa área de estudo. A seguir, para cada tópico, vêem-se alguns deles.

\section{PSICOTERAPIA}

WISE e LUCAS (1981) descrevem caso interessante do que chamam de pseudotransexualismo (disforia de gênero iatrogênica). Nesse artigo é relatada a história de uma mulher homossexual que tinha fantasias de engravidar sua psicoterapeuta. Quando esta realmente engravida, a paciente inicia um processo de estigmatização de sua própria homossexualidade e aumenta seu desejo de se tornar homem. $O$ impasse atinge seu máximo na separação que acontece para o parto, quando a paciente busca efetivamente serviços para realizar a cirurgia. Um ponto importante levantado pelos autores seria a questão da transferência e do vínculo terapêutico, ambos colocados em cheque pelos acontecimentos.

Uma série de trabalhos clássicos sobre psicoterapia com pacientes com transtorno de identidade de gênero (LOTHSTEIN, 1979; LEVINE, LOTHSTEIN, 1981; KELLER et al., 1982; STERMAC et al., 1991) valorizam a psicoterapia grupal e não apenas a individual.

KELLER et al. (1982) afirmam: 
a psicoterapia grupal provou ser o modelo ideal para tratamento, observação e avaliação de pacientes com disforia de gênero antes, durante e após a cirurgia de redesignação sexual.

Essa mesma conclusão é compartilhada por STERMAC et al. (1991).

Já LEVINE e LOTHSTEIN (1981), além de valorizarem a psicoterapia grupal, enfatizam a importância da aliança terapêutica e da associação entre psicoterapia e cirurgia de redesignação sexual. Afirmam que cerca de $70 \%$ dos pacientes com disforia de gênero e em psicoterapia acabam optando por soluções não-cirúrgicas.

Os psicólogos MIDENCE e HARGREAVES (1997) em artigo de revisão, afirmam que o ajustamento psicossocial de transexuais masculinos deve ser melhor pesquisado. Elogiam os trabalhos de Lothstein, mas criticam a qualidade dos outros trabalhos publicados.

Por fim, YÜKSEL et al. (2000) relatam a experiência na Turquia do trabalho com transexuais, especificamente femininos. Naquele país, a cirurgia de redesignação sexual apenas pôde ser legalmente feita a partir de maio de 1988. Desde então, qualquer médico, desde que o paciente se mostre interessado, pode realizar esse tipo de cirurgia sem necessidade de laudo psiquiátrico ou preparação psicológica pré- ou pós-cirúrgica. A lei turca permite ainda a mudança da certidão de nascimento e o casamento desses indivíduos. Para os transexuais masculinos as questões estão bem melhor estabelecidas, porém o mesmo não acontece com a população feminina. 
Nesse artigo, os autores descrevem a experência com um grupo de transexuais femininos, a alta coesão grupal e a importância desse trabalho psicoterapêutico.

\section{HORMONIOTERAPIA}

As propostas terapêuticas hormonais são todas muito semelhantes e seguem as mesmas linhas diretrizes da HBIGDA (2001).

Esquematicamente (Tabela 5), pode-se reproduzir o papel do endocrinologista dentro da equipe de tratamento interdisciplinar do transexualismo da seguinte forma, segundo MICHEL et al. (2001): 
Tabela 5 - Papel do endocrinologista no tratamento de transexuais

\begin{tabular}{lll}
\hline $\begin{array}{l}\text { FASE DE } \\
\text { REDESIGNAÇÃO }\end{array}$ & $\begin{array}{l}\text { PAPEL DO METODOLOGIA } \\
\text { ENDOCRINOLOGISTA }\end{array}$ \\
\hline Pré-inclusão & $\begin{array}{l}\text { Confirma a ausência de } \\
\text { doenças endócrinas } \\
\text { (interssexualidade) }\end{array}$ & $\begin{array}{l}\text { Anamnece e avaliação } \\
\text { clínica }\end{array}$ \\
& $\begin{array}{l}\text { Controla a falta de } \\
\text { contraindicação para } \\
\text { posterior hormonioterapia }\end{array}$ & $\begin{array}{l}\text { Cariótipo, "check-up" } \\
\text { endócrino e biológico; } \\
\text { teste neuroendócrino } \\
\text { dinâmico. }\end{array}$ \\
\hline
\end{tabular}

Pré-cirúrgica (pré-castração)

Ausência de efeitos
colaterais clínicos e
biológicos indesejáveis

Anamnese e avaliação clínica; testes endocrinológicos e biológicos basais a cada 3-6 meses.
Pós-cirúrgico (pós castração) (terapia substitutiva)
Ausência de efeitos colaterais indesejáveis; controle de um bom equilíbrio "fisiológico"
Anamnese e avaliação clínica; testes endocrinológicos e biológicos (+ PSA?); testes dinâmicos se orbigatório (TRH, TTGO); densitometria óssea a cada $1-2$ anos.

PSA: teste de antígeno prostático específico

TRH: teste do hormônio de liberação de tireotrofina TTGO: teste de tolerância à glicose oral

O acompanhamento e controle favorecem o trabalho de toda a equipe, incluindo aí o do psiquiatra, psicólogo e mesmo o do cirurgião.

Cabe ressaltar que existem condições clínicas e não apenas psíquicas que contra-indicam a hormonioterapia. Contra-indicações absolutas só existem para transexuais masculinos: hipertensão diastólica grave, doenças tromboembólicas ou tromboflebite, doença cerebrovascular e 
disfunção hepática grave. Contra-indicações relativas para transexuais masculinos são: tabagismo severo, história familiar de câncer de mama, hiperprolactinemia e obesidade severa. Em relação ao transexuais femininos, há apenas contra-indicações relativas: diabetes pré-existente, hipertrigliceridemia e/ou hipercolesterolemia e obesidade severa (MICHEL et al., 2001).

Vale relembrar que os efeitos desejados e indesejados são os mesmos que a HBIGDA (2001) relata.

Quanto ao uso de medicamentos, podem ser utilizados estrógenos e progestagênios para os transexuais masculinos. No Brasil e em alguns outros países pode ser usado o acetato de Ciproterona, substância antiandrogênica, que não é aprovada para uso pelo Food and Drug Administration (FDA) dos EUA. O uso de espironolactona e/ou agonistas de GnRH (hormônio liberador de gonadotrofina) também pode ser associado para minimizar as doses de estrógeno necessárias para a feminização (COLUCCIELO, 1996; JURADO et al., 2001; MOORE et al., 2003).

Para os transexuais femininos, hormônios androgênicos tipo testosterona são os mais utilizados e em variadas preparações (COLUCCIELO, 1996; JURADO et al., 2001; MOORE et al., 2003).

Os resultados do uso de hormônios em transexuais são espetaculares e contribuem para que possam iniciar a vida em seu gênero de escolha. A transformação fenotípica causada nos transexuais masculinos depende muito da idade de início de uso de estrógenos, antiandrogênios ou progestagênios. Quanto mais cedo o uso desses hormônios ou medicações 
em transexuais masculinos, melhor. Ou seja, se o uso é feito no início da adolescência, mais feminino será o indivíduo. O resultado fenotípico é o de menor ação androgênica, portanto, de menor determinação dos caracteres sexuais secundários masculinos, os quais, uma vez estabelecidos são difíceis de modificar. Se o uso se faz com idade mais avançada, os resultados fenotípicos são menores; mesmo assim, importantes.

No caso dos transexuais femininos, o resultado do uso de andrógenos é fabuloso. A mudança fenotípica é intensa, de mulheres tornam-se rapazes com aceitação social de seu gênero sem grandes questionamentos, o que nem sempre ocorre com os transexuais masculinos. É muito comum se ouvir comentários em voz baixa a seu respeito: "É mulher ou homem?", "É mulher ou travesti?", coisa que não costuma ocorrer com os transexuais femininos que tomam andrógenos.

\section{CIRURGIA}

Os princípios que regem as cirurgias de redesignação sexual já foram explanados anteriormente. A necessidade de um diagnóstico preciso e a preparação do paciente, seja transexual masculino ou feminino, é fundamental para o sucesso cirúrgico e de satisfação do paciente.

A integração entre o cirurgião e os demais profissionais da equipe (psiquiatra, psicólogo e endocrinologista) é fundamental, bem como a participação da enfermagem que deve estar preparada e treinada para lidar com essa população, o serviço social e outras áreas como, por exemplo, a 
fonoaudiologia, otorrinolaringologia e outros que se façam presentes ao longo processo que envolve o tratamento dos transexuais.

Todas as cirurgias possíveis para a população transexual são aquelas descritas pela HBIGDA (2001) já relatadas.

As genitais são de exterma importância e valia, tanto pelo significado evidente da concretude da identidade de gênero buscada e adquirida quanto pela nova configuração corporal estabelecida, em que até mesmo $\mathrm{o}$ ato de andar tem que se transformar e adequar à nova realidade genital.

Para os transexuais masculinos a construção de uma neovagina não só é realizável como existem várias técnicas, todas satisfatórias. ELDH (1993), RUBIN (1993), HUANG (1995), HAGE et al. (1994), KARIM et al., (1996) e JURADO et al., (2001) relatam as técnicas possíveis a serem utilizadas:

Enxertos de pele de áreas extragenitais: realizado e idealizado por ABBE (1898) para agenesia vaginal feminina e utilizado em transexualismo em 1931. Excluem-se os enxertos epidérmicos, sujeitos a retrações. Realizada em único ato operatório, libera a pele penoescrotal e glande para a construção detalhada da estética vulvar. Deixa cicatrizes nas áreas doadoras e exige uma imobilidade prolongada no leito e o uso por seis meses de moldes dilatadores; 
- Enxertos de pele total do pênis: técnica simples, mas limitada às dimensões penianas. Descrita por FOGHANDERSEN (1956);

Retalhos de alças intestinais: utilizada desde 1907 (BALDWIN) e a partir de 1974 (MARKLAND, HASTINGS) realizada em transexuais. O segmento sigmóide é o preferido, porém qualquer outro pode ser utilizado. Evita-se o formato circular do tecido para evitar estenose. Existem vários fatores limitantes ao método, desde a internação prolongada até riscos de anastomoses digestivas e maior vulnerabilidade a doenças sexualmente transmissíveis. Resulta em neovagina de ótimo comprimento, mas com perene secreção de muco;

Retalho cutâneo ou musculocutâneo extragenital: indicada em casos de correção de insucessos de cirurgia anterior. Podem ser utilizados retalhos cutâneos de várias regiões como coxa, área inguinal ou reto abdominal. Dispensa uso de moldes, há menor risco de contração e é utilizada desde 1980 (CAIRNS, DE VILLIERS);

Retalho penoescrotal "ao acaso": recebe essa denominação pela inexistência de pedículo vascular que o percorra. A utilização do tegumento peniano como um tubo invertido foi primeiramente realizada em transexuais por GILLIES e MILLARD JR (1957). O pedículo tanto pode estar na região puboabdominal quanto no períneo. A estética vulvar resultante 
é considerada excelente, mas a neovagina pode ter dimensões reduzidas por necroses avasculares por tamponamento vaginal muito compressivo. Outros resultados indesejáveis são o crescimento de pelos intravaginais pelo uso de pele hirsuta do escroto e perda de sensibilidade na neovagina pela nãopreservação dos nervos dorsais do pênis e da glande.

Retalho tubular vasculonervoso ilhado da pele peniana: utilizada por JURADO (1989) desde 1984 em todos seus casos, exige curta internação. Realizada a um só tempo, pode necessitar revisão após três meses. Toda pele peniana é evertida. Mantêm-se os vasos e nervos dorsais do pênis que percorrem a túnica albugínea. Um tamponamento leve, semicompressivo é necessário, mas por tempo curto, quatro a seis dias. Os resultados costumam ser ótimos.

Em relação aos transexuais femininos, desde que MALTZ (1946) idealizou uma técnica de reconstrução de pênis e uretra, a construção plástica e estética de um períneo masculino e a de um neofalo envolve recursos especiais, muitas vezes pouco funcionais. VESELÝ, HAAGE (1999) e JURADO et al. (2001) informam quais são essas técnicas, etapas, recursos e seus riscos:

Uso de retalhos cutâneos para construção de um tubo/haste para o neofalo: retalhos miocutâneos de várias regiões anatômicas podem ser utilizadas. SNYDER, BROWNE Jr (1977) e HESTER et al. (1984) fazem referência ao uso de 
retalho infraumbilical. PUCKETT e MONTIE (1978), ao de retalho inguinal. MORALES et al. (1956), retalho femoral. ORTICOCHEA (1972), retalhos musculocutâneos do grácil. SANTI et al. (1988) preferem utilizar retalho do músculo reto abdominal. Já a reconstrução por microcirurgia é limitada. O "retalho chinês", idealizado por CHANG, HWANG (1984), utiliza parte do osso radial. Todos podem deixar seqüelas nas áreas doadoras, além do resultado final ser pouco satisfatório pois os tubos de retalho de pele apresentam morfologia inadequada para um neopênis como cor, presença de pêlos, ausência de glande e outros.

Metoidioplastia: implica alargamento e prolongamento do clitóris. Após tratamento androgênico, ocorre certa hipertrofia do clitóris e essa pode ainda ser um pouco aumentada com uso de tecido adiposo ou silicone. A uretra é também transposta. O benefício é a manutenção da irrigação e sensibilidade. DURFEE e ROWLAND (1973) foram os primeiros a descrever esse tipo de cirurgia em transexuais.

A transposição da uretra, apesar das dificuldades técnicas, é desafio menor que conseguir uma ereção fisiológica e a construção de uma glande anatomicamente satisfatória. Já a bolsa escrotal e testículos são facilmente reproduzidos por meio da sutura dos lábios vaginais e colocação de próteses testiculares (JURADO et al., 2001). 
Outras cirurgias envolvendo a transformação de um transexual masculino são: aumento de mamas com ou sem colocação de próteses; retirada cirúrgica da cartilagem tireóide; correções estéticas como nariz, ossos da face. Para os transexuais femininos, outras cirurgias envolvidas são: mastectomia; histerectomia; ovariectomia; cirurgias plásticas e para correção de voz, se necessário (MONSTREY et al., 2001).

Em conclusão, COHEN-KETTENIS, WALINDER (1987), HAGE (1995) e MONSTREY et al. (2001) reconhecem todas as cirurgias envolvidas no processo de redesignação sexual como método terapêutico e resolutivo para transexualismo ou transtornos de identidade de gênero graves. Ressaltam a importância do trabalho em equipe, especialmente o papel do psiquiatra, do psicólogo e do endocrinologista, sem se desfazer dos outros profissionais. Ressaltam ainda os riscos e complicações de cada cirurgia ou etapa cirúrgica, os quais apesar de serem muitos e possivelmente graves, não contraindicam a realização.

A cirurgia de redesignação sexual, apesar de crucial, não estabelece o fim do tratamento. Ela concretiza o desejo, realiza o sonho. Contudo, é apenas a anatomia corrigida. A satisfação é verdadeira, mas pode se revelar parcial. O acompanhamento pós-cirúrgico é fundamental e estabelece a continuidade do tratamento, permitindo abordar questões importantes como: “A realização pessoal se deu?”, "Como será a aceitação social?", "O que mais precisa ser visto, transformado e refeito?", "Como será sua realização afetiva, sexual e familiar?". 
A cirurgia coroa uma busca vital, mas não resolve nem muda tudo. Conforme vê-se a seguir.

\subsection{Seguimento pós-cirúrgico}

Questões como estabilidade emocional, grau de satisfação e qualidade de vida são as que podem evidenciar, como adequados e efetivos os tratamentos aceitos e propostos para os transtornos de identidade de gênero.

Desde o início das cirurgias de redesignação sexual a preocupação com a eficácia do tratamento e suas conseqüências estão presentes em estudos. O medo da lesão irreversível e mal indicada, a moral arraigada e presente nas atitudes e pensamentos médicos desde a década de 50 do século $X X$, se não impedem a realização das cirurgias, pelo menos promovem um cuidado em suas indicações e na avaliação de suas conseqüências.

As opiniões conflitantes de variados estudos sobre a cirurgia de mudança sexual resultaram em um primeiro estudo que incluiu um grupo transexual de controle que não recebeu a cirurgia de redesignação sexual. Os resultados foram considerados negativos em relação à cirurgia e concluíram que a cirurgia de redesignação sexual não mostrava vantagem alguma em termos de reabilitação social e satisfação dos pacientes (MEYER, RETER, 1979). 
Como conseqüência, em 1980 é extinto o programa de mudança sexual da Clínica de Identidade de Gênero da John Hopkins University School of Medicine nos Estados Unidos da América do Norte. Estudos subseqüentes relacionam o resultado negativo dessa pesquisa a fatores psiquiátricos não identificados nos pacientes, que acabaram influenciando as conclusões alcançadas (THOMAS, 1993), o que nos traz novamente a importante questão da precisão diagnóstica para essa população.

Estudo realizado por LIEF e HUBSCHMAN (1993) com transexuais masculinos ( $n=14)$ e femininos $(n=9)$ após a cirurgia de redesignação sexual, revela que a capacidade orgásmica cai entre os transexuais masculinos e se eleva nos femininos. Apesar do decréscimo de orgasmos entre os transexuais masculinos, a satisfação sexual e em geral com os resultados da cirurgia é alta nos dois grupos. A satisfação geral, de $86 \%$, é similar a de outros estudos (GREEN, FLEMING, 1990). A freqüência de atividade sexual aumentou em cerca de $75 \%$ entre os transexuais masculinos e em cerca de $100 \%$ entre os femininos. A faloplastia não parece ser fator crítico no orgasmo e na satisfação sexual dos transexuais femininos. Por fim, concluem que a mudança corporal e de identidade sexual produzem satisfação que compensa a atividade sexual não-funcional.

Alguns autores (COHEN-KETTENIS, VAN GOOZEN, 1997; SMITH et al. 2002), estudando transexuais masculinos adolescentes após a cirurgia de redesignação sexual, chegam à conclusão de que a disforia diminui consideravelmente e que o funcionamento psíquico e social são adequados 
após a cirurgia. A utilização do teste de Rorschach confirma as afirmações de estabilização psíquica e social após a cirurgia.

Para os transexuais masculinos, vários autores (BLANCHARD et al., 1989; SNAITH, TARSH, REID, 1993; TSOI, 1993; RAKIC et al., 1996; REHMAN et al., 1999), em vários países (Canadá, Holanda, Cingapura, lugoslávia, Estados Unidos da América do Norte), revelam alto grau de satisfação após a cirurgia. Seja em relação anatômica ou estética, seja social, relacional, afetiva, ou mesmo na adoção de crianças. Um pequeno número se mostra insatisfeito (cerca de 10\%), mas geralmente ligado a uma má preparação para a cirurgia, ou mesmo questões de erro diagnóstico.

Em relação aos transexuais femininos, McCAULEY, EHRHARDT, (1984) demonstram em um grupo acompanhado por até nove anos após a avaliação inicial que, em seguida a uma triagem diagnóstica bem feita, um processo psicoterapêutico efetivo e cirurgias feitas com sucesso, o índice de satisfação apresentado é alto e se materializa em relacionamento estável, emprego e adoção. Contudo, relembram sempre da necessidade de avaliação psicoterapêutica pós-cirúrgica e da precisão diagnóstica.

Outros pesquisadores (COLEMAN et al., 1993), ao estudar uma população de transexuais femininos pós-cirúrgica na qual nenhum membro fez faloplastia e todos eram bissexuais ou homossexuais (ou seja, tinham desejo por homens homossexuais), encontram alto grau de satisfação sexual, mesmo em relações com penetração (sendo ativo ou passivo) e alto grau de inclusão social e afetiva. 


\subsection{Outras questões relevantes}

Alguns outros pontos importantes relacionados aos transtornos de identidade de gênero merecem destaque. De certa maneira, estão ligados ao transtorno e influenciam, especialmente em relação ao transexualismo, a qualidade de vida e o sentido de realização desses indivíduos.

As atitudes das pessoas em relação ao transexualismo é um aspecto importante, tendo sido analisado de maneira complexa por LANDÉN e INNALA (2000) em amplo estudo realizado na Suécia. Os resultados obtidos podem ser assim resumidos:

- a grande maioria aceita a possibilidade dos transexuais poderem ter seu sexo redesignado;

- $\quad 63 \%$ acreditam que a própria pessoa deva pagar por isso e não o Estado;

- a grande maioria acredita que eles possam se casar e trabalhar com crianças após a mudança;

- $\quad 43 \%$ apóiam a adoção de crianças por transexuais operados e $41 \%$ são contra;

- $\quad$ homens e o grupo com idade mais alta apresentam visão mais restritiva, que os grupos de mulheres e os de idade mais jovem.

Outra questão que desperta interesse científico é a dos parceiros. Quem são essas pessoas que se interessam e têm desejo por transexuais, 
ou, em sentido mais amplo, por quem sofre de transtorno de identidade de gênero?

BLANCHARD e COLLINS (1993) realizam estudo a respeito de homens que se interessam por travestis, transexuais e homens feminilizados. Dão a esse desejo o nome de ginandromorfofilia. Afirmam que essa população é muito maior do que se imagina em função do mercado voltado para eles: publicações, revistas pornográficas, prostituição específica em ruas e em anúncios publicados em jornais diários.

Encontram três padrões de comportamento.

1. primeiro grupo, ou padrão comportamental, refere-se a homens que buscam essa população com fins românticos, de se relacionar afetivamente com eles. Não se transvestem e não fazem diferenciação de termos entre transexuais, travestis ou qualquer outro tipo; são masculinos e vivem como tal.

2. segundo grupo é aquele que se reconhece como com atividades de travestis, seja ao se vestir, seja no estilo de vida. Procuram outros para encontros sexuais ou ligações afetivas.

3. terceiro e último grupo, residual, é aquele em que se encaixam os travestis e transexuais, que não buscam alguém parecido com eles mas, sim, homens masculinos, de preferência, hipermasculinos.

Os pesquisadores ressaltam que nenhum dos integrantes das três categorias se definiu como "gay" ou homossexual. Apenas poucos se 
definiram como bissexuais. A grande maioria não fez referência ao seu estado civil, poucos assumiram que eram casados.

As conclusões finais são de que a grande maioria desses homens não é composta de pessoas com atividades ou comportamentos transvésticos. Os ginandromorfófilos "puros" se diferenciam dos travestis "puros" por vários motivos, desde a forma como se reconhecem, esperam ser tratados (como homem ou mulher) até pela preferência de papel dominante na interação sexual. Para esses estudiosos, todas essas evidências constituem a base para a afirmação de que a ginandromorfofilia se constitui como interesse erótico separado e particular.

As expressões "maioria" e "poucos" encontradas no parágrafo anterior são do texto pesquisado. Os autores não fazem referência à porcentagem ou números absolutos e optam pelo uso desses termos.

Já entre transexuais femininos, STEINER e BERNSTEIN (1981) direcionam a pesquisa mais para as características da relação estabelecida do que meramente do parceiro. Encontram, em relação às parceiras, que:

- $\quad 95 \%$ tiveram previamente coito com parceiros homens;

- $10 \%$ tiveram relações homossexuais ( com mulheres), enquanto $90 \%$ negam esse tipo de relação;

- $\quad 73 \%$ relatam orgasmo com homem, $27 \%$ negam;

- $\quad 100 \%$ relatam orgasmo no sexo com parceiro transexual;

- $\quad 95 \%$ se vê como mulher durante a relação sexual, $5 \%$ como homem e como mulher em tempos alternados; 
- $\quad 91 \%$ reconhece seu parceiro como homem durante fantasias sexuais, $9 \%$ o vê nos dois papéis (masculino e feminino).

- Em relação aos transexuais:

- $\quad 100 \%$ preferem parceiras mulheres;

- $\quad 41 \%$ já tiveram intercurso sexual com homens;

- $\quad 85 \%$ já tinham tido relação sexual com mulheres;

- $\quad 23 \%$ revelam orgasmo durante a atividade sexual com homens;

- $\quad$ apenas $85 \%$ dizem ter orgasmo durante intercurso sexual com mulheres;

- $\quad 100 \%$ quer ter um pênis;

- $\quad 100 \%$ se vê como homem durante o sexo e vê a parceira como mulher.

Concluem afirmando que os transexuais querem exercer o papel de pai e muitas vezes escolhem parceiras que já tenham filhos; além disso, as companheiras contribuem para sua estabilidade na fase de transformação. Já as parceiras relatam casamentos infelizes prévios e vêem a atual relação com esse "homem sem pênis" como segura, sem riscos de gravidez e estável. O somatório dessas buscas faz desse tipo de relacionamento um espaço sexual e emocionalmente gratificante, o que favorece que a parceria dure muitos anos.

As questões legais envolvendo os transexuais também formam tópico importante e que determina inclusão social e afetiva após a cirurgia.

RENDLEMAN (1998) expressa a dificuldade da equipe médica em lidar com transexuais pré-cirúrgicos que utilizam nome fictício. 
ALTHOF (1980) analisa a importância da mudança de nome para essa população e as dificuldades encontradas.

No Brasil, ARAUJO (2000) trata em termos jurídicos dos direitos constitucionais que um transexual se faz merecedor após a cirurgia de redesignação sexual. Atualmente, muitos pacientes têm conseguido a mudança de nome e sexo em registro civil (certidão de nascimento), mas ainda na dependência de decisão judicial favorável. A resolução do Conselho Federal de Medicina contribuiu muito para essa mudança jurídica nos ultimos anos.

Em outros países, os problemas não se atêm à questão do nome. Em muitos lugares existe a discriminação legal (COSTA-SANTOS, MADEIRA, 1996; GROMB et al., 1997) e até perseguição policial (YUZGUN, 1993).

Por fim, relacionada às questões legais, existe, pelo menos nos EUA, preocupação com o acesso e as necessidades específicas dessa população no tocante à saúde pública.

LEE (2000), CLARK et al. (2001), GREEN (2000), LOMBARDI (2001) e MEYER (2001) discutem, avaliam e propõem a urgência de um programa de saúde voltado para a população GLBT ("gays”, lésbicas, bissexuais e transgêneros) em que sejam discutidas questões relevantes de cidadania e saúde específicas para eles.

Já WIESSING et al. (1999) e CLEMENTS-NOLLE et al. (2001) discutem a necessidade de um programa específico em relação à AIDS, infecção por HIV e uso de silicone para a população transexual. 
Em relação à mídia escrita, o tema, além de importante e vendável, desperta a curiosidade das pessoas, servindo como meio de dissolução de preconceitos e ignorância, mas também oferecendo a questão como algo sensacionalista. Nos EUA, a revista GQ, na edição de agosto de 2001, publica matéria interessante sobre uma jornalista vivendo como homem (My Life as a Man). A mesma revista, em maio de 2002, revela a história de um professor de inglês, casado e transexual (From a Man to a Woman).

No Brasil são comuns matérias sensacionalistas ou pornográficas. Contudo, a revista "Época", na edição de número 236 de novembro de 2002, publica reportagem esclarecedora sobre o assunto, além de na edição número 295 de 12 de janeiro de 2004 tornar público o trabalho da pesquisadora da Universidade de Stanford, Joan Roughgarden, transexual masculina, operada, que "afirma que os comportamentos homossexual e transexual são abundantes em várias espécies de vertebrados".

O jornal "Folha de São Paulo", nas edições de 14 e 15 de novembro de 2003, publica importante informação e comentário sobre a participação de transexuais na Olimpíadas de Atenas em 2004. Nas edições de 5 e 6 de março de 2004, noticia a presença da transexual masculina operada, Mianne Bagger, competindo no torneio de tênis Aberto da Austrália.

A maior visibilidade dos transexuais pode contribuir para a diminuição do preconceito e da discriminação, o cuidado deve centrar no sensacionalismo e na exploração sexual e pornográfica do tema.

Os transexuais estarão expostos à discriminação, chacota e humilhação alimentadas pela ignorância e preconceito, enquanto não for 
adotada uma postura de legalização, legitimização, reconhecimento e repeito. Cabe também aos profissionais de saúde fomentar e defender essa mudança de atitude e cuidado em relação a esses indivíduos que buscam na Medicina ajuda para resolução de seus problemas.

Em verdade, essa é uma história que está longe do término. A questão transexual é recente dentro da Medicina e mesmo de outras áreas de pesquisa. Só nos últimos 40 anos é que algum conhecimento se estruturou, há muito para ser discutido, revelado, conhecido, e em trabalho integrado.

Esse tema e essa população necessitam de diversas equipes calcadas em princípios sólidos de respeito e atenção à saúde e à cidadania. As questões legais não são específicas desse processo médico, mas a interligação é evidente e necessária, e o distanciamento representaria uma fuga de responsabilidades éticas e sociais.

Tudo isso encontra respaldo na bibliografia pesquisada e adquire caráter de urgência na realidade cotidiana dos transexuais e também daqueles que se dispõem a trabalhar com eles. 
3 OBJETIVOS 


\section{OBJETIVOS}

O objetivo geral desse estudo foi avaliar psicopatologicamente transexuais masculinos e femininos e comparar a evolução e mudanças no quadro psicopatológico desses pacientes após dois anos em psicoterapia de grupo.

Os objetivos específicos foram:

1. Avaliar a presença de transtornos do eixo I e de personalidade em transexuais masculinos e femininos;

2. Comparar presença ou não de Depressão e Transtornos de Personalidade em transexuais masculinos e femininos antes e após dois anos de psicoterapia grupal;

3. Pesquisar características demográficas dos integrantes do grupo de transexuais masculinos e femininos;

4. Comparar características demográficas gerais e entre os integrantes dos grupos de transexuais masculinos e femininos;

5. Estruturar um temário modelo para um processo de psicoterapia de grupo tematizada para transexuais com, no mínimo, dois anos de duração. 
4 CASUÍSTICA E MÉTODO 


\section{CASUÍSTICA E MÉTODO}

\subsection{Cálculo do tamanho da amostra}

Para o estabelecimento do tamanho da amostra necessária ao estudo, utilizaram-se sete pacientes transexuais que já haviam se submetido a todas as etapas da pesquisa, vista a necessidade de padronização. Desses, seis eram transexuais masculinos. Na avaliação inicial, dois pacientes preencheram critérios diagnósticos para ao menos um transtorno de personalidade e seis apresentavam traços de ao menos um transtorno.

O transtorno evitador de personalidade foi o mais encontrado entre os pacientes (um paciente preenchia critérios diagnósticos e outros três apresentavam traços). Um paciente recebeu o diagnóstico de transtorno misto de personalidade pois preenchia simultaneamente critérios diagnósticos para os transtornos histriônico, dependente, passivo-agressivo e evitador.

$\mathrm{Na}$ avaliação realizada após dois anos de tratamento psicoterápico grupal, nenhum paciente preenchia critérios para o diagnóstico de transtornos de personalidade. Apenas três pacientes apresentavam traços de algum transtorno (dois deles apresentavam traços do transtorno evitador de personalidade).

As avaliações dos sintomas depressivos através do Inventário de Depressão de Beck (BDI) antes e após dois anos de acompanhamento são 
apresentadas na Tabela 6. Três pacientes não apresentaram alterações na pontuação observada na aplicação do BDI antes e após o acompanhamento e outros quatro apresentaram escores menores na segunda avaliação.

A média de pontuação no BDI aplicado no início do estudo foi de 6,1 (desvio-padrão $=5,7$ ) e após dois anos de acompanhamento foi de 3,4 (desvio-padrão = 2,0). A média da variação na pontuação do BDI foi de $-2,7$ (desvio-padrão $=3,9$ ). Excluindo o paciente 1 (que apresentou pontuações muito altas), a média da variação do $B D I$ foi $-1,3$ (desvio-padrão = 1,6).

Tabela 6 - Resultados da pontuação observada no BDI aplicado no início do estudo e após dois anos de psicoterapia grupal $-n=7$

\begin{tabular}{ccccc}
\hline PACIENTE & TRANSEXUAL & $\begin{array}{c}\text { BDI } \\
\text { (inicial) }\end{array}$ & $\begin{array}{c}\text { BDI } \\
\text { (final) }\end{array}$ & $\begin{array}{c}\text { BDI - VARIAÇÃo } \\
\text { (final - inicial) }\end{array}$ \\
\hline $\mathbf{1}$ & $\mathrm{F}$ & 18 & 7 & -11 \\
$\mathbf{2}$ & $\mathrm{M}$ & 8 & 4 & -4 \\
$\mathbf{3}$ & $\mathrm{M}$ & 6 & 4 & -2 \\
$\mathbf{4}$ & $\mathrm{M}$ & 4 & 4 & 0 \\
$\mathbf{5}$ & $\mathrm{M}$ & 1 & 1 & 0 \\
$\mathbf{6}$ & $\mathrm{M}$ & 4 & 2 & -2 \\
$\mathbf{7}$ & $\mathrm{M}$ & 2 & 2 & 0 \\
\hline
\end{tabular}

\subsubsection{Metodologia do cálculo do tamanho da amostra}

A medida da pontuação obtida no BDI foi escolhida como base para os cálculos de tamanho de amostra. Foi definida como variável-desfecho a 
diferença entre o valor do BDI obtido no início do estudo e após o acompanhamento de dois anos em atendimento psicoterápico grupal.

Para o cálculo do tamanho de amostra foi adotada a hipótese nula $\left(\mathrm{H}_{0}\right)$ de que a média da diferença entre a pontuação do BDI antes e após a realização do tratamento psicoterápico seria igual a zero $(B D I$ pós $-B D I 5$ pré $=$ 0), ou seja, a realização da psicoterapia não alteraria o valor do BDI (os sintomas depressivos). A hipótese alternativa $\left(H_{1}\right)$ adotada foi de que a média da diferença entre o valor do BDI antes e após a realização da psicoterapia seria diferente de zero (BDI pós - BDI 5 pré $\neq 0$ ), ou seja, a psicoterapia grupal alteraria o valor do BDI (alteraria o quadro depressivo).

Foi adotado o poder de estudo $=0,8$ (valor mínimo do poder do teste para garantir a validade do estudo). O poder do estudo é definido como a probabilidade de não se cometer erro tipo II. O erro tipo II ( $\beta$ ) corresponde à probabilidade de aceitar $\mathrm{H}_{0}$ quando ela é falsa (aceitar que a psicoterapia não altera os escores do BDI quando, na verdade, altera). Alternativamente, o poder do estudo pode ser definido como a probabilidade de se obter resultados com significância estatística (em geral, 0,05) (BERQUÓ et al., 1981; KIRKWOOD, 1988).

Adotou-se nível de significância do teste $(\alpha)=0,05$ (que corresponde ao erro tipo I do teste, ou seja, à probabilidade de que $\mathrm{H}_{0}$ seja rejeitada quando for verdadeira, o que significa aceitar que a psicoterapia altera os escores obtidos no BDI quando na verdade não há alteração). Como parâmetros da média das diferenças e do desvio-padrão esperados foram utilizados os resultados obtidos até o momento realizado. 
Os cálculos foram feitos através da fórmula (KIRKWOOD, 1988) :

$$
\mathrm{n}=\left[\left(\mathrm{z}_{1-\alpha}+\mathrm{z}_{1-\beta}\right) \sigma /\left(\mu_{1}-\mu_{0}\right)\right]^{2}
$$

Onde:

$\mathrm{z}_{1-\alpha}=$ valor da distribuição normal padronizada correspondente ao nível de significância de $\alpha$ (por exemplo, 1,96 para o teste bicaudal ao nível de significância 0,05).

$z_{1-\beta}=$ valor da distribuição normal padronizada correspondente ao nível desejado de poder (por exemplo, 0,84 para um poder de 80\%).

$$
\begin{aligned}
& \sigma=\text { desvio padrão } \\
& \mu_{1}=\text { média correspondente à hipótese alternativa } \\
& \mu_{0}=\text { média correspondente à hipótese nula }
\end{aligned}
$$

Para todos os cálculos foi utilizado o software STATA ${ }^{\text {TM }}$ (STATISTICS/DATA ANALYSIS), versão 7.0.

\subsubsection{Resultados do cálculo do tamanho da amostra:}

Utilizando-se como referência os valores da variação na pontuação do $\mathrm{BDI}$ nos pacientes que já completaram o estudo (média $=-2,7$ e desvio padrão $=3,9$ ) e os parâmetros descritos na metodologia foi construída a Tabela 7, que apresenta possíveis tamanhos de amostra para o estudo. 
Tabela 7 - Tamanhos de amostra para diferentes médias e respectivos desvios-padrão de variação de BDI

\section{Média de variação BDI Desvio padrão Tamanho da amostra}

\begin{tabular}{|c|c|c|}
\hline$-1,0$ & $\begin{array}{l} \pm 1,0 \\
\pm 2,0 \\
\pm 3,0 \\
\pm 4,0\end{array}$ & $\begin{array}{c}8 \\
32 \\
71 \\
126\end{array}$ \\
\hline$-1,3$ & $\begin{array}{l} \pm 1,0 \\
\pm 1,5 \\
\pm 2,0 \\
\pm 3,0 \\
\pm 4,0\end{array}$ & $\begin{array}{c}5 \\
11 \\
19 \\
42 \\
75\end{array}$ \\
\hline$-2,0$ & $\begin{array}{l} \pm 1,0 \\
\pm 2,0 \\
\pm 3,0 \\
\pm 4,0\end{array}$ & $\begin{array}{c}2 \\
8 \\
18 \\
32\end{array}$ \\
\hline$-2,5$ & $\begin{array}{l} \pm 1,0 \\
\pm 2,0 \\
\pm 3,0 \\
\pm 4,0\end{array}$ & $\begin{array}{c}2 \\
6 \\
12 \\
21\end{array}$ \\
\hline$-2,7$ & $\begin{array}{l} \pm 1,0 \\
\pm 2,0 \\
\pm 3,0 \\
\pm 4,0\end{array}$ & $\begin{array}{c}2 \\
5 \\
10 \\
18\end{array}$ \\
\hline$-3,0$ & $\begin{array}{l} \pm 2,0 \\
\pm 3,0 \\
\pm 4,0 \\
\pm 5,0\end{array}$ & $\begin{array}{c}4 \\
8 \\
14 \\
22\end{array}$ \\
\hline
\end{tabular}




\subsection{Casuística}

No total, foram analisados dados referentes a 33 pacientes participantes desse estudo, 25 transexuais masculinos e oito transexuais femininos, com idades entre 18 e 63 anos, sem uso de medicação psiquiátrica, divididos em três grupos:

Grupo 1: pacientes de № 1 a 15 (15 transexuais masculinos);

Grupo 2: pacientes de oํ 16 a 23 (8 transexuais femininos);

Grupo 3: pacientes de oㅡ 24 a 33 (10 transexuais masculinos).

Essa divisão ocorreu por questões de homogeneização de gênero, estabelecimento de tamanho de grupo e disponibilidade de salas e horários do Serviço de Psicoterapia do IPq-HCFMUSP (uma das salas de atendimento era grande, mas a psicoterapia de grupo seria pouco eficaz com 25 pacientes; a outra sala não comportaria mais do que 10 pacientes e dois psicoterapeutas).

O número de indivíduos transexuais masculinos (25) e femininos (8) foi estabelecido em decorrência da compatibilidade com o número estabelecido pelo estudo do cálculo de tamanho da amostra, procura pública e espontânea pelo atendimento, pela permanência no grupo de psicoterapia pelo tempo mínimo de dois anos e por ser coerente com a proporção internacionalmente aceita de três transexuais masculinos para cada transexual feminino na população (BANCROFT, 1989; LANDÉN et al., 1996 (b); FERREIRA, 2000).

A caracterização demográfica encontra-se reproduzida na Tabela 8. 
Tabela 8 - Dados demográficos

\begin{tabular}{|c|c|c|c|c|c|}
\hline PAC. & $\begin{array}{l}\text { IDADE DE } \\
\text { INÍCIO }\end{array}$ & ORIGEM & RELIGIÃO & $\begin{array}{l}\text { PARCEIRO } \\
\text { CONJUGAL }\end{array}$ & $\begin{array}{l}\text { IDADE } \\
\text { INÍCIO } \\
\text { TRANS. }\end{array}$ \\
\hline 1 & 41 & NORDESTE & CANDOMBLÉ & 20 anos & 10 anos \\
\hline 2 & 25 & SP/INTERIOR & CATÓLICA & 2 anos & 10 anos \\
\hline 3 & 41 & NORDESTE & CATÓLICA & NÃO & 7 anos \\
\hline 4 & 22 & $\begin{array}{c}\text { MINAS } \\
\text { GERAIS }\end{array}$ & CATÓLICA & NÃO & 5 anos \\
\hline 5 & 39 & NORDESTE & ESPIRITA & NÂO & 6 anos \\
\hline 6 & 26 & SP/INTERIOR & CATÓLICA & 2 anos & 5 anos \\
\hline 7 & 20 & SP/INTERIOR & ESPÍRITA & NÃO & 6 anos \\
\hline 8 & 29 & SP/CAPITAL & CATÓLICA & NÂO & 12 anos \\
\hline 9 & 24 & SP/INTERIOR & CATÓLICA & 2 anos & 14 anos \\
\hline 10 & 39 & \begin{tabular}{|l|} 
NORDESTE \\
\end{tabular} & CATÓLICA & NÃO & 5 anos \\
\hline 11 & 24 & SP/INTERIOR & CATÓLICA & NÃO & 3 anos \\
\hline 12 & 32 & SP/CAPITAL & CATÓLICA & NÃO & 7 anos \\
\hline 13 & 44 & \begin{tabular}{|l|} 
SP/CAPITAL \\
\end{tabular} & CATÓLICA & NÃO & 5 anos \\
\hline 14 & 37 & $\begin{array}{l}\text { MINAS } \\
\text { GERAIS }\end{array}$ & CATÓLICA & NÃO & 6 anos \\
\hline 15 & 21 & SP/CAPITAL & S/RELIGIÃO & NÃO & 5 anos \\
\hline 16 & 24 & R.J. & CATÓLICA & NÂO & 5 anos \\
\hline 17 & 46 & SP/CAPITAL & CATÓLICA & NÂO & 6 anos \\
\hline 18 & 25 & SP/INTERIOR & CATÓLICA & 2 anos & 7 anos \\
\hline 19 & 23 & SP/CAPITAL & CATÓLICA & NÃO & 7 anos \\
\hline 20 & 25 & SP/CAPITAL & EVANGÉLICO & NÃO & 8 anos \\
\hline 21 & 33 & SP/INTERIOR & CATÓLICA & 3 anos & 7 anos \\
\hline 22 & 18 & SP/CAPITAL & CATÓLICA & 2 anos & 6 anos \\
\hline 23 & 26 & NORDESTE & CATÓLICA & 12 anos & 7 anos \\
\hline 24 & 63 & RJ & S/RELIGIÃO & NÃO & 7 anos \\
\hline 25 & 30 & SP/INTERIOR & S/RELIGIÃO & NÂO & 5 anos \\
\hline 26 & 30 & SP/INTERIOR & S/RELIGIÃO & NÃO & 7 anos \\
\hline 27 & 20 & SP/CAPITAL & ESPÍRITA & $\mathrm{NÃO}$ & 6 anos \\
\hline 28 & 36 & PARANÁ & ESPIRITA & NÂO & 4 anos \\
\hline 29 & 24 & SP/INTERIOR & ESPÍRITA & 2 anos & 5 anos \\
\hline 30 & 21 & $\begin{array}{c}\text { MATO } \\
\text { GROSSO DO } \\
\text { SUL }\end{array}$ & AGNÓSTICO & NÂO & 5 anos \\
\hline 31 & 31 & SP/INTERIOR & CATÓLICA & $\mathrm{NÂO}$ & BEBÊ \\
\hline 32 & 28 & NORDESTE & CATÓLICA & NÂO & 7 anos \\
\hline 33 & 30 & NORDESTE & CATÓLICA & 5 anos & 7 anos \\
\hline
\end{tabular}


Tabela 8 - Dados demográficos

continuação

\begin{tabular}{|c|c|c|c|}
\hline PAC. & $\begin{array}{l}\text { IDADE INÍCIO } \\
\text { HORM. }\end{array}$ & $\begin{array}{l}\text { IDADE INÍCIO } \\
\text { TRANSV. }\end{array}$ & SITUAÇÃO FAMILIAR \\
\hline 1 & 17 anos & 17 anos & $\begin{array}{l}\text { Pai ausente (falecido, não aceitava) } \\
\text { Mãe próxima (falecida, aceitava) }\end{array}$ \\
\hline 2 & 25 anos & 18 anos & $\begin{array}{l}\text { Pai ausente (falecido, não sabia) } \\
\text { Mãe próxima (aceita) }\end{array}$ \\
\hline 3 & 20 anos & 23 anos & $\begin{array}{l}\text { Pai ausente (não aceita) } \\
\text { Mãe ausente (não aceita) }\end{array}$ \\
\hline 4 & 20 anos & 17 anos & $\begin{array}{c}\text { Pai ausente (aceita) } \\
\text { Mãe próxima (falecida, não sabia) }\end{array}$ \\
\hline 5 & 17 anos & 15 anos & $\begin{array}{l}\text { Pai ausente (falecido, não aceita) } \\
\text { Mãe próxima (aceita) }\end{array}$ \\
\hline 6 & 20 anos & 20 anos & $\begin{array}{l}\text { Pai ausente (não sabe) } \\
\text { Mãe próxima (aceita) }\end{array}$ \\
\hline 7 & 20 anos & 19 anos & $\begin{array}{l}\text { Pai ausente (não aceita) } \\
\text { Mãe próxima (aceita) }\end{array}$ \\
\hline 8 & Não iniciou & Não iniciou & $\begin{array}{l}\text { Pai próximo (não aceita) } \\
\text { Mãe próxima (não aceita) }\end{array}$ \\
\hline 9 & 17 anos & 17 anos & $\begin{array}{l}\text { Pai distante (não aceita) } \\
\text { Mãe próxima (aceita) }\end{array}$ \\
\hline 10 & 27 anos & 22 anos & $\begin{array}{c}\text { Pai ausente (falecido, não aceitava) } \\
\text { Mãe próxima (aceita) } \\
\end{array}$ \\
\hline 11 & 17 anos & 17 anos & $\begin{array}{c}\text { Pai ausente (falecido, não aceitava) } \\
\text { Mãe próxima (aceita) }\end{array}$ \\
\hline 12 & 25 anos & 32 anos & $\begin{array}{c}\text { Pai ausente (falecido, não aceitava) } \\
\text { Mãe próxima (aceita) }\end{array}$ \\
\hline 13 & 40 anos & 44 anos & $\begin{array}{c}\text { Pai ausente (falecido, não sabia) } \\
\text { Mãe próxima (aceita) } \\
\text { (AUSTRÍACOS) }\end{array}$ \\
\hline$\overline{14}$ & 20 anos & 37 anos & $\begin{array}{l}\text { Pai ausente (não sabe) } \\
\text { Mãe ausente (não aceita) }\end{array}$ \\
\hline 15 & Não iniciou & 21 anos & $\begin{array}{l}\text { Pai próximo (aceita) } \\
\text { Mãe próxima (aceita) }\end{array}$ \\
\hline 16 & 24 anos & 22 anos & $\begin{array}{l}\text { Pai ausente (não aceita) } \\
\text { Mãe próxima (aceita) }\end{array}$ \\
\hline 17 & 46 anos & 14 anos & $\begin{array}{c}\text { Pai próximo (falecido, não aceitava) } \\
\text { Mãe próxima (aceita) }\end{array}$ \\
\hline 18 & 25 anos & 20 anos & $\begin{array}{l}\text { Pai ausente (não aceita) } \\
\text { Mãe próxima (aceita) }\end{array}$ \\
\hline 19 & 21 anos & 21 anos & $\begin{array}{l}\text { Filho adotivo, mãe próxima (aceita) } \\
\text { Pai próximo (falecido, não sabia) }\end{array}$ \\
\hline
\end{tabular}


Tabela 8 - Dados demográficos

continuação

\begin{tabular}{|c|c|c|c|}
\hline PAC. & $\begin{array}{l}\text { IDADE INÍCIO } \\
\text { HORM. }\end{array}$ & $\begin{array}{l}\text { IDADE INÍCIO } \\
\text { TRANSV. }\end{array}$ & SITUAÇÃO FAMILIAR \\
\hline 20 & 25 anos & 24 anos & $\begin{array}{c}\text { Pai ausente (aceita) } \\
\text { Mãe próxima (não aceita) }\end{array}$ \\
\hline 21 & 33 anos & 15 anos & $\begin{array}{l}\text { Pai ausente (falecido, não aceitava) } \\
\text { Mãe próxima (falecida, não sabia) }\end{array}$ \\
\hline 22 & 18 anos & 16 anos & $\begin{array}{l}\text { Filho adotivo, mãe próxima (aceita) } \\
\text { Pai ausente (nunca teve contato) }\end{array}$ \\
\hline 23 & 26 anos & 15 anos & $\begin{array}{l}\text { Pai próximo (falecido, não aceitava) } \\
\text { Mãe próxima (aceita) }\end{array}$ \\
\hline 24 & 30 anos & 20 anos & $\begin{array}{l}\text { Pai próximo (falecido, aceitava) } \\
\text { Mãe ausente (não aceita) }\end{array}$ \\
\hline 25 & 13 anos & 30 anos & $\begin{array}{l}\text { Pai ausente (não aceita) } \\
\text { Mãe próxima (aceita) }\end{array}$ \\
\hline 26 & 17anos & 15 anos & $\begin{array}{l}\text { Pai e mãe ausentes (não sabem) } \\
\text { (avó criou) }\end{array}$ \\
\hline 27 & 15 anos & 14 anos & Pai e mãe próximos (aceitam) \\
\hline 28 & 35 anos & 35 anos & Pai e mãe ausentes (não aceitam) \\
\hline 29 & 23 anos & 15 anos & Pai e mãe ausentes (não aceitam) \\
\hline 30 & 21 anos & 21 anos & $\begin{array}{c}\text { Pai ausente (autoritário, não sabe) } \\
\text { Mãe próxima (não sabe) }\end{array}$ \\
\hline 31 & 30 anos & 19 anos & $\begin{array}{l}\text { Pai ausente (não aceita) } \\
\text { Mãe próxima (aceita) }\end{array}$ \\
\hline 32 & 26 anos & 26 anos & Pai e mãe próximos (aceitam) \\
\hline 33 & 13 anos & 14 anos & $\begin{array}{l}\text { Pai ausente (não aceita) } \\
\text { Mãe próxima (aceita) }\end{array}$ \\
\hline
\end{tabular}


Tabela 8 - Dados demográficos

continuação

\begin{tabular}{|c|c|c|c|}
\hline PAC. & PROFISSÃO & FILHOS & USO FAIXA \\
\hline 1 & AUX.ENFERM. & 02 ADOTIVOS & $\overline{\mathrm{NÃO}}$ \\
\hline 2 & COSTUREIRA & NÄO & NÂO \\
\hline 3 & CABELEREIRA & NÂO & NÂO \\
\hline 4 & $\begin{array}{c}\text { ESTUDANTE SUP. (USP) } \\
\text { MATEMÁTICA }\end{array}$ & NÃO & NÃO \\
\hline 5 & CABELEREIRA & NÂO & NÂO \\
\hline 6 & ESTUDANTE UNIV. (USP) LETRAS & NÃO & NẪO \\
\hline 7 & ESTUDANTE $2^{\circ}$ GRAU & NÂO & NÂO \\
\hline 8 & S/OCUPAÇÃO & NÂO & NÃO \\
\hline 9 & S/OCUPAÇÃO & NÃO & NÃO \\
\hline 10 & PROMOTORA EVENTOS & NÃO & NÃO \\
\hline 11 & CABELEREIRA & NÃO & NÃO \\
\hline 12 & S/OCUPAÇÃO & NÂO & NÂO \\
\hline 13 & ENGENHEIRO AGRÔNOMO & NÃO & NÂO \\
\hline 14 & DECORADOR & NÃO & NÃO \\
\hline 15 & S/OCUPAÇÃO & NÃO & NẪO \\
\hline 16 & S/OCUPAÇÃO & NÃO & SIM \\
\hline 17 & PESQUISADOR & NÃO & SIM \\
\hline 18 & S/OCUPAÇÃO & NÂO & SIM \\
\hline 19 & $\begin{array}{c}\text { FORMADO EM PROPAGANDA E } \\
\text { MARKETING S/OCUPAÇÃO }\end{array}$ & NÃO & SIM \\
\hline 20 & $\begin{array}{c}\text { ESTUDANTE SUPERIOR / PROP.E } \\
\text { MARKETING }\end{array}$ & NÂO & SIM \\
\hline 21 & TÉCNICO EM GESSO HOSP. & NÃO & SIM \\
\hline 22 & S/OCUPAÇÃO & NÂO & SIM \\
\hline 23 & MOTOBOY / CABELEREIRO & NÃO & SIM \\
\hline 24 & APOSENTADA & 01 ADOTIVO & NẪ \\
\hline 25 & AUX.ENFERM. & NÂO & NÂO \\
\hline 26 & CABELEREIRO & 01 ADOTIVO & NÃO \\
\hline 27 & NẪ & NÃO & NÃO \\
\hline 28 & S/OCUPAÇÃO & $\begin{array}{l}02 \text { FILHOS } \\
\text { PRÓPRIOS }\end{array}$ & NÂO \\
\hline 29 & Atriz e Psicóloga & NÃO & NÃO \\
\hline 30 & ESTUDANTE TEATRO & NÃO & NÃO \\
\hline 31 & SECRETÁRIA & NÃO & NÃO \\
\hline 32 & $\begin{array}{l}\text { GERENTE DE CRÉDITO E } \\
\text { COBRANÇA }\end{array}$ & NÂO & NÂO \\
\hline 33 & COZINHEIRA EM CANTINA & NÃO & NÃO \\
\hline
\end{tabular}


Tabela 8 - Dados demográficos

\begin{tabular}{|c|c|c|c|c|}
\hline PAC. & $\begin{array}{c}\text { USO PRÓTESE } \\
\text { PENIANA }\end{array}$ & $\begin{array}{l}\text { APLICAÇÃO } \\
\text { SILICONE }\end{array}$ & HIV & PROSTITUIÇÃO \\
\hline 1 & NÃO & NÂO & NAिO & NÃO \\
\hline 2 & $\mathrm{NÃO}$ & $\mathrm{NÃO}$ & $\mathrm{NÃO}$ & $\mathrm{NÃO}$ \\
\hline 3 & NÂO & SIM & SIM & NÃO \\
\hline 4 & NÃO & $\mathrm{NÃO}$ & NÃO & $\mathrm{NÃO}$ \\
\hline 5 & NÃO & SIM & SIM & SIM \\
\hline 6 & NÃO & NÃO & NÂO & NÂO \\
\hline 7 & NÃO & NÃO & NÃO & NÃO \\
\hline 8 & NÂO & NÂO & NÂO & $\mathrm{NÂO}$ \\
\hline 9 & NÃO & NÃO & NÃO & SIM \\
\hline 10 & NÃO & NÃO & NÃO & NÃO \\
\hline 11 & NÂO & SIM & NÄO & SIM \\
\hline 12 & NÃO & NÃO & $\mathrm{NÃO}$ & NÃO \\
\hline 13 & NÃO & NÃO & NÃO & NÃO \\
\hline 14 & NÃO & NÃO & NÃO & NÃO \\
\hline 15 & NÂO & NÃO & NÃO & NÃO \\
\hline 16 & SIM & $\mathrm{NÂO}$ & NÂO & $\mathrm{NÂO}$ \\
\hline 17 & NÂO & NÂO & NÂO & NÂO \\
\hline 18 & NÃO & NÃO & NÃO & NÃO \\
\hline 19 & SIM & NÂO & NÂO & NÂO \\
\hline 20 & SIM & NÃO & NÃO & NÃO \\
\hline 21 & SIM & NÃO & NÃO & NÄO \\
\hline 22 & NÃO & NÂO & NÃO & NÃO \\
\hline 23 & SIM & NÃO & NÃO & NÂO \\
\hline 24 & NÃO & NÂO & NÃO & NÂO \\
\hline 25 & NÃO & $\mathrm{NÃO}$ & $\mathrm{NÃO}$ & SIM \\
\hline 26 & NÂO & SIM & NÂO & NÂO \\
\hline 27 & NÃO & NÃO & NÃO & NÃO \\
\hline 28 & NÃO & NÂO & NÂO & NÃO \\
\hline 29 & $\mathrm{NÃO}$ & $\mathrm{NA \tilde {O }}$ & NÂO & $\mathrm{NA \tilde {O }}$ \\
\hline 30 & NÃO & $\mathrm{NÃO}$ & $\mathrm{NÃO}$ & $\mathrm{NÃO}$ \\
\hline 31 & NÂO & NÂO & SIM & NÂO \\
\hline 32 & NÃO & SIM & SIM & SIM \\
\hline 33 & NÃO & SIM & NÃO & NÃO \\
\hline
\end{tabular}




\subsection{Metodologia da pesquisa}

Foi adotado o desenho de coorte prospectivo (HENNEKENS, BURING, 1987) para avaliar a evolução dos pacientes após a realização de dois anos de psicoterapia grupal.

Os estudos de coorte, também chamados longitudinais, iniciam com um grupo de indivíduos (uma coorte) que não apresenta a doença ou desfecho de interesse e que são classificadas em subgrupos de acordo com a exposição a um fator possivelmente associado à doença ou ao desfecho. As variáveis de interesse são especificadas e medidas e a coorte inteira é acompanhada para avaliar se 0 desenvolvimento subseqüente dos desfechos difere entre os grupos, conforme a presença ou não da exposição (BEAGLEHOLE et al., 2001).

No presente estudo, a coorte foi formada por indivíduos com diagnóstico de transexualismo avaliados quanto à presença de transtornos ou traços de transtornos de personalidade e de sintomas depressivos através de escalas psicopatológicas no início do estudo. Após dois anos de acompanhamento psicoterápico grupal, os participantes foram novamente avaliados através das mesmas escalas para a mensuração dos desfechos de interesse (presença de transtornos ou traços de transtornos de personalidade e de sintomas depressivos).

O estudo foi dividido em duas partes. A primeira consistiu em um estudo longitudinal em que, após intervenção psicoterápica grupal, cada paciente foi controle de si mesmo no que diz respeito à caracterização de Depressão e Transtorno de Personalidade. 
Essa medida se justifica dadas as particularidades da população e características da pesquisa que não viabilizavam um grupo de controle, pois qualquer que fosse ele, incorreria em questões relativas ao gênero desse mesmo grupo e comparações com o em estudo. Essa possiblidade tornaria pouco fidedignos os dados relativos aos possíveis transtornos e comparações decorrentes, levando em conta a presença da psicoterapia como fator modificador. Sabidamente, alguns estudos que caracterizam essa população psicopatologicamente abrem mão de grupos de controle (LOTHSTEIN, 1979; WISE, MEYER, 1980; SNAITH et al., 1993; ZUCKER et al., 1996; BROWN et al, 1996; COHEN-KETTENIS, VAN GOOZEN, 1997; COLE et al, 1997; YÜKSEL et al, 2000; DOCTER, FLEMING, 2001).

A segunda parte do estudo refere-se à evolução $e$ ao desenvolvimento do processo psicoterapêutico, além do levantamento das experiências de vida, que foram avaliados por metodologia qualitativa (TURATO, 2003). Segundo HAGUETTE (2000), " os métodos qualitativos enfatizam as especificidades de um fenômeno em termos de suas origens e de sua razão de ser".

A junção de conhecimentos acumulados tanto em bases objetivas quanto subjetivas é validada por MICHAELS (1997). Outros autores também celebram essa união, mas com ressalvas: "Embora sejam abordagens válidas, nem mesmo o sinergismo entre elas pode garantir a elucidação completa da verdade, da qual poder-se-ia alcançar grande proximidade, mas nunca domínio completo" (PEREIRA, 1999). 
O estudo, após apresentação e aprovação pela Comissão de Ética para Análise de Projetos de Pesquisa do HCFMUSP (CAPPesq), iniciou-se com a seleção da população. Foram inicialmente escolhidos 43 pacientes triados pelo PROSEX e com o diagnóstico de Transtorno de Identidade Sexual. O diagnóstico de transexualismo foi feito por meio dos critérios estabelecidos pelo DSM-IV, CID-10 e Conselho Federal de Medicina em suas resoluções no 1482/97 e 1652/2002.

A pesquisa, após caracterização diagnóstica, dividiu-se nas seguintes etapas:

1. Obtenção do termo de consentimento livre e esclarecido:

O termo de consentimento livre e esclarecido foi explicado e obtido do candidato em entrevista individual, explicitando o sentido de pesquisa do projeto e desvinculando diretamente este trabalho da realização da cirurgia de transgenitalização.

2. Anamnese individual:

A anamnese foi colhida em ambiente propício, nos preceitos éticos e da boa relação médico-paciente. Os dados foram utilizados para a caracterização demográfica dessa população.

Todos os pacientes foram caracterizados quanto a:

- idade;

- origem;

- religião;

- $\quad$ existência de parceria conjugal;

- $\quad$ idade de início de transexualismo; 
- $\quad$ idade de início de hormonização;

- $\quad$ idade de início de transvestismo;

- $\quad$ se é ou não aceito pelos pais;

- $\quad$ se tem os pais vivos;

- $\quad$ se é adotivo;

- profissão;

- $\quad$ se possui filhos;

- $\quad$ se utiliza faixa peitoral;

- $\quad$ se faz uso de prótese peniana;

- $\quad$ se aplicou silicone líquido ou possui prótese mamária;

- $\quad$ se é HIV + ou tem AIDS;

- $\quad$ se já se prostituiu.

A escolha desses quesitos se deu pela importância na singularização de cada indivíduo bem como pela importância no quadro clínico e estabelecimento de gênero e vida escolhidos.

O uso de faixa peitoral e prótese peniana se restringe à população transexual feminina. Já a aplicação de silicone industrial ou colocação de prótese mamária é específica da população transexual masculina.

3. Aplicação de entrevista estruturada para diagnóstico psiquiátrico: 
A entrevista estruturada para diagnóstico psiquiátrico escolhida foi a SCID-I/P (versão2.0) (FIRST et al, 1996) com tradução de Marcelo Tavares da Universidade de Brasília.

Sua finalidade é identificar e facilitar o diagnóstico nos estudos acadêmicos e, no caso específico desse trabalho, pesquisar possíveis comorbidades e excluir transtornos que possam de alguma forma ser diagnóstico diferencial com um possível Transtorno de Identidade Sexual como transtornos delirantes, oligofrenia, esquizofrenia e transtornos mentais orgânicos.

4. Aplicação de escalas específicas para pesquisa de Depressão e Transtorno de Personalidade:

A aplicação de escalas específicas para avaliação psiquiátrica foi realizada para caracterizar esse grupo em termos de traços e/ou transtorno de personalidade e depressão.

Foram elas: Inventário de Depressão de Beck, BDI, (BECK et al., 1961; versão revisada, BECK et al., 1979); Escala de Hamilton para Avaliação da Depressão (HAM-D 21 ítens) (HAMILTON, 1960) ; Entrevista Estruturada para Distúrbios da Personalidade pelo DSM-III-R (SIDP-R) (PFOHL et al., 1989, DEL PORTO et al., 1991).

Todas as escalas têm versão em português, estão validadas e foram aplicadas por pesquisador independente, psiquiatra, com familiaridade com esses instrumentos. A escolha por essas escalas se deve ao fato de serem reconhecidas, largamente 
utilizadas e de fácil aplicação. A escala de avaliação de personalidade, apesar da complexidade, é ampla e aprofunda a pesquisa a respeito de personalidade.

5. Início da psicoterapia psicodramática de grupo, com divisão dos pacientes em dois sub-grupos: masculino e feminino e com duração de dois anos. Foram formados dois grupos de psicoterapia com pacientes transexuais masculinos, devido ao maior número, e apenas um grupo de psicoterapia com os transexuais femininos:

O acompanhamento psicoterapêutico foi em psicoterapia psicodramática de grupo (MORENO, 1974), método e técnica psicoterapêutica já reconhecidos, para levantamento dos temas e caracterização psicodinâmica destas populações.

O atendimento psicoterapêutico foi realizado pelo pesquisador (psiquiatra) e por uma psicóloga com formação específica em Psicodrama, que formaram assim uma unidade funcional com componentes dos dois gêneros.

Os pacientes com Transtorno de Identidade Sexual masculino formaram dois grupos independentes dos pacientes com Transtorno de Identidade Sexual feminino, que integraram outro grupo. Segundo CUYPERE et al. (1995), esta separação é importante para a caracterização particularizada desses dois grupos e nesse caso, em particular, por questões de ordem prática já explicitadas. 
6. Estabelecimento do conteúdo e temário das sessões ao longo do processo psicoterapêutico:

A psicoterapia grupal desses indivíduos, pelas características especiais e por causa do estudo em questão, exigiu contrato específico. Por ser tópico fundamental em qualquer tipo de psicoterapia, o contrato com os grupos de transexuais adquiriu contornos únicos, dependentes de características dessa população.

Portanto, logo no início da psicoterapia grupal, estabeleceu-se:

- sigilo como condição primordial. Durante as sessões, muitas histórias pessoais surgiriam e o resgate desses episódios poderiam revelar questões e pessoas que deveriam ser resguardadas. Não haveriam encontros entre os participantes fora do contexto psicoterápico, preservando o clima psicoterapêutico e evitando variáveis relacionais fora do grupo;

- quórum mínimo estabelecido foi de três indivíduos para o grupo de transexuais femininos e de cinco para os de transexuais masculinos, devido ao maior número de pacientes transexuais masculinos em cada grupo e na viabilidade de uma sessão grupal;

- $\quad$ atrasos somente seriam aceitos em até 15 minutos após o horário estabelecido para o início da sessão; 
- número de faltas não foi limitado. Elas poderiam ser livres. Só não poderiam ocorrer três faltas injustificadas seguidas. O número total de faltas, porém, prolongaria o tempo final de permanência no grupo frente a possibilidade da indicação de cirurgia de redesignação sexual;

grupo teria duração mínima de dois anos (vinte e quatro meses) e não garantiria a indicação cirúrgica para nenhum dos integrantes;

as sessões teriam duas horas de duração e seriam semanais, nos horários agendados e contratados, durante vinte e quatro meses, no mínimo;

férias dos psicoterapeutas, feriados e suspensões de atendimentos estariam computadas dentro do período mínimo de vinte e quatro meses;

- grupo seria considerado fechado, ou seja, não entrariam novos pacientes, apenas sairiam os que porventura quisessem;

indicação cirúrgica ocorreria após um tempo mínimo de dois anos desde que o paciente fosse maior de idade (21 anos) na época da indicação, estivesse informado e consciente dos riscos e significados reais e fantasiosos da cirurgia, demonstrasse vida independente e real no 
gênero desejado, estabilidade psicológica e sexual, reavaliação e convivência com preconceitos sociais, etc.; após a indicação de cirurgia, o paciente deveria ser avaliado pelo grupo da endocrinologia, com posterior encaminhamento para a equipe cirúrgica;

- $\quad$ seguimento pós-cirúrgico seria obrigatório pelo período de um ano, com o paciente participando do grupo uma vez ao mês.

A seguir, iniciou-se o processo psicoterapêutico propriamente dito, com as sessões seguindo as diretrizes propostas no contrato e com esquema e temário de psicoterapia assim delineados:

Apresentação da unidade funcional e dos participantes do grupo e integração;

- Contrato: em que se estabeleceriam as bases de funcionamento da psicoterapia, como já explicitado;

- Sexualidade: histórico e significado;

Construção da identidade sexual: anterior e atual;

Esquema corporal: maneira de lidar com o corpo; higiene, prazer, percepção do formato corporal, significado do corpo atual e do idealizado;

- Vida afetivo-sexual: pregressa, atual e idealizada;

Família de origem: relacionamentos, conflitos, aceitação, preconceito na percepção do paciente; 
- Características específicas desta população: transvestismo, uso de hormônios sem controle médico, uso e aplicação de silicone, vida social dentro e fora do grupo transexual, luta pública como minoria ;

- Tentativas de suicídio ou auto-agressão;

- Solidão: característica da pessoa ou do quadro;

- Profissão: dificuldades e profissões mais comuns;

- Preconceito: próprio e do meio social;

- Sessões de orientação quanto às cirurgias: cronograma, tipos de cirurgia, riscos, pré- e pós-cirúrgico, necessidades de retoques cirúrgicos, número de cirurgias necessárias em cada caso;

- Sessão com a participação de transexual já operado: dúvidas, esclarecimentos, cobiça, adequação à realidade da situação pós-cirúrgica;

- Mudança de nome/questões legais: situação no Brasil e no mundo, perspectivas;

- Sessão com familiares: identificar conflitos e trabalhá-los;

- Sessões pré-cirúrgicas: ansiedades e receios, dúvidas;

- Sessões pós-cirúrgicas: o que mudou na vida, fantasias e realidade, adequação a nova configuração corporal, vida afetiva-sexual;

Sessões com temática aberta para o trabalho de conflitos ou questões não estabelecidos previamente. 
Para trabalhar e aprofundar tais temas, individualmente no grupo e com todo o grupo, foram utilizados:

- $\quad$ trabalho com protagonista e tema protagônico;

- técnicas clássicas do Psicodrama ( duplo, espelho e inversão de papéis);

- sociodrama e axiodrama (sociodrama que trabalha especificamente com temas éticos e morais);

- "role-playing";

- jogos dramáticos;

- $\quad$ sessões verbais.

7. Ao final dos vinte e quatro meses de psicoterapia grupal, reaplicação de escalas específicas para pesquisa de Depressão e Transtornos de Personalidade.

8. Análise dos dados:

Por fim, os dados obtidos tanto na aplicação das entrevistas e escalas, bem como durante a psicoterapia foram analisados e discutidos, assim como se fez a comparação entre os achados da amostra masculina e feminina, segundo testes e métodos estatísticos já estabelecidos na avaliação quantitativa e qualitativa propostos na metodologia.

A análise estatística foi dividida em análise descritiva e comparativa:

Análise Descritiva: 
Para as variáveis quantitativas (idade de início de tratamento, idade de início de transvestismo, idade de início do transexualismo etc.) esta análise foi realizada através da observação dos valores mínimos e máximos, e do cálculo de médias e desvios-padrão e medianas. Para as variáveis qualitativas (presença ou não de determinado parâmetro) foram calculadas as freqüências absolutas e relativas.

Análise Comparativa:

Para se testar a homogeneidade dos grupos, em relação às proporções apresentadas nos vários itens, foi utilizado o teste exato de Fisher, indicado para a comparação quando caselas de respostas apresentam freqüências esperadas menor do que 5 (ROSNER, 1986).

Para comparação entre os dois grupos foi empregado o teste não-paramétrico de Mann-Whitney para amostras independentes (ROSNER, 1986), aplicado quando a suposição de normalidade dos dados (exigida pelo teste t de Student) é rejeitada.

Para comparação das proporções inicial - final observadas no mesmo paciente foi utilizado o teste nãoparamétrico de McNemar (ROSNER, 1986), que é 
indicado para a comparação de proporções obtidas em amostras pareadas.

Para a comparação das médias inicial-final nos dois grupos avaliados foi empregada a Análise de Variância com medidas repetidas (TIMM, 1975), através da qual verificou-se se há, ou não, diferença entre os grupos em relação aos momentos avaliados, diferença entre os grupos e diferença entre as condições inicial e final.

A correlação entre as idades foi estudada através do coeficiente de correlação de Spearman (ROSNER, 1986). O nível de significância utilizado para os testes foi de $5 \%$. 


\section{RESULTADOS}


A apresentação dos resultados foi dividida em duas etapas. A primeira, a respeito da análise estatística, subdividida em análises descritiva e comparativa das características demográficas e as reveladas pelas escalas e entrevistas psiquiátricas pesquisadas nessa população. A seguir, são abordados dados qualitativos referentes à psicoterapia.

Para tanto, os pacientes foram divididos em três grupos:

Grupo 1: pacientes de números 1 a 15, transexuais masculinos;

Grupo 2: pacientes de números 16 a 23, transexuais femininos;

Grupo 3: pacientes de números 24 a 33, transexuais masculinos.

\subsection{Análise descritiva dos dados demográficos:}

1: Resultados:

Foram avaliados 33 pacientes com idades entre 18 a 63 anos, com média de 30,21 anos e desvio-padrão de 9,55 anos.

Em relação à origem desses pacientes, observa-se pela Tabela 9 que a maioria procede do interior e da capital do Estado de São Paulo e do nordeste. 
Tabela 9 - Freqüências absolutas e relativas da procedência dos pacientes

\begin{tabular}{lcc}
\hline Procedência & $\mathbf{n}$ & $\%$ \\
\hline SP/Interior & 11 & 33,3 \\
SP/Capital & 9 & 27,3 \\
Nordeste & 7 & 21,2 \\
Minas Gerais & 2 & 6,1 \\
Rio de Janeiro & 2 & 6,1 \\
Mato Grosso do Sul & 1 & 3,0 \\
Paraná & 1 & 3,0 \\
\hline
\end{tabular}

Em relação à religião deles, nota-se pela tabela 10 que a maioria declarou-se católica.

Tabela 10 - Freqüências absolutas e relativas da religião dos pacientes

\begin{tabular}{lcc}
\hline Religião & $\mathbf{n}$ & $\%$ \\
\hline Católica & 21 & 63,6 \\
Espírita & 5 & 15,2 \\
Sem religião & 4 & 12,1 \\
Agnóstico & 1 & 3,0 \\
Candomblé & 1 & 3,0 \\
Evangélico & 1 & 3,0 \\
\hline
\end{tabular}

Em relação às profissões desses pacientes, foram agrupadas segundo padrão social sexual prevalente em áreas com características femininas (cabelereira, costureira, secretária, etc.), masculinas (engenheira agrônoma, motoboy, técnico em gesso) ou neutra (pesquisador). Estudantes foram considerados como sem profissão. Na Tabela 11constata-se que a 
maioria declarou estar sem profissão. Os que trabalhavam, atuavam em profissões socialmente reconhecidas como de área feminina.

Tabela 11 - Freqüências absolutas e relativas da profissão dos pacientes

\begin{tabular}{lcc}
\hline Profissão & $\mathbf{n}$ & $\%$ \\
\hline Sem profissão & 16 & 48,5 \\
Área Feminina & 12 & 36,4 \\
Área Masculina & 3 & 9,1 \\
Área Neutra & 1 & 3,0 \\
Sem informação & 1 & 3,0 \\
\hline
\end{tabular}

Quanto à especificação da vida conjugal, familiar, desenvolvimento do transexualismo e outras características desses pacientes:

- $\quad$ em dez casos $(30,3 \%)$ observa-se a presença de parceiro com tempo médio de convivência igual a 5,2 anos, com desviopadrão de 6,07 anos e mediana de 2 anos, variação de 2 a 20 anos;

- a idade de início do transtorno de identidade sexual referida pelos pacientes variou de três a 14 anos, com média de 6,63 anos e desvio-padrão de 2,24 anos. Em um caso a idade de início relatada foi em bebê;

- $\quad$ em dois casos, a idade de início de uso de hormônios não foi relatada; nos demais há uma variação de 13 a 46 anos, com média de 23,41 anos e desvio-padrão de 7,59 anos e mediana de 21 anos; 
- a idade de inicio do transvestismo não foi relatada em um caso; nos demais, a variação foi de 14 a 44 anos com média de 21,09 anos e desvio-padrão de 7,31 anos e mediana de 19,50 anos;

em quatro casos $(12,1 \%)$, foi relatada a presença de filhos: dois com um filho adotivo, um com dois filhos adotivos e um com dois filhos naturais (todos transexuais masculinos, nenhum feminino);

em relação à convivência familiar, observou-se que em 23 dos casos $(69,7 \%)$, os pacientes relataram ter pai ausente e em cinco casos (15,2\%), a mãe era ausente. Em 12 casos (36,4\%) o pai era falecido e em três casos $(9,1 \%)$ a mãe. Em seis casos $(18,2 \%)$ o pai aceitava a identidade sexual do filho e em 22 casos $(66,7 \%)$ a mãe. Em dois casos $(6,1 \%)$, os filhos eram adotivos;

- $\quad$ em oito casos $(24,2 \%)$, observou-se a utilização de faixa para esconder os seios, em cinco $(15,2 \%)$ a utilização de prótese peniana (todos transexuais femininos) e em seis $(18,2 \%)$, a aplicação de silicone para aumento de mamas, coxas, nádegas ou transformação do rosto (todos transexuais masculinos). Em quatro casos $(12,1 \%)$ tem-se a presença de HIV e em cinco $(15,2 \%)$ a prostituição foi ou é praticada como forma de subsistência (todos transexuais masculinos). 


\subsection{Comparação dos grupos}

Os 33 pacientes avaliados foram divididos em dois grupos: o grupo do sexo feminino com oito $(24,2 \%)$ pacientes e o grupo do sexo masculino com $25(75,8 \%)$ pacientes.

1: Dados demográficos:

Em relação à idade (Tabela 12), os grupos não apresentaram diferença estatisticamente significativa:

Tabela 12 - Valores de média de idade, segundo os grupos masculino e feminino

\begin{tabular}{|c|c|c|}
\hline \multirow{3}{*}{ Variável } & \multicolumn{2}{|c|}{ Grupo } \\
\hline & Masculino & Feminino \\
\hline & $31,08 \pm 9,85$ & $27,50 \pm 8,54$ \\
\hline
\end{tabular}

Na Tabela 13, são apresentados os resultados obtidos em relação a alguns aspectos de vida e antecedentes pessoais dos pacientes: 
Tabela 13 - Comparação dos valores de freqüências absolutas e relativas dos antecedentes pessoais entre os grupos masculino e feminino

\begin{tabular}{|c|c|c|c|c|c|}
\hline \multirow{3}{*}{ Variável } & & \multicolumn{4}{|c|}{ Grupo } \\
\hline & & \multicolumn{2}{|c|}{ Masculino } & \multicolumn{2}{|c|}{ Feminino } \\
\hline & & $\mathrm{N}$ & $\%$ & $\mathrm{~N}$ & $\%$ \\
\hline Presença de & & 6 & 24,0 & 4 & 50,0 \\
\hline \multicolumn{6}{|l|}{ Parceiros } \\
\hline & Fem. & 11 & 45,8 & 1 & 12,5 \\
\hline Natureza da & Masc. & 2 & 8,4 & 1 & 12,5 \\
\hline \multicolumn{6}{|l|}{ Profissão } \\
\hline & Neutra & 0 & 0,0 & 1 & 12,5 \\
\hline & $\begin{array}{l}\text { Sem } \\
\text { ocupaçá }\end{array}$ & 11 & 45,8 & 5 & 62,5 \\
\hline
\end{tabular}

Ausência do Pai

Ausência da Mãe

Pai Falecido

Mãe Falecida

Aceitação do Pai

Aceitação da Mãe

Ser Filho Adotivo
1872,0

$5 \quad 62,5 \quad 0,673$

$5 \quad 20,0$

$0 \quad 0,0$

0,302

$8 \quad 32,0$

$4 \quad 50,0 \quad 0,420$

2

8,0

$1 \quad 12,5$

1,000

$5 \quad 26,3$

$1 \quad 16,7$

1,000

$16 \quad 72,7$

$6 \quad 85,7 \quad 0,646$

* nível descritivo de probabilidade do teste exato de Fisher.

Observa-se que os grupos não apresentaram diferenças significativas em relação a essas variáveis. 
$\mathrm{Na}$ Tabela 14 são descritas as idades de início das manifestações do transtorno de identidade sexual, a idade de início de uso hormônios e a idade de início de transvestismo.

Tabela 14 - Comparação dos valores de média das idades de início de transtorno de identidade sexual, transvestismo e uso de hormônios entre os grupos masculino e feminino

\begin{tabular}{|c|c|c|c|c|c|c|}
\hline \multirow{3}{*}{$\begin{array}{l}\text { Idade } \\
\text { Início do Transtorno de }\end{array}$} & \multicolumn{5}{|c|}{ Grupo } & \multirow{4}{*}{$\frac{p^{*}}{0,271}$} \\
\hline & \multicolumn{2}{|c|}{ Masculino } & \multicolumn{3}{|c|}{ Feminino } & \\
\hline & 6,36 & $\pm 2,83$ & 6,63 & \pm & 0,92 & \\
\hline Identidade Sexual & & & & & & \\
\hline Uso de Hormônio & 22,09 & $\pm \quad 6,87$ & 27,25 & \pm & 8,71 & 0,089 \\
\hline Início do Transvestismo & 22,00 & $\pm \quad 8,02$ & 18,38 & \pm & 3,81 & 0,382 \\
\hline
\end{tabular}

Observa-se que os grupos não diferem em relação a essas idades.

A idade de início de uso de hormônios está correlacionada com à idade de início de transvestismo no grupo masculino $\left(r_{s}=0,591, p=0,003\right)$ e não há correlação significativa destas idades no grupo feminino $\left(r_{s}=-\right.$ 0,627, $p=0,097)$, como pode-se observar no Gráfico 1 . 
Gráfico 1 - Correlações entre idade de início de uso de hormônios e início de transvestismo nos grupos masculino e feminino
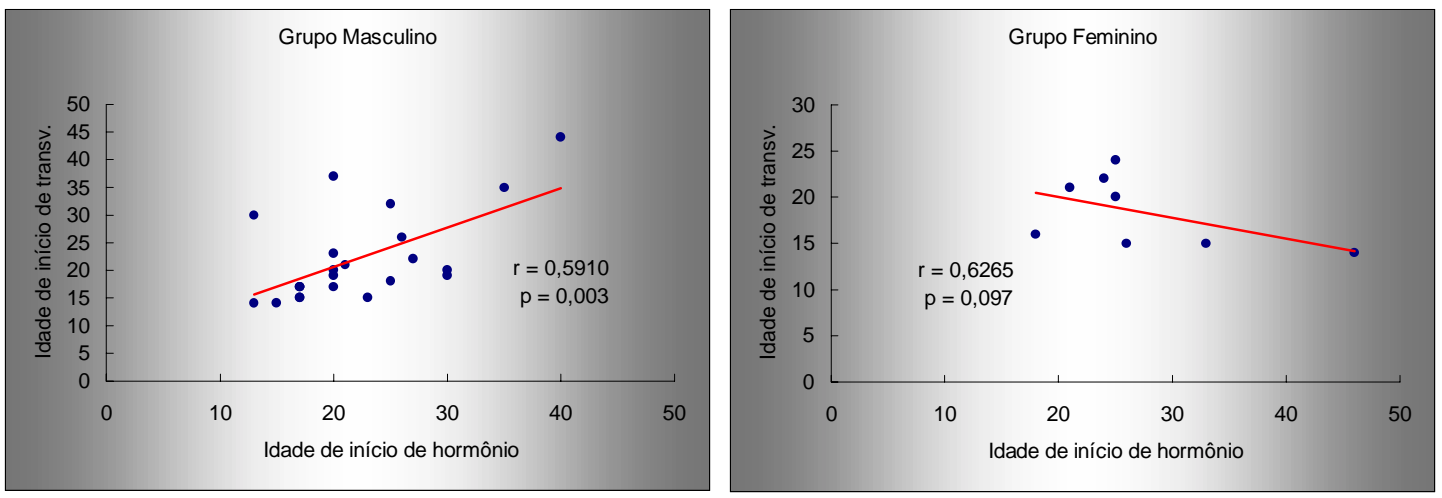

\subsection{Avaliação estatística da aplicação das entrevistas e escalas} psiquiátricas

As Tabelas 15, 16, 17 e 18 apresentam os resultados obtidos nas aplicações de escalas e entrevistas psiquiátricas e, na seqüência, é realizada a análise dos dados. 
Tabela 15 - Resultados das aplicações inicial e final de BDI e HAM-D por paciente

\begin{tabular}{|c|c|c|c|c|c|}
\hline PAC. & TRANS. & $\begin{array}{c}\text { BDI } \\
\text { INICIAL }\end{array}$ & $\begin{array}{c}\text { BDI } \\
\text { FINAL }\end{array}$ & HAM INICIAL & HAM FINAL \\
\hline 1 & masc. & 8 & 4 & 0 & 0 \\
\hline 2 & masc. & 6 & 4 & 0 & 0 \\
\hline 3 & masc. & 4 & 4 & 0 & 2 \\
\hline 4 & masc. & 1 & 1 & 5 & 1 \\
\hline 5 & masc. & 4 & 2 & 0 & 2 \\
\hline 6 & masc. & 2 & 2 & 1 & 3 \\
\hline 7 & masc. & 4 & 4 & 0 & 2 \\
\hline 8 & masc. & 23 & 22 & 11 & 17 \\
\hline 9 & masc. & 10 & 2 & 1 & 2 \\
\hline 10 & masc. & 10 & 1 & 0 & 1 \\
\hline 11 & masc. & 8 & 5 & 0 & 1 \\
\hline 12 & masc. & 24 & 5 & 12 & 7 \\
\hline 13 & masc. & 11 & 3 & 6 & 8 \\
\hline 14 & masc. & 6 & 7 & 0 & 2 \\
\hline 15 & masc. & 0 & 3 & 5 & 0 \\
\hline 16 & fem. & 18 & 7 & 3 & 1 \\
\hline 17 & fem. & 4 & 2 & 1 & 1 \\
\hline 18 & fem. & 13 & 3 & 0 & 0 \\
\hline 19 & fem. & 3 & 4 & 0 & 2 \\
\hline 20 & fem. & 6 & 5 & 10 & 0 \\
\hline 21 & fem. & 11 & 0 & 0 & 9 \\
\hline 22 & fem. & 12 & 4 & 6 & 0 \\
\hline 23 & fem. & 13 & 3 & 1 & 0 \\
\hline 24 & masc. & 17 & 0 & 1 & 4 \\
\hline 25 & masc. & 7 & 1 & 2 & 0 \\
\hline 26 & masc. & 14 & 7 & 1 & 2 \\
\hline 27 & masc. & 1 & 4 & 1 & 1 \\
\hline 28 & masc. & 0 & 0 & 0 & 2 \\
\hline 29 & masc. & 6 & 0 & 0 & 1 \\
\hline 30 & masc. & 1 & 6 & 0 & 5 \\
\hline 31 & masc. & 1 & 0 & 0 & 2 \\
\hline 32 & masc. & 7 & 0 & 0 & 0 \\
\hline 33 & masc. & 0 & 0 & 9 & 4 \\
\hline
\end{tabular}


Tabela 16 - Resultados da aplicação de SCID

\begin{tabular}{|c|l|}
\hline PAC. & \multicolumn{1}{|c|}{ SCID } \\
\hline 1 & Nada \\
\hline 2 & Nada \\
\hline 3 & Nada \\
\hline 4 & Nada \\
\hline 5 & Nada \\
\hline 6 & Nada \\
\hline 7 & Episódio depressivo maior no passado com remissão completa \\
\hline 8 & $\begin{array}{l}\text { Depressão atual com caract melancólicas } \\
\text { Distimia com início antes dos 21 } \\
\text { Abuso de álcool } \\
\text { Abuso de substância ao longo da vida (maconha) } \\
\text { Fobia específica situacional leve (altura) } \\
\text { Toc em remissão parcial }\end{array}$ \\
\hline 9 & Abuso de álcool,cocaína, cannabis. \\
\hline 10 & Nada \\
\hline 11 & Nada \\
\hline 12 & $\begin{array}{l}\text { Distimia } \\
\text { Episódio depressivo no passado }\end{array}$ \\
\hline 13 & Nada \\
\hline 14 & Nada \\
\hline 15 & Nada \\
\hline 16 & $\begin{array}{l}\text { Episódio Depressivo no passado } \\
\text { Transtorno de Pânico no passado } \\
\text { Fobia Social no passado } \\
\text { TOC no passado } \\
\text { Anorexia Nervosa restritiva no passado } \\
\text { Bulimia Nervosa purgativa no passado }\end{array}$ \\
\hline 17 & $\begin{array}{l}\text { Abuso de álcool passado } \\
\text { Fobia específica tipo situacional (avião) }\end{array}$ \\
\hline
\end{tabular}


Tabela 16 - Resultados da aplicação de SCID

conclusão

\begin{tabular}{|l|l|}
\hline 18 & Episódio depressivo maior passado \\
\hline 19 & Nada \\
\hline 20 & Episódio depresssivo maior atual.Tr.dep. Maior.rec. \\
\hline 21 & Nada \\
\hline 22 & Nada \\
\hline 23 & Episódio depressivo maior no passado \\
\hline 24 & Episódio dep maior no passado aos 13, 17, 47 e 59 anos de idade \\
\hline 25 & $\begin{array}{l}\text { Tentativa de suicídio aos } 17 \text { anos. } \\
\text { Dependência de álcool em remissão completa desde 1993 } \\
\text { Uso nocivo de cocaína }\end{array}$ \\
\hline 26 & Nada \\
\hline 27 & Nada \\
\hline 28 & Nada \\
\hline 29 & Nada \\
\hline 30 & Nada \\
\hline 31 & $\begin{array}{l}\text { Episódio depressivo maior no passado } \\
\text { Um episódio de nov/2001 a jan/2002 }\end{array}$ \\
\hline 32 & Nada \\
\hline 33 & $\begin{array}{l}\text { Episódio Depressivo Maior no passado (adolesc, 12) } \\
\text { Episódio Depressivo Maior no presente, atípico } \\
\text { Fobia Social (falar em público) } \\
\text { Fobia Específica (altura) subliminar }\end{array}$ \\
\hline
\end{tabular}


Tabela 17 - resultados da aplicação inicial da entrevista de personalidade SIDP-R

\begin{tabular}{|c|l|}
\hline PAC. & \multicolumn{1}{|c|}{ Personalidade inicial } \\
\hline 1 & Nada \\
\hline 2 & Traços: 2 esquizotípico; 3 evitador \\
\hline 3 & Traços: 2 evitador \\
\hline 4 & Traços: 3 histriônico \\
\hline 5 & Traços: 2 auto-destrutivo \\
\hline 6 & Preenche critérios para: paranóide; traços: 3 evitador \\
\hline 7 & Traços: 2 borderline; 2 passivo-agressivo \\
\hline 8 & Preenche critérios para: narcisista ; dependente \\
\hline 9 & Preenche critérios para: histriônico \\
\hline 10 & Preenche criterios para: narcisista; paranóide; histriônico \\
\hline 11 & Nada \\
\hline 12 & Traços: 2 esquizóide; 2 evitador \\
\hline 13 & Nada \\
\hline 14 & Traços: 4 obsessivo-compulsivo \\
\hline 15 & Nada \\
\hline 16 & Diagnóstico de Transtorno Misto de Personalidade: Preenche critérios \\
\hline 17 & para histriônico; dependente; passivo-agressivo; evitador. \\
\hline 18 & Nada \\
\hline 19 & Nada \\
\hline 20 & Traços: 5 antissocial \\
\hline 21 & Traços: 2 histriônico \\
\hline 22 & Traços: 2 dependente; 2 evitador; 2 auto-destrutivo \\
\hline 23 & Traços: 3 paranóide; 3 esquizotípico; 3 dependente \\
\hline 24 & Nada \\
\hline 25 & Preenche critérios para: histriônico. Traços: 3 esquizotípico \\
\hline 26 & Traços: 3 auto-destrutivo \\
\hline 27 & Nada \\
\hline 28 & Nada \\
\hline 29 & Nada. \\
\hline 30 & Nada \\
\hline 31 & Nada \\
\hline 32 & Nada \\
\hline 33 & Preenche critérios para: evitador \\
\hline & \\
\hline
\end{tabular}


Tabela 18 - Resultados da aplicação final da entrevista de personalidade SIDP-R

\begin{tabular}{|c|l|}
\hline PAC. & \multicolumn{1}{|c|}{ Person final } \\
\hline 1 & Nada \\
\hline 2 & Nada \\
\hline 3 & Nada \\
\hline 4 & Traços: 3 histriônico \\
\hline 5 & Nada \\
\hline 6 & Traços: 2 evitador \\
\hline 7 & Nada \\
\hline 8 & Preenche critérios para: evitador; passivo-agressivo; paranóide \\
\hline 9 & Traços: 2 borderline \\
\hline 10 & Preenche criterios para: histriônico \\
\hline 11 & Traços: 4 antissocial (antes dos 15 anos) \\
\hline 12 & Traços: 2 dependente \\
\hline 13 & Traços: 4 esquizotípico; 2 evitador. \\
\hline 14 & Preenche critérios para paranóide, dependente e histriônico. Traços: \\
\hline 15 & Traços: 3 esquizóide \\
\hline 16 & Traços: 4 obsessivo-compulsivo; 4 passivo-agressivo; 3 evitador \\
\hline 17 & Nada \\
\hline 18 & Nada \\
\hline 19 & Traços: passivo-agressivo 3 \\
\hline 20 & Nada \\
\hline 21 & Traços: 3 paranóide \\
\hline 22 & Nada \\
\hline 23 & Nada. \\
\hline 24 & Traços: 3 esquizóide; 3 histriônico; 3 anti-social; 3 narcisista. \\
\hline 25 & Nada. \\
\hline 26 & Preenche critérios para esquizóide. Traços: 3 auto-destrutivo \\
\hline 27 & Nada \\
\hline 28 & Nada \\
\hline 29 & Traços: 4 narcisista \\
\hline 30 & Traços: 4 passivo-agressivo \\
\hline 31 & Nada \\
\hline 32 & Nada \\
\hline 33 & Traços: 3 paranóide. \\
\hline & \\
\hline
\end{tabular}




\subsubsection{Comparação entre os grupos para as escalas e entrevistas para SCID-I/P, BDI e Ham-D}

Os grupos foram comparados em relação ao SCID. No grupo do sexo masculino oito pacientes (32,0\%) apresentavam algum diagnóstico pelo SCID e no grupo feminino, cinco (62,\%\%). Esses percentuais não apresentam diferença estatisticamente significativa (teste exato de Fisher, $\mathrm{p}$ $=0,213)$. Não houve diagnóstico prevalente que se configurasse como estatisticamente significativo.

Adotando os critérios de pontuação propostos para a Escala de Avaliação para Depressão de Hamilton (HAM-D) (MORENO, MORENO, 2000):

$\leq 7$ : normal;

8-13: depressão leve;

14-18: depressão moderada;

19-22: depressão grave;

$\geq 23$ : depressão muito grave.

E os propostos para o Inventário de Depressão de Beck (BDI) (GORENSTEIN, ANDRADE, 2000) para pacientes previamente diagnosticados:

<10: sem depressão, ou depressão mínima;

11-18: depressão leve ou moderada;

19-29: depressão moderada a grave;

30-63: depressão grave. 
Os grupos foram comparados em relação ao BDI inicial e ao Ham-D inicial:

Tabela 19 - Valores de freqüências absolutas e relativas de BDI e HAM-D inicial, segundo os grupos masculino e feminino

\begin{tabular}{|c|c|c|c|c|c|c|}
\hline & \multirow[b]{3}{*}{ Categoria } & \multicolumn{4}{|c|}{ Grupo } & \multirow[b]{3}{*}{$p^{*}$} \\
\hline & & \multicolumn{2}{|c|}{ Masculino } & \multicolumn{2}{|c|}{ Feminino } & \\
\hline & & $\mathrm{n}$ & $\%$ & $\mathrm{n}$ & $\%$ & \\
\hline Beck & $\leq 10$ & 20 & 80,0 & 3 & 37,5 & 0,036 \\
\hline Inicial & $>10$ & 5 & 20,0 & 5 & 62,5 & \\
\hline Hamilton & $<8$ & 22 & 80,0 & 7 & 87,5 & 1,000 \\
\hline Inicial & $\geq 8$ & 3 & 12,0 & 1 & 12,5 & \\
\hline
\end{tabular}

* nível descritivo de probabilidade do teste exato de Fisher.

Os grupos diferem em relação à porcentagem de casos com BDI inicial > 10, o grupo feminino apresenta porcentagem significativamente maior que o grupo masculino. Os grupos não diferem em relação ao Ham-D (Gráfico 2).

Gráfico 2 - Comparação de BDI e HAM-D iniciais nos grupos
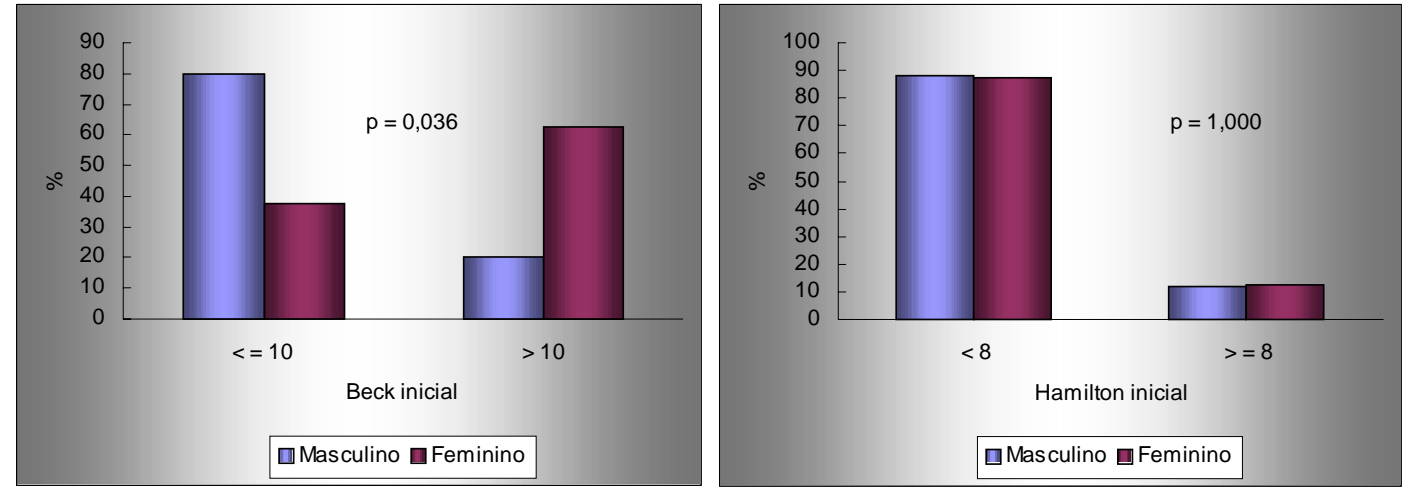
Estudando-se a associação entre BDI e Ham-D nos grupos (Tabela 20), observa-se que no grupo masculino, os que evidenciam BDI $\leq 10$, apresentam valores de Ham-D significativamente menores que os que apresentam BDI > 10. O mesmo não ocorre no grupo feminino.

Tabela 20 - Valores de média, dependendo do escore de HAM-D, segundo BDI inicial, nos grupos masculino e feminino

\begin{tabular}{lccc}
\hline \multirow{2}{*}{ Grupo } & \multicolumn{2}{c}{ Beck inicial } & \multirow{2}{*}{$\mathrm{p}^{*}$} \\
\cline { 2 - 3 } Masculino & $1,20 \pm 2,40$ & $6,20 \pm 5,26$ & 0,006 \\
Feminino & $2,00 \pm 2,55$ & $3,67 \pm 5,51$ & 0,878 \\
$\begin{array}{l}\text { * nível descritivo de probabilidade do Teste não-paramétrico de Mann- } \\
\text { Whitney }\end{array}$
\end{tabular}

O escore de BDI e o Ham-D foram avaliados no início e fim do protocolo e os resultados obtidos constam na Tabela 21:

Tabela 21 - Valores de média, dependendo dos escores de BDI e HAM-D, segundo os grupos masculino e feminino

\begin{tabular}{|c|c|c|c|c|c|c|c|}
\hline \multirow{3}{*}{$\frac{\text { Escore }}{\text { BDI }}$} & \multirow{3}{*}{$\begin{array}{l}\text { Momento } \\
\text { Início }\end{array}$} & \multicolumn{6}{|c|}{ Grupo } \\
\hline & & \multicolumn{3}{|c|}{ Masculino } & \multicolumn{3}{|c|}{ Feminino } \\
\hline & & 7,00 & \pm & 6,70 & 10,00 & \pm & 5,18 \\
\hline & Fim & 3,48 & \pm & 4,46 & 3,50 & \pm & 2,07 \\
\hline \multirow[t]{2}{*}{ Ham-D } & Início & 2,20 & \pm & 3,65 & 2,63 & \pm & 3,62 \\
\hline & Fim & 2,76 & \pm & 3,62 & 1,63 & \pm & 3,07 \\
\hline
\end{tabular}


Por meio da Análise de Variância com medidas repetidas (Gráfico 3) verificou-se que os grupos apresentam o mesmo comportamento em relação ao BDI, do momento inicial para o final $(p=0,200)$. Não há diferença significativa entre os grupos quanto aos valores do inicial e do final $(p=0,421)$. Há decréscimo significativo do BDI para os dois grupos $(p<0,001)$.

Também por meio da Análise de Variância com medidas repetidas, os grupos apresentam o mesmo comportamento em relação ao Ham-D, do momento inicial para o final $(p=0,300)$. Não há diferença significativa entre os grupos quanto aos valores do inicial e final $(p=0,778)$. Não há alteração significativa do Ham-D para os dois grupos $(p=0,798)$.

Gráfico 3 - BDI "versus" HAM-D
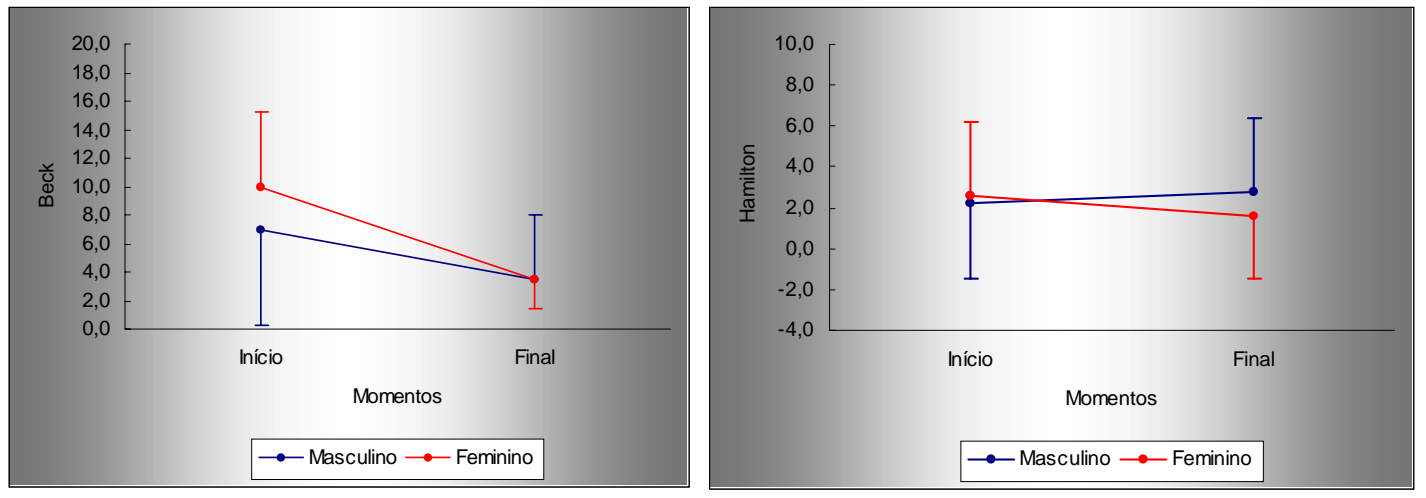

\subsubsection{Comparação entre os grupos para a entrevista de personalidade (SIDP-R)}

Os grupos foram comparados a partir dos resultados apresentados para os traços avaliados ou o preenchimento de critérios para a obtenção de diagnóstico de transtorno de personalidade. 
Em relação à avaliação de traços de personalidade:

1) No grupo como um todo: 19 (57,6\%) dos casos não apresentavam traços de personalidade no início do estudo e 14 $(42,4 \%)$, sim. Dentre os que não apresentavam traços, 10 $(52,6 \%)$ permaneceram assim e nove $(47,4 \%)$ os apresentaram no final do estudo. Dos que apresentavam, seis $(42,9 \%)$ continuaram e oito $(57,1 \%)$ deixaram de apresentar. Estas alterações não tiveram significância estatística (teste de McNemar, $p=0,808)$.

2) No grupo masculino: 15 (60,0\%) dos casos não apresentavam traços no início do estudo e 10 (40\%) sim. Dentre os que não apresentavam traços, oito $(53,3 \%)$ permaneceram assim e sete $(46,7 \%)$ passaram a apresentar no final do estudo. Dos que apresentavam, cinco $(50,0 \%)$ continuaram e cinco $(50,0 \%)$ deixaram de apresentar. Estas alterações não tiveram significância estatística (teste de McNemar, $p=0,564)$.

3) No grupo feminino: quatro $(50,0 \%)$ dos casos não apresentavam traços no início do estudo e quatro (50\%) sim. Dentre os que não apresentavam traços, dois $(50,0 \%)$ permaneceram assim e dois (50,0\%) passaram a apresentar traços no final do estudo. Dos que apresentavam, um $(25,0 \%)$ continuou e três $(75,0 \%)$ deixaram de apresentar. Estas 
alterações não tiveram significância estatística (teste de McNemar, $p=0,655)$.

Em relação à avaliação de diagnóstico de transtorno de personalidade, observou-se que:

1) No grupo como um todo: $26(78,8 \%)$ dos casos não apresentavam diagnóstico no início do estudo e sete $(21,2 \%)$ apresentavam. Dentre os que não apresentavam, 25 (92,3\%) permaneceram assim e um $(7,7 \%)$ apresentou diagnóstico no final do estudo. Dos que apresentavam diagnóstico, dois $(28,6 \%)$ permaneceram apresentando e cinco $(71,4 \%)$ deixaram de apresentar. Estas alterações não tiveram significância estatística (teste de McNemar, $p=0,257$ ).

2) No grupo masculino: 19 (76,0\%) dos casos não apresentavam diagnóstico no início do estudo e seis $(24,0 \%)$ sim. Dentre os que não apresentavam diagnóstico, 17 (89,5\%) permaneceram assim e dois $(10,5 \%)$ passaram a apresentar no final. Dos que apresentavam, dois $(33,3 \%)$ continuaram e quatro $(66,7 \%)$ deixaram de apresentar. Estas alterações não tiveram significância estatística (teste de McNemar, $p=0,414$ ).

3) No grupo feminino: sete $(87,5 \%)$ dos casos não apresentavam diagnóstico no início do estudo e um (12,5\%) sim. Todos os que não apresentavam permaneceram assim e a única exceção passou a não apresentar o diagnóstico no final do estudo. 


\subsection{Psicoterapia em grupo}

Iniciaram 0 processo psicoterapêutico 43 pacientes, todos informados e cônscios do termo de consentimento livre e esclarecido e avaliados pelas entrevistas e escalas psiquiátricas. O grupo todo era formado por 35 transexuais masculinos e oito transexuais femininos. Dos 43 iniciantes, a psicoterapia terminou, após dois anos, com 33 pacientes $(76,74 \%)$.

O primeiro grupo de transexuais masculinos foi inicialmente formado por 21 pacientes. Destes, seis $(28,57 \%)$ acabaram desistindo:

- $\quad$ um por mudança de cidade $(4,76 \%)$;

- $\quad$ três por abandono sem explicação $(14,28 \%) ;$

- dois para realização da cirurgia de redesignação em hospital particular (9,52\%). A primeira por ter mais de 60 anos e AIDS e a segunda por ansiedade. Ambas tinham condições financeiras que permitissem tal conduta.

O segundo grupo de transexuais masculinos foi formado inicialmente com 14 pacientes e quatro (28,57\%) não completaram dois anos de psicoterapia grupal. Três deles $(21,43 \%)$, por abandono sem explicação e um $(7,14 \%)$, por falecimento, devido à aplicação não acompanhada e nãomédica de silicone industrial nas mamas.

O grupo de transexuais femininos iniciou com oito pacientes e concluiu os dois anos com todos eles. Contudo, um deles logo após 
completar dois anos necessitou retornar à cidade de origem e abandonou o tratamento.

Serão considerados para análise de resultados os 33 pacientes que iniciaram e terminaram o acompanhamento psicoterapêutico em dois anos. Reservou-se para a discussão a questão do abandono desse processo por parte de $23,26 \%$ (10) dos pacientes que o iniciaram.

O número total de sessões variou de 80 a 84 sessões por grupo durante os vinte e quatro meses de duração, devido a férias da equipe psicoterapêutica e feriados, além de imprevistos que impediram a realização de algumas sessões.

Os grupos de psicoterapia apresentaram a distribuição e número de sessões apresentados na Tabela 22.

Tabela 22 - Distribuição e número de sessões grupais

\begin{tabular}{lc}
\hline \multicolumn{1}{c}{ GRUPOS } & $\begin{array}{c}\text { Número total de } \\
\text { Sessões }\end{array}$ \\
\hline Grupo 1: pacientes de 1 a 15; transexuais masculinos & 80 \\
Grupo 2: pacientes de 16 a 23; transexuais femininos & 84 \\
Grupo 3: pacientes de 24 a 33; transexuais masculinos & 84 \\
\hline
\end{tabular}

Quanto ao número de faltas (Tabela 23), variou muito de grupo para grupo e de indivíduo para indivíduo. As faltas computadas foram divididas entre justificadas, quando o paciente avisava que não poderia comparecer, e injustificadas, quando simplesmente não aparecia para a sessão. 
Tabela 23 - Distribuição de faltas por paciente

\begin{tabular}{|c|c|c|c|c|c|c|}
\hline PAC. & $\begin{array}{c}\text { FALTA } \\
\text { JUSTIFICADA }\end{array}$ & $\%$ & $\begin{array}{c}\text { FALTA } \\
\text { NÃO } \\
\text { JUSTIFICADA }\end{array}$ & $\%$ & $\begin{array}{c}\text { No TOTAL } \\
\text { DE FALTAS }\end{array}$ & $\begin{array}{c}\% \\
\text { TOTAL }\end{array}$ \\
\hline 1 & 14 & 17,5 & 7 & 8,75 & 21 & 26,25 \\
\hline 2 & 6 & 7,5 & 5 & 6,25 & 11 & 13,75 \\
\hline 3 & 5 & 6,25 & 5 & 6,25 & 10 & 12,5 \\
\hline 4 & 12 & 15 & 2 & 2,5 & 14 & 17,5 \\
\hline 5 & 6 & 7,5 & 19 & 23,75 & 25 & 31,25 \\
\hline 6 & 15 & 18,75 & 14 & 17,5 & 29 & 36,25 \\
\hline 7 & 20 & 25 & 8 & 10 & 28 & 35 \\
\hline 8 & 1 & 1,25 & 0 & 0 & 1 & 1,25 \\
\hline 9 & 20 & 25 & 12 & 15 & 32 & 40 \\
\hline 10 & 17 & 21,25 & 8 & 10 & 25 & 31,25 \\
\hline 11 & 10 & 12,5 & 21 & 26,25 & 31 & 38,75 \\
\hline 12 & 4 & 5 & 11 & 13,75 & 15 & 18,75 \\
\hline 13 & 0 & 0 & 0 & 0 & 0 & 0 \\
\hline 14 & 1 & 1,25 & 0 & 0 & 1 & 1,25 \\
\hline 15 & 5 & 6,25 & 11 & 13,75 & 16 & 20 \\
\hline 16 & 2 & 2,38 & 7 & 8,33 & 9 & 10,71 \\
\hline 17 & 7 & 8,33 & 11 & 13,1 & 18 & 21,43 \\
\hline 18 & 4 & 4,76 & 35 & 41,67 & 39 & 46,43 \\
\hline 19 & 12 & 14,29 & 10 & 11,9 & 22 & 26,19 \\
\hline 20 & 4 & 4,76 & 29 & 34,52 & 33 & 39,28 \\
\hline 21 & 2 & 2,38 & 0 & 0 & 2 & 2,38 \\
\hline 22 & 2 & 2,38 & 2 & 2,38 & 4 & 4,76 \\
\hline 23 & 2 & 2,38 & 0 & 0 & 2 & 2,38 \\
\hline 24 & 0 & 0 & 4 & 4,76 & 4 & 4,76 \\
\hline 25 & 1 & 1,19 & 27 & 32,14 & 28 & 33,33 \\
\hline 26 & 0 & 0 & 12 & 14,29 & 12 & 14,29 \\
\hline 27 & 2 & 2,38 & 28 & 33,33 & 30 & 35,71 \\
\hline 28 & 0 & 0 & 20 & 23,81 & 20 & 23,81 \\
\hline 29 & 4 & 4,76 & 29 & 34,52 & 33 & 39,28 \\
\hline 30 & 3 & 3,57 & 15 & 17,86 & 18 & 21,43 \\
\hline 31 & 4 & 4,76 & 10 & 11,9 & 14 & 16,66 \\
\hline 32 & 0 & 0 & 3 & 3,57 & 3 & 3,57 \\
\hline 33 & 0 & 0 & 0 & 0 & 0 & 0 \\
\hline
\end{tabular}


Pelo cruzamento de dados entre faltas justificadas e injustificadas, não foram encontrados resultados significativos, ou seja, o número de faltas não comprometeu o processo de psicoterapia se levados em consideração os resultados finais de BDI, HAM-D e traço ou diagnóstico de transtorno de personalidade.

Pela análise estatística, não houve correlação significativa entre as porcentagens de faltas justificadas ou injustificadas e as alterações de BDI e HAM-D para o grupo como um todo, para cada grupo em si nem para os grupos individualizados como transexuais femininos e masculinos.

Quanto ao critério traços e diagnóstico de transtorno de personalidade "versus" faltas justificadas e injustificadas, também não foi possível evidenciar significância considerando o grupo como um todo. A análise não pôde ser realizada dividindo-se por grupo pois o número de indivíduos não era suficiente para as comparações estatísticas.

Quanto ao temário das sessões, os grupos pouco variaram, mesmo levando em consideração a comparação entre os grupos de transexuais masculinos e o de transexuais femininos. O que variou especificamente foi a seqüência dos temas abordados e a profundidade das dicussões e exposições pessoais.

Após dois anos de psicoterapia grupal semanal, os assuntos abordados, trabalhados e vivenciados, reunidos em temas principais foram: 


\section{Preconceito:}

auto-preconceito;

- preconceito social.

\section{Fantasias:}

- fantasias quanto ao transexualismo;

- $\quad$ entrada na realidade de que não é homem/mulher de verdade;

- fantasias em relação à cirurgia.

\section{Dificuldades:}

- dificuldades relacionais com os familiares;

- dificuldade de aceitação paterna;

- $\quad$ aceitação materna;

- infância e escola;

- descobrimento da diferença: como foi, quando e como lidou com isso;

- adolescência;

- dificuldades profissionais;

- constrangimentos sociais.

\section{Comportamento Sexual:}

- comportamento sexual;

- namoro/parceria conjugal;

- $\quad$ agressividade; 
- público $X$ privado, em relação à sexualidade.

\section{Transexualismo:}

- $\quad$ transexualismo X indivíduo transexual;

- $\quad$ diferenças em características pessoais;

- $\quad$ ser homem X ser mulher;

- convivência grupal;

- indicação cirúrgica;

- critérios para cirurgia;

- $\quad$ ordem de indicação cirúrgica;

- imagem corporal;

- vivência corporal;

- convivência familiar;

- $\quad$ traição do/da parceiro/parceira;

- orientação sexual do parceiro do transexual masculino;

- $\quad$ transexual $X$ travesti $\mathrm{X}$ homossexual;

- romantismo e realidade do relacionamento humano e com um transexual;

- dificuldades e facilidades em se manter um relacionamento conjugal;

- diferenças de relacionamento conjugal entre transexuais masculinos e femininos. 


\section{Doenças Sexualmente Transmissíveis e Prostituição:}

HIV/ AIDS;

prostituição.

\section{Direitos e Cidadania:}

- direitos civis;

- $\quad$ mudança de nome e sexo jurídico;

- casamento após a cirurgia e relacionamentos em geral.

\section{Transexualismo, Cirurgia e Psicoterapia:}

- loucura e estranheza de ser transexual;

- preparação para a cirurgia;

- paciente operado, fantasias;

- $\quad$ conversas com paciente operado;

- $\quad$ seguimento pós-operatório em grupo;

- discussão da importância ou não da psicoterapia. Deve ser grupal ou individual?

Além desses temas principais serem recorrentes, questões pessoais relacionadas a fatores específicos da vida de cada participante e não necessariamente ligadas ao transexualismo como paixões, dificuldades sexuais e outras, foram trabalhadas nos três grupos.

Já temas como relacionamentos únicos, modo de se trajar, maquiagem, tipos de próteses penianas utilizadas, como esconder as 
mamas etc., foram situações levantadas e trabalhadas no contexto grupal específico dos três grupos.

Não considerando as especificidades relacionais de cada grupo, que acontecem e são importantes, no grupo de transexuais femininos os temas eram mais profundamente lidados e 0 interesse nesse aprofundamento se revelava nas discussões e mudanças expressas na vida.

Apesar de saberem que a psicoterapia era fundamental para a indicação cirúrgica, muitos transexuais masculinos após dois anos reinvidicavam o "direito adquirido" da cirurgia. Já no grupo de transexuais femininos, isso acontecia, mas com menor intensidade.

Muitos transexuais (masculinos e femininos, porém mais comum entre os masculinos) tentavam manipular os psicoterapeutas declarando o que eles achavam que a unidade funcional gostaria de ouvir. Tal estratégia não funcionava, pois não se sustentava por muito tempo e não se evidenciava mudança real e concreta nas atitudes e condutas fora da sessão. Além do quê, havia a denúncia grupal de que aquilo era uma farsa.

Outro dado interessante foi a coesão grupal maior entre transexuais femininos e menor entre os masculinos. Entre os últimos apesar de existir, a coesão se revelou superficial, não configurando relacionamento estável mas, sim, uma relação de interesse e momentânea. Já entre os transexuais femininos, as discussões, além de corriqueiras, promoviam mudanças e estabeleciam ligações fortes entre os membros do grupo.

Nos dois grupos a necessidade de ludibriar o contrato era freqüente, especificamente no tocante a contatos e encontros fora do "setting" 
psicoterapêutico. Sempre que "descobertos" pela unidade funcional, tais deslizes eram justificados por uma necessidade específica, momentânea e sem prejuízos para o funcionamento grupal. Todas as situações foram denunciadas e trabalhadas dentro de seu seus contextos pessoais e grupais.

Outra característica comum aos três grupos era a de que o primeiro ano de psicoterapia foi fundamental para a consolidação grupal e representou aquecimento preparatório para o segundo ano, quando se tornou possível o aprofundamento e trabalho dos temas já apresentados. A visão de que a unidade funcional estava contra eles e era preconceituosa como todo mundo apenas se desfez após esse primeiro ano. Então firmouse um contrato de respeito e reconhecimento profissional nas sessões. 
6 DISCUSSÃO 
A demanda espontânea pelo tratamento coincidiu, em linhas gerais, com a proporcionalidade encontrada por outros pesquisadores (PAULY, 1968; HOENIG, KENNA, 1974; TSOI, 1988; EKLUND et al., 1988; BAKKER et al., 1993; BANCROFT, 1989; WEITZE e OSBURG, 1996; LANDÉN et al., 1996 b; WILSON et al., 1999; FERREIRA, 2000) de cerca de três pacientes transexuais masculinos, para cada paciente transexual feminino (3:1).

No início do processo de avaliação a distribuição foi de 35:8, ou seja, uma média de 4,38:1 indivíduos masculinos para cada feminino e terminou com uma proporcionalidade de 25:8, o que perfaz uma média de 3,12:1 de transexuais masculinos em relação aos femininos.

Talvez a especificidade do diagnóstico revelasse o resultado encontrado por LANDÉN et al. (1996 b) de que a proporção entre homens e mulheres varia de 1:1 entre transexuais masculinos e femininos primários, até 4:1 entre homens e mulheres de um grupo com diagnóstico incerto.

O diagnóstico genérico de transtorno de identidade sexual ou de gênero foi, de maneira geral, simples, na medida em que é realizado pela presença de desejo expresso de mudança de gênero, mantido ao longo do tempo, com história clínica de inadequação ao sexo biológico e sem ter outro transtorno psiquiátrico associado. Já o diagnóstico de transexualismo, muito mais específico, revelou-se complexo. 
No intuito de facilitar a discussão, deixar claros os referenciais utilizados, dirimir dúvidas, e com base em vários autores (DEROGATIS et al., 1978; LEVINE, LOTHSTTEIN, 1981; ROBERTO, 1983; DOLAN, 1987; OMS, 1993; APA, 2000), utilizou-se como critérios para diagnosticar transexualismo:

Anamnese: história desde a infância de inadequação de gênero; quadro não relacionado à situação de estresse; ausência de sinais de fetichismo; experiências homossexuais raras e geralmente na fase de definição pessoal, quando descobre que não é adequado à categoria homossexual; vivência no gênero desejado sem conflitos; crença de que é heterossexual e de que é membro do gênero oposto ao seu sexo anatômico; busca da transformação hormonal e cirúrgica; repugnância pelos genitais e vontade de transformá-los; grande sofrimento psíquico por sua situação, com sintomas depressivos e história de auto-agressão, até mesmo suicídio.

- Desconforto e inadequação de gênero com duração de no mínimo dois anos;

- $\quad$ Vivência no papel de gênero desejado já estabelecida ou a se estabelecer durante o acompanhamento;

- $\quad$ Ausência de anormalidades genéticas ou interssexual;

- Não decorrente de quadro esquizofrênico, transtorno de humor psicótico, transtorno mental orgânico ou oligofrenia; 
- Busca real e intensa pela cirurgia, mas com a compreensão das dificuldades presentes na indicação desse recurso;

- $\quad$ Disponibilidade efetiva para psicoterapia como facilitador para a eventual indicação cirúrgica.

Para facilitar a discussão, a mesma foi dividida em cinco partes:

1. caracterização demográfica;

2. resultado do SCID-I/P;

3. resultados das aplicações da escala de avaliação para depressão de Hamilton e inventário de depressão de Beck;

4. resultados das aplicações da entrevista para transtorno de personalidade (SIDP-R);

5. análise da psicoterapia.

\subsection{Caracterização demográfica}

\section{A - origem}

Dos 33 pacientes considerados aptos a participar desse estudo, que iniciaram e terminaram todas as etapas propostas, $60,6 \%$ eram originários do Estado de São Paulo, sendo 33,3\% do interior e 27,3\% da capital. Se somado o valor de $39,4 \%$, referente aos nascidos em outros estados da federação, 72,7\% não nasceram na cidade de São Paulo, mas moram aí ou a procuraram para tratamento. Esses números além de revelarem um processo migratório importante por questões econômicas ou sociais, 
acrescentam a possibilidade desses indivíduos procurarem uma cidade grande em busca de maior aceitação. Situação muitas vezes não encontrada em seus estados ou cidades de origem.

\section{B - religião}

Em termos de religião, a grande maioria se auto-denominou católica (63,6\%), o que apenas pode revelar a inércia em se nomear católico, num país de colonização portuguesa e grande influência e predominância da Igreja Católica. Essa forma de se identificar religiosamente não revela prática nem rigor ritual no catolicismo, apenas criação nos preceitos dessa religião. Chama a atenção que o catolicismo não aceita nenhum fenômeno sexual que revele outras possibilidades de gênero ou comportamento que não sejam os estabelecidos pela Igreja. $E$ a lgreja não aceita 0 transexualismo como possibilidade de gênero. Outra religiões, como o candomblé ou o espiritismo, mais liberais no tocante à aceitação dessas manifestações humanas, vêm em segundo lugar com 18,2\% das autodenominações. Ainda $12,1 \%$ dizem não ter religião por não se sentirem aceitos nos dogmas religiosos e por sua condição os fazerem rever a noção de Deus e da religião como algo confortador segundo relatos pessoais.

Outra questão a ser lavada em conta é a do pequeno número de indivíduos pesquisados, o que não revela a possível pluralidade religiosa dessa população. 


\section{C - profissão}

A grande maioria $(48,5 \%)$ iniciou o tratamento sem profissão nem emprego. Tal número pode revelar a dificuldade de inserção dessa população no mercado de trabalho antes de qualquer tratamento. Não foi feito levantamento após dois anos de psicoterapia para evidenciar uma mudança desse aspecto. Muitas vezes, não é só o meio que impede um transexual de trabalhar mas sim, suas próprias dificuldades em lidar com seu transtorno de gênero e acreditar que possa ser aceito.

Chama a atenção o número de pacientes que freqüentam universidades (três; 9,99\% do total geral) e ensino médio profissionalizante (dois; $6,66 \%$ do total geral). Cada vez mais parece que a aceitação aumenta ou a discriminação diminui.

\section{D - vida conjugal}

Dos pacientes, 30,3\% apresentaram parceria com tempo médio de convivência de 5,2 anos. Isso pode revelar aceitação social maior que a esperada pois está-se avaliando questões afetivo-comportamentais e não meramente sócio-econômicas. Esse é um tópico a ser estudado até para comparar ou confirmar com as idéias e resultados de pesquisa de STEINER e BERNSTEIN (1981), BLANCHARD e COLLINS (1993) e LANDÉN e INNALA (2000) em relação aos parceiros e características dessas parcerias. 


\section{E - idade de início de manifestação do transexualismo}

O início da descoberta pessoal relatada do transtorno de identidade sexual foi aos seis anos de idade. Esse dado não é conflitante com o que autores psicanalistas postulam a respeito do Complexo de Édipo e suas implicações com o transexualismo (OVESEY e PERSON, 1973; PERSON e OVESEY, 1974; STOLLER, 1982; OPPENHEIMER, 1991; CHILAND, 2000; MICHEL et al., 2001). Essa foi também a idade de início de socialização escolar para muitos dos pacientes, o que pode estabelecer um parâmetro diferencial de comportamento entre os transexuais em criança e os outros.

\section{F - idade de início de uso de hormônios/idade de início de transvestismo}

Por viver no Brasil, onde informações sobre medicamentos não são acessíveis a todos e o preconceito e machismo são muito grandes, associado ao fato revelado de que a maioria dos pacientes não era originária de São Paulo, capital, ajuda a compreender a correlação entre idade de uso de hormônios idade de início de transvestismo. É a partir da idade média de 21 anos que o fenômeno se concretiza, levando o indivíduo a fazer uso dos hormônios e se transvestir no intuito de se aproximar fisicamente e socialmente do gênero desejado. Tal fato provavelmente ligado à maioridade e a provável separação da família, além da associação com outros transexuais ou mesmo travestis.

Não foram encontradas referências bibliográficas ou experiências similares em outros países. 


\section{G - filhos}

Apenas foi constatada a presença de filhos para os transexuais masculinos. Em três situações os filhos eram adotivos e em apenas uma os filhos eram naturais. A adoção revela a necessidade de se configurar como mãe e de se aproximar da figura feminina imaginada. Poder ter filhos e criálos como uma mulher concretiza parte da busca pela feminilidade. Já a paternidade transformada em maternidade demonstra grande dificuldade em se aceitar em um gênero e no outro, além do drama psíquico-familiar implícito, pois de pai torna-se mãe, disputando espaço com a mãe biológica e os filhos tendo que conviver com esse pai, perdido, transformado em outra mãe.

A respeito desse item, com a psicoterapia grupal, notou-se relação entre capacidade maternal e educacional com a maturidade psíquica, o que não difere em nada do restante da população heterossexual e sem problemas de identidade de gênero que é pai ou mãe. Não foi encontrada bibliografia correlacionando transexualismo com maternidade ou paternidade.

\section{H - aceitação materna e/ou paterna}

A aceitação materna e/ou paterna tem enorme importância para essa população, tanto para a definição do quadro, uma prerrogativa psicológica (OVESEY e PERSON, 1973; PERSON e OVESEY, 1974; STOLLER, 1982; OPPENHEIMER, 1991; CHILAND, 2000; FONSECA, 2000; MUTTI et al., 2000; MICHEL et al., 2001), quanto para a adequação social 
posterior. O fato da grande maioria revelar pai ausente $(69,7 \%)$ ou falecido $(36,4 \%)$, frente à mãe viva, presente e que aceita sua condição transexual, reforça as idéias dos autores ligados à Psicanálise e ao Psicodrama, citados acima, de que a influência familiar, especialmente a presença da mãe e a ausência do pai, são fatores determinantes para a manifestação ou expressão do transexualismo. Não se pode esquecer que o psicoterapeuta masculino foi chamado repetidas vezes e por vários pacientes de "pai" ou "modelo".

É curioso e necessita maior elucidação o fato de que dois transexuais femininos sejam adotados e os pais adotivos falecidos.

\section{I - uso de artifícios, presença de HIV e prostituição}

Quase um quarto dos transexuais $(24,2 \%)$, no caso todos os femininos, utiliza faixa para esconder as mamas. Mas nem todos utilizam prótese peniana, apenas cinco $(62,5 \%)$ dos oito transexuais femininos, ou $15,2 \%$ do total de transexuais. Chama a atenção o fato de que apenas seis pacientes (18,2\% do total), todos masculinos, fizeram aplicação de silicone em mamas, nádegas, coxas ou rosto.

Dos transexuais masculinos, cinco praticavam prostituição $(15,2 \%$ do total) e quatro são HIV positivos (12,1\% do total). O índice de prostituição diminuiu com o correr da psicoterapia, até porque a inserção social melhorou e a busca por novos papéis e possibilidades financeiras se tornou possível.

No decorrer do processo, não houve surgimento de novos pacientes HIV positivos, o que sugere maior cuidado e atenção com sua saúde e 
sexualidade Tal situação é compatível com os esquemas de esclarecimento, orientação e diminuição de riscos propostos para essa população por diversos autores (WIESSING et al., 1999; GREEN, 2000; LEE, 2000; CLARK et al., 2001; CLEMENTS-NOLLE et al., 2001; LOMBARDI, 2001 e MEYER, 2001).

\section{$\mathrm{J}$ - Comparação entre os grupos masculino $\mathrm{x}$ feminino}

Não houve diferenças significativas em nenhuma das variáveis pesquisadas, talvez porque os grupos se apresentem de maneira similar em relação a essas variáveis.

Por outro lado, existe correlação significativa entre idade de início de uso de hormônio com idade de início de transvestismo no grupo masculino. Ou seja, o início do uso de hormônios guarda correspondência temporal com o uso de roupas femininas. Talvez a busca pela feminilidade expressa pelo corpo e vestimentas tenha um início único. Aparentemente, o mesmo não acontece com os transexuais femininos.

Estudos comparativos entre transexuais femininos e masculinos, na literatura, em relação a esse tipo de dados não foram encontrados.

\subsection{Resultado do SCID-I/P}

Pelo fato de não se apresentar diferença estatística na presença de diagnósticos entre os grupos masculino e feminino, nem diagnóstico 
prevalente em nenhum dos grupos, fica aberta a questão psicopatológica. LEVINE e LOTHSTEIN (1981) encontraram 6\% de psicóticos entre homens candidatos à cirurgia de redesignação sexual e afirmam que as mulheres com disforia de gênero seriam mais saudáveis que os homens, o que não se evidenciou nos pacientes do presente estudo. Também não foi encontrado nenhum indivíduo com diagnóstico concomitante de esquizofrenia, o que não confirma os achados de COLE et al. (1997) que atribuem a esse diagnóstico o terceiro lugar entre os mais comuns entre indivíduos transexuais. $O$ presente estudo se aproxima, em relação aos resultados, à pesquisa desenvolvida por BROWN et al. (1996), que encontraram como diagnósticos mais freqüentes nessa população, depressão, ansiedade e abuso de substâncias químicas.

\subsection{Resultados das aplicações da escala de avaliação para depressão de Hamilton e inventário de depressão de Beck}

Depressão, considerada como diagnóstico e não apenas sintoma é comum em grande parte da população transexual estudada por ROBERTO (1983), BROWN et al. (1996) e COLE et al. (1997). Pelos resultados por nós obtidos, apenas dois pacientes transexuais masculinos (números 8 e 12) apresentavam depressão grave por HAM-D e moderada a grave por BDI e após dois anos a depressão evoluiu para leve a moderada (HAM-D e BDI). 
Pelo apresentado, os pacientes apresentaram sintomas depressivos e não quadros de depressão.

A maioria dos dois grupos apresentou HAM-D $<8$, mas em relação ao BDI apenas os transexuais masculinos na maioria apresentou índices $\leq$ 10, tendo a maior parte dos transexuais femininos obtido índices $>10$. Tal dado não pode ser considerado significativo, pois o número total de transexuais femininos foi considerado pequeno.

Um dado importante foi a presença de uma correlação de queda entre os índices de HAM-D e BDI do início para o final do tratamento nos dois grupos, o que revelou uma mudança causada pela psicoterapia grupal, já que nenhum outro fator terapêutico foi introduzido.

\subsection{Resultados das aplicações da entrevista para transtorno de personalidade (SIDP-R)}

Considerando que os diagnósticos de transtorno de personalidade e de gênero muitas vezes se superpõem (ROBERTO, 1983; BODLUND et al., 1993; COHEN et al., 1997; COLE et al., 1997; CAMPO et al., 2003) e apesar do número total de pacientes participantes desse estudo não poder revelar significância estatística, foram encontrados alguns resultados interessantes nesse aspecto.

Em relação aos traços de personalidade, no grupo como um todo houve decréscimo dos que apresentavam traços de personalidade do início 
para o fim da pesquisa. Contudo, houve em paralelo acréscimo daqueles que não apresentavam traços e passaram a apresentar. No grupo masculino houve aumento do número de indivíduos, enquanto no grupo feminino houve pequeno decréscimo dos que apresentavam traços de personalidade do início para o fim.

O diagnóstico de transtorno de personalidade, seguiu o mesmo padrão de queda, mas sem significância estatística. Os que, em sua maioria possuíam diagnóstico, deixaram de preencher critérios para eles após dois anos de psicoterapia grupal.

Os diagnósticos mais freqüentemente encontrados foram de transtorno de personalidade histriônico, evitador, esquizóide, dependente, passivo-agressivo e narcisista.

Um estudo com número maior de indivíduos pode possibilitar resultados com significado estatístico, considerando a influência da psicoterapia na indicação de diminuição de traços e transtornos de personalidade com maior número de pacientes evidenciando essa expectativa.

A possibilidade de indicação cirúrgica para transexuais com transtornos de personalidade deve ser tratada com cuidado. O risco de uma insatisfação é grande e possivelmente danosa para o paciente, programa e equipe de tratamento. Quanto à presença de traços, a psicoterapia tem a função de tratá-los antes da indicação cirúrgica. 


\subsection{Análise dos resultados da psicoterapia}

Partindo dos princípios anteriormente expostos segundo os quais a psicoterapia grupal é das mais indicadas para essa população (LOTHSTEIN, 1979; LOTHSTEIN, LEVINE, 1981; KELLER et al., 1982; STERMAC et al., 1991) e das diretrizes da HBIGDA (2001), foram obtidos resultados sólidos e positivos após dois anos de psicoterapia grupal com abordagem psicodramática.

Cada aspecto de cada sessão realizada conduzia aos fundamentos teóricos formulados em relação ao tema tanto pela Psicanálise quanto pelo Psicodrama.

Questões de relações parentais da grande maioria dos pacientes remetiam aos conceitos de PERSON e OVESEY (1974), STOLLER (1982), OPPENHEIMER (1991), CHILAND (2000) e MICHEL et al. (2001) pela Psicanálise e de FONSECA (2000) e MUTTI et al. (2000), pelo Psicodrama, especialmente no tocante à ausência paterna e à ligação simbiótica com a mãe, seja por dependência amorosa, seja por ódio.

Quanto às questões relativas à ansiedade, mentira, dificuldades de reconhecimento corporal e atitudes compatíveis com uma personalidade "borderline", autores como SOCARIDES (1970), OVESEY e PERSON (1973), VOLKAN e MASRI (1989), CARDER (1992), CHILAND (1998) e QUINODOZ (1998) esclareceram e anteciparam formulações teóricas e técnicas das quais lançou-se mão durante as sessões e na estruturação do temário final. 
Até mesmo em relação à dificuldade de estabelecer transferência com a unidade funcional no primeiro ano de psicoterapia, estudiosos como CARDER (1992), CHILAND (1998), QUINODOZ (1998), bem como OVESEY e PERSON (1973), PERSON e OVESEY (1974) e OPPENHEIMER (1991) facilitaram o trabalho, estabelecendo hipóteses de funcionamento e origem desse comportamento.

Quanto às sessões propriamente ditas, foram realizadas sempre em clima relativamente tranqüilo e de confiança nos três grupos, mas nos masculinos a desconfiança em relação à sinceridade de princípios da unidade funcional perdurou por mais de um ano.

Aos poucos, a percepção de que a função do grupo sempre foi a de melhorar a qualidade de vida de todos se instalou e eles puderam entender que a dificuldade de mudança de gênero, no aspecto social, psicológico, legal ou anatômico não é coisa simples e requer lidar com limites e impossibilidades.

Uma das primeiras grandes dificuldades na psicoterapia, além da conquista da confiança, foi trabalhar o auto-preconceito. Muitos chegavam se chamando de "aberração" ou "monstro" e colocando na Medicina a salvação ou a condenação ao seu estado. O preconceito social também foi muito trabalhado, visando que entendessem que para as pessoas, no dia-adia, é muito difícil perceber, aceitar e respeitar as diferenças entre transexualismo, transvestismo e homossexualidade.

Já é tarefa complicada, por exemplo, aceitar tranqüilamente um cheque ou um cartão de crédito. E se quem entrega esse cheque ou cartão 
se apresenta como um "travesti"? É preconceito, mas fundamentado em experiências sociais em que roubos, enganos são comuns e freqüentes. Quanto a ser "travesti", faz parte do imaginário popular a agressividade, marginalidade e imoralidade apregoadas desses indivíduos.

Entender que o outro não é obrigado a perceber e aceitar e que isso não significa necessariamente discriminação é um longo processo. Muitos buscam se aceitar a partir da aprovação alheia, o que é muito mais difícil, senão impossível.

melhor, e a busca da psicoterapia se dirigiu nesse sentido, é o indivíduo fortalecer-se em sua verdadeira identidade, revelando tranqüilidade e antecipando-se às situações, não para se justificar, mas para evitar constrangimentos às duas partes.

Outro aspecto que se mostrou enriquecedor foi o trabalho psicoterapêutico envolvendo as fantasias presentes no dia-a-dia em relação aos valores e conceitos construídos pelas famílias, religiões, sociedade, escola e o cotidiano de trabalho, estudos e relacionamentos. A influência dessas "instituições" formadoras de opinião e comportamento delimitou possibilidades e impossibilidades na vida desses sujeitos. Observar a construção de valores pessoais a partir dessas referências mostrou a riqueza de universo vivencial dos pacientes e possibilitou a libertação de regras, normas e atitudes pré-determinadas e pouco fundamentadas na vida de cada um deles.

Tema dos mais instigantes de ser trabalhado foi a questão da descoberta do transexualismo pelos familiares e a aceitação ou não 
decorrente. Cenas de violência física e/ou verbal, expulsão de casa desses pacientes ainda crianças ou adolescentes, rupturas de relacionamentos importantes, sobrevivência nas ruas com fome e frio, abrigo dado por terceiros, inclusive travestis, tudo isso pôde ser revivido e redimensionado.

A não-aceitação pela maioria dos pais e a aprovação e mesmo conivência afetiva das mães gerou situações e conflitos marcantes que se perpetuaram em vários momentos da vida desses indivíduos, mantendo bloqueio na expressão e desconfiança em vínculos conjugais e afetivos e mesmo na própria aceitação da situação específica em que vive.

Ligado ao tema anterior, o comportamento explicitamente sexualizado e muitas vezes provocante servia como defesa e agressão contra a não-aceitação e posterior discriminação do meio social. 0 transexual masculino faz de tudo para parecer ser mais mulher no vestir e na postura que muitas mulheres biológicas. O mesmo acontece com os transexuais femininos, nos quais qualquer deslize na voz, gestual ou expressão é entendido como sinal de menor masculinidade e, portanto, homossexualidade. Essa necessidade de afirmação e até mesmo confronto social foi objeto de nosso trabalho com modificação lenta e gradual.

O exterior, a maneira de falar, gesticular, vestir e se manifestar não deixa de ser um reflexo da tranqüilidade e maturidade psíquica. Quanto mais agressivo e provocador, quanto mais querelante, menos trabalhado e resolvido o indivíduo. Nesses casos, menos indicada é a cirurgia pois ela resolveria fantasiosamente uma questão que deve ser encarada como anterior a qualquer modificação definitiva, para não gerar dificuldades 
posteriores de adequação e encaixe social. A dificuldade maior não é externa, mas sim, interna, psicológica.

O comportamento sexual revelou também a maneira como os transexuais masculinos encaravam sua condição. O sexo anal é, via de regra, a forma eleita de realização sexual e a que mais se aproxima do sexo vaginal. Isso não exclui outros atos sexuais como oral, crural, masturbação etc.. Contudo, a maneira como o sexo anal é realizado, de bruços, excluindo qualquer contato visual ou face-a-face, realçando a falta de afeto e acentuando a agressividade, implica intranqüilidade e insatisfação.

A aversão à presença do pênis também pode ser entendida como dificuldade em se aceitar como transexual. Isso porque é a partir da experiência com esse órgão que vai ser construída sua nova identidade. Vale lembrar que a neovagina é fabricada, na maior parte dos casos, por meio das estruturas penianas. Se for mantida a enervação, a sensação de ser penetrada e o prazer decorrente virão de uma experiência anterior de tocar e estimular a pele peniana. A dificuldade de que seja vista como homossexual pelo parceiro pelo fato de possuir um pênis, é decorrente da fantasia de que seu parceiro não sabe ou não se importa de que possua um pênis. A questão verdadeiramente problemática foi o medo do parceiro querer tocar seu pênis, o que Ihes configurava perda de interesse e revelação de que o parceiro na realidade seria homossexual, o que não aceitam nem querem. Só aceitam parceiros heterossexuais, pois eles as confirmam como mulheres. 
De forma semelhante é o que se dá com os transexuais femininos, em que não retirar a faixa peitoral, ter relacionamento sexual de cuecas e usando uma prótese é a forma mais comum. Mesmo os que têm relacionamento longo, as parceiras sabendo de suas condições, têm muito medo de serem vistos como mulheres homossexuais.

A necessidade do reconhecimento exterior de que sejam pertencentes ao gênero desejado faz que a utilização de hormônios, mesmo sem indicação médica, seja freqüente. A transformação hormonal de um transexual feminino é estupenda, assemelham-se a homens com traços delicados, mas irreconhecíveis como mulheres que foram. Já para o transexual masculino a hormonioterapia consegue transformações limitadas, arredondando as formas, atenuando, mas mantendo os traços masculinos adquiridos na adolescência. A transformação é lenta e permite o trabalho psicoterapêutico seqüencial e progressivo.

Apenas aqueles pacientes transexuais masculinos que iniciaram hormonioterapia muito jovens são os que adquiriram traços femininos e dificilmente são confundidos com travestis.

Essa questão leva à pergunta de ser ou não adequado apagar a história anterior, a que revela seu gênero de origem.

Apagar a história de vida talvez não seja a saída para os transexuais. Se alguém nasce homem e vai se transformar em mulher, esse homem original é a peça fundamental na mudança. Esquecê-lo é perder parte de si e criar por fantasias e devaneios uma história irreal e imaginária. Um transexual, mesmo operado, jamais será uma mulher ou homem de 
verdade, no máximo vai se aproximar dessa possibilidade. Lidar com isso de forma concreta e presente apenas pode acrescentar e desenvolver saúde ao psiquismo dessas pessoas. Mantê-las na construção inventada ou simulada de uma realidade inexistente é o contrário da saúde. É estímulo à doença e à característica marcante dessa população de criar histórias, negar a realidade e inventar e desejar impossibilidades. Muitos transexuais masculinos falaram de seus úteros e de gravidez fantasiosa. Perpetuar a fantasia é o oposto do que deve ser feito.

Já questões referentes às doenças sexualmente transmissíveis e AIDS e mesmo prostituição são importantes de serem lidadas sem discriminação. Muitas vezes o recurso da prostituição é transitório e necessário para a sobrevivência. Em outros casos, existe prazer nesse tipo de trabalho, que deve ser validado, levado em conta e compreendido. A orientação quanto às doenças sexualmente transmissíveis deve acontecer independentemente ou apesar do contexto psicoterapêutico.

A importância da psicoterapia para essa população se traduz nas mudanças comportamentais e psíquicas e não no discurso desses pacientes. Esse é um grupo de pacientes que forçou muitas vezes à racionalização, o que foi evitado com muito cuidado, pois a racionalização é um perigo e um erro técnico. O discernimento em relação a isso se fez presente em temas como direitos, cidadania, cirurgia e pós-cirúrgico.

As questões de manejo e do próprio processo psicoterapêutico desse grupo de pacientes foram apenas alguns dos problemas enfrentados pelo psicoterapeuta com essa população. 
As dificuldades presentes no próprio papel profissional exercido envolvem a identidade de gênero, ocupacional e pessoal ao lidar com esses indivíduos. Eles remeteram a zonas profundas da própria existência e formação de valores da unidade funcional psicoterapêutica.

O início foi sempre estranho, diferente. Pois, logo de início, seus nomes dirigiam psicologicamente a um gênero pré-estabelecido. $E$ ainda existia a situação da não-transformação, o que remeteu os psicoterapeutas a situações em que deveriam usar nomes de um gênero para pessoas que pertenciam a outro. Era ir contra a percepção do real e significativo.

Por certo, trabalhar com transexuais estabeleceu o contrário a tudo que se estava acostumado, levando à releitura constante de paradigmas. E mais interessante, foi o trabalho conjunto com o grupo e com cada indivíduo, independente dos conceitos e valores iniciais da unidade funcional .

Daí a importância do grupo, para o não isolamento. Foi nesse lugar privilegiado que se deu a mudança. Um com os outros. Todos juntos.

A vivência psicodramática foi outro recurso a ser valorizado pois propiciou resgates, atualizações, "role-playings", vivências no sentido genérico do termo e finalizações importantes nas vidas dos pacientes.

Inclusive como auxiliar diagnóstico serviu. Uma vez que não existe método objetivo de diagnóstico para transexualismo, a psicoterapia pode funcionar com auxiliar pois permitiu estudar e entender fatos que em outras situações apenas seriam relatados, como período escolar, vida em família, ato sexual, etc.. 
Adicionalmente, a vivência psicodramática serve ao propósito de identificar quem estaria realmente preparado para a cirurgia. Feito o diagnóstico e realizada a psicoterapia é este o dilema que se impõe. Os pacientes muitas vezes tomam a unidade funcional como juiz tendencioso. Em psicoterapia grupal, o que se revela para todos é que as indicações para cirurgia seguem um fluxo natural no qual todos reconhecem os mais bem preparados. Isso não impede a inveja e sentimentos destrutivos dentro do grupo.

Cabe ainda ressaltar a importância da unidade funcional com os dois gêneros presentes pois isso propiciou identificações, estabelecimento de defesas e transferências importantes para o trabalho geral com os transexuais.

A figura masculina do psicoterapeuta para os dois tipos de transexualismo, foi importante. Talvez esteja ligada ao fato da ausência, abandono ou não-aceitação paterna.

Por fim, para aqueles transexuais masculinos que foram indicados para a cirurgia, a construção de uma neovagina foi considerada reconfortante pois Ihes permitiu viver a sensação de ser mulher e ter relações sexuais como se assim fossem. Já para os transexuais femininos o fato de terem as mamas e os órgão internos retirados produziu efeito semelhante. O problema continua sendo a neofaloplastia pois além de não ser funcional, pode não ter o aspecto de um pênis normal.

Foram 248 sessões com três grupos diferentes. O resumo aqui exposto reflete a generalização necessária, porém empobrecida, de tudo o 
que foi dito, vivido e revelado por todos esses 33 indivíduos e unidades funcionais. 


\section{CONCLUSÕES}




\section{$7 \quad$ CONCLUSÕES}

As conclusões às quais esse estudo levou foram:

1. Os transtornos de eixo I mais comumente encontrados tanto em transexuais masculinos quanto femininos foram: episódios depressivos no passado, transtornos de ansiedade e abuso de substâncias. Já os diagnósticos referentes a transtorno de personalidade mais freqüentemente encontrados foram de: transtorno de personalidade histriônico, evitador, esquizóide, dependente, passivo-agressivo e narcisista. Nenhum deles estatisticamente significativo, nem para o grupo como um todo, nem para cada grupo em específico.

2. Comparando os índices de depressão (BDI e HAM-D) obtidos pelos grupos de transexuais masculinos com o de transexuais femininos antes e após dois anos de psicoterapia grupal, houve decréscimo semelhante e melhora significativa estatisticamente em cada subgrupo e no grupo como um todo. Em relação aos transtornos de personalidade, houve um ligeiro decréscimo nos diagnósticos, mas não estatisticamente significativo no grupo como um todo nem em cada subgrupo. O número final de participantes frente à variedade diagnóstica possível, impossibilitou análise estatística. Um número maior de 
indivíduos no futuro permitirá um trabalho efetivo em relação a esse diagnóstico.

3. Vários dados demográficos foram encontrados na população estudada, desde origem, idade de início de transvestismo, idade de início de uso de hormônios, características familiares e conjugais, idade de início presuntiva das manifestações do transexualismo e outros. Cabe a tarefa de aprofundar quantitativa e qualitativamente o resultado obtido.

4. Poucas diferenças entre transexuais masculinos e femininos foram encontradas em relação aos dados demográficos, além daquelas referentes às características específicas como uso de silicone, faixa, prótese peniana e prostituição. Os perfis demográficos são muito semelhantes.

5. Foi pensado, estruturado e aplicado um temário específico para psicoterapia com essa população. Independentemente do referencial teórico dos psicoterapeutas esse eixo psicoterapêutico pode ser implementado pois reflete temas importantes na estabilidade psíquica dessa população e possibilita indicação segura para a cirurgia de redesignação sexual. 
8 REFERÊNCIAS BIBLIOGRÁFICAS 
8 REFERÊNCIAS BIBLIOGRÁFICAS

Ainda que mal pergunte, Ainda que mal respondas; Ainda que mal te entenda, Ainda que mal repitas; Ainda que mal insista, Ainda que mal desculpes; Ainda que mal me exprima, Ainda que mal me julgues; Ainda que mal me mostre, Ainda que mal me vejas; Ainda que mal te encare, Ainda que mal te furtes; Ainda que mal te sigas, Ainda que mal te voltes; Ainda que mal te ame, Ainda que mal o saibas; Ainda que mal te agarre, Ainda que mal te mates; Ainda assim te pergunto

$E$ me queimando em teu seio, Me salvo e me dano: amor. (CARLOS DRUMMOND DE ANDRADE - Ainda)

Abbe R. New method of creating a vagina in a case of congenital absence. Med Rec. 1898;54:836-8.

Althof SE. Name change: its significance among patients with gender dysphoria. Bull Menninger Clin. 1980;44(6):617-27.

Anchersen P. Problems of transvestism. Acta Psychiatr Scand Suppl. 1956;106:249-56. 
American Psychiatric Association. Diagnostic and statistical manual of mental diseases. 3rd ed. Washington (DC): APA; 1980.

American Psychiatric Association. Diagnostic and statistical manual of mental diseases: revision. 3rd ed. Washington (DC): APA; 1987.

American Psychiatric Association. Diagnostic and statistical manual of mental diseases. 4rd ed. Washington (DC): APA, 1994.

American Psychiatric Association. Diagnostic and statistical manual of mental diseases: text revision. 4rd ed. Washington (DC): APA; 2000.

Andrade CD. As impurezas do branco. Rio de Janeiro: Nova Aguilar; 1979.

Araujo LAD. A proteção constitucional do transexual. São Paulo: Saraiva; 2000.

Babinski S, Reyes A. Identity formation in adolescence: case study of gender identity disorder and treatment through an intermediate-care day hospital. Psychiatr Q. 1994;65(2):121-33.

Baldwin JF. Formation of an artificial vagina by intestinal transplantation. Am. J. Obstet. Gynecol. 1907;56:636-40. 
Ball J. Thirty years experience with transsexualism. Austr. NZ. Journal Med. 1981;15:39-43.

Bakker A., Kesteren PJM, Gooren LJG, Bezemer PD. The prevalence of transsexualism in the Netherlands. Acta Psychiatr Scand. 1993;87:237-8.

Bancroft J. Human sexuality and its problems. 2nd ed. Singapore: Longman; 1989.

Barlow DH, Abel GG, Blanchard BB. Gender identity change in transsexuals. Arch Gen Psychiatry. 1979;36(9):1001-7.

Beaglehole R, Bonita R, Kjellström T. Epidemiologia básica. 2a ed. São Paulo: Santos; 2001.

Beck AT, Ward $\mathrm{CH}$, Mendelson M, Mock J, Erbaugh G. An inventory for measuring depression. Arch Gen Psychiatry. 1961;(4):53-63.

Beck AT, Rush A.J, Shaw BF, Emery G. Cognitive therapy of depression. New York: Guilford; 1979.

Becker D, Mester R. Further insights into transsexualism. Psychopatology. 1996;29:1-6. 
Benjamin H. The transsexual phenomenon. New York: Julian Press; 1966.

Berquó ES, Souza JMP, Gotlieb SLD. Bioestatística. São Paulo: Pedagógica Universitária; 1981.

Blanchard R. A structural equation model for age at clinical presentation in nonhomosexual male gender dysphorics. Arch Sex Behav. 1994;23(3):31120.

Blanchard R, Clemmensen LH, Steiner BW. Heterosexual and homosexual gender dysphoria. Arch Sex Behav. 1987;16(2):139-52.

Blanchard R, Collins PI. Men with sexual interest in transvestites, transsexuals, and she-males. J Nerv Ment Dis. 1993;181(9):570-5.

Blanchard R, Steiner BW, Clemmensen LH, Dickey R. Prediction of regrets in postoperative transsexuals. Can J Psychiatry. 1989;34:43-5.

Bodlund O, Kullgren G, Sundbom E, Höjerback, T. Personality traits and disorders among transsexuals. Acta Psychiatr Scand. 1993;88:322-7.

Bosinski H, Peter M, Bonatz G, Arndt R, Heindenreich M, Sippell W, Wille R. A higher rate of hyperandrogenic disorders in female-to-male transsexuals. Psyconeuroendocrinology. 1997;22:361-80. 
Bower $\mathrm{H}$. The gender identity disorder in the DSM-IV classification: a critical evaluation. Aust N Z J Psychiatry. 2001;35(1):1-8.

Bradley SJ, Blanchard R, Coates S, Green R, Levine SB, Meyer-Bahlburg HFL, Pauly IB, Zucker KJ. Interim report of the DSM-IV subcommittee on gender identity disorders. Arch Sex Behav. 1991;20(4):333-43.

Brandão JS. Mitologia grega. v.2, 8a ed. Petrópolis: Vozes; 1997.

Brandão JS. Mitologia grega. v.3, 7a ed. Petrópolis: Vozes; 1997.

Brasil. Conselho Federal de Medicina. Resolução no 1652 de 6 de novembro de 2002. Dispõe sobre a cirurgia de transgenitalismo e revoga a Resolução CFM no 1482/97. Diário Oficial da União. Brasília (DF). 20022 dez; Seção $1: 80$.

Disponível em: http://www.portalmedico.org.br/php/pesquisa resolucao.php. Acesso em 14 de março de 2004.

Brown GR. A review of clinical approaches to gender dysphoria. J Clin Psychiatry. 1990;51(2):57-64.

Brown GR, Wise TN, Costa PT, Herbst JH, Fagan PJ, Schimidt CW. Personality characteristics and sexual functioning of 188 cross-dressing men. J Nerv Ment Dis. 1996;184(5):265-73. 
Bullough VL. Introduction. In: Hirschfeld MD. Transvestites: the erotic drive to cross-dress. Translated by Michael A. Lombardi-Nash. Buffalo: Prometheus Books; 1991. p.11-4.

Bullough VL. The contribuitions of John Money: a personal view. J. Sex. Res. 2003;40(3):230-6 .

Bullough B, Bullough VL. Transsexualism: historical perspectives, 1952 to present. In: Denny D, editor. Current concept in transgender ldentity. New York: Garland Publishing; 1998. p.15-34.

Cairns TS, De Villiers W. Vaginoplasty. S Afr Med J. 1980;57:50-5.

Caldwell C, Keshavan MS. Schizophrenia with secondary transsexualism. Can J Psychiatry. 1991;36:300-1.

Campo J, Nijman H, Merckelbach H, Evers C. Psychiatric comorbity of gender identity disorders: a survey among dutch psychiatrists. Am $J$ Psychiatry. 2003;160:1332-6.

Carder SL. The wish for a sex change. Int J Psychoanal. 1992;73(3):581-4.

Cauldwell D. Psychopathia transexualis. Sexology. 1949;16:274-80. 
Conselho Federal de Medicina (CFM). Resolução CFM no 1482, de 10 de setembro de 1997. Jornal do CREMESP. Ano XVII. 1997;(123):13.

Chang TS, Hwang WY. Forearm flap in one-stage reconstruction, 1987.

Chiland C. Transvestism and transsexualism. Int $J$ Psychoanal. $1998 ; 79(1): 156-9$.

Chiland C. The psychoanalyst and the transsexual patient. Int J Psychoanal. 2000;81(1):21-35.

Chivers ML, Bailey JM. Sexual orientation of female-to-male transsexuals: a comparison of homosexual and nonhomosexual types. Arch Sex Behav. 2000;29(3):259-78.

Clark ME, Landers S, Linde R, Sperber J. The GLBT health access project: a state-funded effort to improve access to care. Am J Public Health. $2001 ; 91(6): 895-6$.

Clements-Nolle K, Marx R, Guzman R, Katz M. HIV prevalence, risk behaviors, health care use, and mental health status of transgender persons: implications for public health intervention. $A m \mathrm{~J}$ Public Health. $2001 ; 91(6): 915-21$. 
Cohen L. The pleasures of castration: the postoperative status of Hijras, Jankhas and academics. In: Abramsom PR, Pinkerton SD, editors. Sexual nature, sexual culture. Chicago: The University of Chicago Press; 1995. p.276-304.

Cohen L, De Ruiters C, Ringelberg H, Cohen-Kettenis PT. Psychological functioning of adolescent transsexuals: personality and psychopathology. $J$ Clin Psychol. 1997;53(2):187-96.

Cole CM, O’boyle M, Emory LE, Meyer WJ. Comorbity of gender dysphoria and other major psychiatric diagnoses. Arch Sex Behav. 1997;26(1):13-26.

Coleman E, Bockting WO, Gooren L. Homosexual and bisexual identity in sex-reassigned female-to-male transsexuals. Arch Sex Behav. 1993;22(1):37-50.

Coluccielo ML. Unveiling the mystique of gender dysphoria syndrome. Nurs Forum, 1996;31(2):15-22.

Cohen-Kettenis PT, Gooren LIG. Transsexualism: a review of etiology, diagnosis and treatment. J Psychosom Res. 1999;46(4):315-33. 
Cohen-Kettenis PT, Van Goozen SHM. Sex reassignment of adolescent transsexuals: a follow-up study. J Am Acad Child Adolesc Psychiatry. $1997 ; 36(2): 263-71$.

Cohen-Kettenis PT, Wålinder J. Sex reassignment surgery in Europe: a survey. Acta Psychiatr Scand. 1987;75:176-82.

Cohen L, Ruiter C, Ringelberg H. Cohen-Kettenis, P.T. Psychological functioning of adolescent transsexuals: personality and psychopathology. $J$ Clin Psychol. 1997;53(2):187-96.

Colapinto J. Sexo trocado: a história real do menino criado como menina. Tradução de Beatriz Horta. Rio de janeiro: Ediouro; 2001.

Costa JF. A inocência e o vício: estudos sobre o homoerotismo. Rio de Janeiro: Redume-Dumará; 1992.

Costa RP. Os onze sexos: as múltiplas faces da sexualidade humana. São Paulo: Gente; 1994.

Costa-Santos J, Madeira R. Transsexualism in Portugal: the legal framework and procedure, and its consequences for transsexuals. Med Sci Law. $1996 ; 36(3): 221-5$. 
Couto ES. Transexualidade: o corpo em mutação. Salvador: Grupo Gay da Bahia; 1999.

Daskalos CT. Changes in sexual orientation of sex heterosexual male-tofemale transsexuals. Arch Sex Behav. 1998;27:605-13.

Davenport CW. A follow-up study of 10 feminine boys. Arch Sex Behav. 1986;15(6):511-7.

De Cecco JP. Definition and meaning of sexual orientation. J Homosex. $1981 ; 6: 51-67$.

De Cuypere G, Jannes C, Rubens R. Psychosocial functioning of transsexuals in Belgium. Acta Psychiatr Scand. 1995;91:180-4.

Denny D. Black telephones, white refrigerators: rethinking Christine Jorgensen. In: Denny D, editor. Current concepts in transgender identity. New York: Garland Publishing; 1998. p.35-44.

Derogatis LR, Meyer JK, Boland P. A psychological profile of the transsexual. II. The female. J Nerv Ment Dis. 1981;169(3):157-68.

Derogatis LR, Meyer JK, Vazquez N. A psychological profile of the transsexual. I. The male. J Nerv Ment Dis. 1978;166(4):234-54. 
Dewing P, Shi T, Horvath S, Vilain E. Sexually dimorphic gene expression in mouse brain precedes gonadal differentiation. Mol Brain Res. 2003;118(12):82-90.

Dickey R, Stephens J. Female-to-male transsexualism, heterosexual type. Two cases. Arch Sex Behav. 1995;24(4):439-45.

Docter RF. Transvestites and transsexuals: toward a theory of cross-gender behavior. New York: Plenum Press; 1990.

Docter RF, Fleming JS. Measures of transgender behavior. Arch Sex Behav. $2001 ; 30(3): 255-71$.

Dolan JD. Transsexualism: syndrome or symptom? Am J Psychiatry. 1987;32(8):666-73.

Doorn CD, Poortinga J, Verschoor AM. Cross-gender identity in transvestites and male transsexual. Arch Sex Behav. 1994;23(2):185-201.

Dörner G. Hormones and brain differentiation. Amsterdam: Elsevier; 1996.

Dörner G, Poppe I, Kolzsch J, Uebelhach R. Gene and enviroment dependent neuroendocrine etiogenesis of homosexuality and transsexualism. Exp Clin Endocrinol. 1991;98:141-50. 
Dreger AD. Hermaphrodites and the medical invention of sex. Massachusetts: Harvard University Press; 2000.

Durfee R, Rowland W. Penile. Second interdisciplinary symposium on gender dysphoria syndrome. Palo Alto: Stanford University Press; 1973.

Eicher W, Spoljar M, Cleve H, Murken J, Richter K, Stengel-Rutkowski B. HY antigen in transsexuality. Lancet. 1979;2:1137-8.

Eklund PLE, Gooren LJG, Bezemer PD. Prevalence of transsexualism in the Netherlands. Br J Psychiatry. 1998;152:638-40.

Eldh J. Construction of a neovagina with preservation of the glans penis as a clitoris in male transsexuals. Plast Reconstr Surg. 1993;91(5):895-900.

Ellis $\mathrm{H}$, editor. Studies in psychology of sex. v.2. New York: Random House; 1936.

Ferreira FD. Transtornos de identidade sexual. In: Abdo CHN. Sexualidade humana e seus transtornos. 2a ed. São Paulo: Lemos; 2000.

Ferraz FC. Perversão. 2a ed. São Paulo: Casa do Psicólogo; 2002. 
First MB, Gibbon M, Sptizer RL, Williams JBW. Structured clinical interview for DSM-IV, patient edition, SCID-I/P. Washington (DC) American Psychiatric Press Inc.; 1996.

Fisk N. Gender dysphoria syndrome (the how, what and why of the disease). In: Laub D, Gandy P, editors. Proceedings of the second interdisciplinary symposium on gender dysphoria syndrome. Palo Alto: Stanford University Press; 1973. p.7-14.

Fogh-Andersen P. Transvestism and transsexualism. Acta Med Leg Soc (Liege). 1956;9:33-40.

Fonseca J. Psicodrama da loucura. São Paulo: Ágora; 1980.

Fonseca J. Psicoterapia da relação: elementos de psicodrama contemporâneo. São Paulo: Ágora; 2000.

Forget $\mathrm{H}$, Cohen $\mathrm{H}$. Life after birth: the influence of steroid hormones on cerebral structure and function is not fixed prenatally. Brain Cog. 1994;26:243-8.

Freud S. Obras completas: tomo II. 3a ed. Traducción de Luiz LopezBallesteros y De Torres.Madrid: Editorial Biblioteca Nueva; 1973. 
Friedman DM. Uma mente própria. Tradução de Ana Luiza Dantas Borges. Rio de Janeiro: Objetiva; 2002.

Futterweit W, Weiss RA, Fagerstrom RM. Endocrine evaluation of 40 female to male transsexuals: increased frequency of polycystic ovarian disease in female transsexualism. Arch Sex Behav. 1986;15:69-78.

Garcia JC. Problemáticas da identidade sexual. São Paulo: Casa do Psicólogo; 2001.

Gewin V. A plea for diversity. Nature. 2003;422(6930):368-9.

Gillies H, Milland Jr RD. Genitalia. In: Gillies H, Milland Jr RD, organizators. The principles and art of plastic surgery. London: Butterworth; 1957. p.36988.

Gooren LJ, Kruijiver FP. Androgens and male behavior. Mol Cell Endocrinol. $2002 ; 198(1-2): 31-40$.

Gorenstein C, Andrade LHSG. Inventário de depressão de Beck propriedades psicométricas da versão em português. In: Gorenstein C, Andrade LHSG, Zuardi AW. editores. Escalas de avaliação clínica em psiquiatria e psicofarmacologia. São Paulo: Lemos; 2000. p.71-87. 
Gorzynski G, Katz J. The polycystic ovary syndrome. Arch Sex Behav. $1977 ; 6: 215-22$

Green JN. Além do carnaval: a homossexualidade masculina no Brasil do século XX. Tradução de Cristina Fino e Cássio Arantes Leite. São Paulo: UNESP, 2000.

Green R. Birth order and ratio of brothers to sisters intranssexuals. Psychol Med. 2000;(30):789-95.

Green R. Family co-occurrence of "gender dysphoria": ten sibling or parentchild pairs. Arch Sex Behav. 2000;29(5):499-507.

Green R. Mythological, historical and cross-cultural aspects of transsexualism. In: Denny D, editor. Current concepts in transgender identity. New York: Garland Publishing; 1998. p.3-14.

Green R, Fleming D. Transsexual surgery follow-up. Status in the 1990s. Annu Rev Sex Res. 1990;1(1):163-74.

Green R, Kaverne EB. The disparate maternal aunt-uncle ratio in male transsexuals: an explanation invoking genomic imprinting. $J$ Theor Biol. 2000;202(1):55-63. 
Green R, Stoller R. Two pairs of monozigotic (identical) twins discordant for gender identity. Arch Sex Behav. 1971;1:321-8.

Green R, Young R. Hand preference, sexual preference and transsexualism. Arch Sex Behav. 2001;30(6):565-75.

Gregersen E. Práticas sexuais. Tradução de Antonia Alberto de Toledo Serra e Edison Ferreira. São Paulo: Rosa; 1983.

Gromb S, Chanseau B, Lazarini HJ. Judicial problems related to transsexualism in France. Med Sci Law. 1997;37(1):27-31.

Hage JJ. Medical requirements and consequences of sex reassignment surgery. Med Sci Law. 1995;35(1):17-24.

Hage JJ, Karim RB, Bloem JJAM, Suliman HM, Van Alphen M. Sculpturing the neoclitoris in vaginoplasty for male-to-female transsexuals. Plast Reconstr Surg. 1994;93(2):358-64.

Haguette TMF. Metodologias qualitativas na sociologia. 7a ed. Petrópolis: Vozes; 2000.

Hamilton M. Rating scale for depression. J Neurol Neurosurg Psychiatry. 1960(23):56-62. 
Hart J. Therapeutic implications of viewing sexual identity in terms of essentialist and constructionist theories. J Homosex. 1984;9(4):39-51.

Harry Benjamin International Gender Dysphoria Association (HBIGDA). The standards of care for gender identity disorders. 6th version. The International Journal of Transgenderism. 2001;5(1). http://www.symposion.com/ijt/soc_2001/index.htm

Haussman BL. Changing sex: transsexualism, technology, and the idea of gender. Durhan: North Carolina; 1995.

Hepp U, Milos G. Gender identity disorder and eating disorders. Int J Eat Disord. 2002;32:473-8.

Hennekens $\mathrm{CH}$, Buring JE. Epidemiology in medicine. Boston/Toronto: Little, Brown and Company; 1987.

Hengstschläger M, Trotsenburg MV. Sex chromosome aberrations and transsexualism. Fertil Steril. 2003;79(3):639-40.

Herman-Jeglinska A, Grabowska A, Dulko S. Masculinity, feminility, and transsexualism. Arch Sex Behav. 2002;31(6):527-34. 
Hester TR, Hill HJ, Jurkiewicz MJ. One-stage reconstruction of the penis. $\mathrm{Br}$ J Plast Surg. 1978;31:279-85.

Hirschfeld M. Transvestites: the erotic drive to cross-dress. Translated by: Michael A. Lombardi-Nash. Buffalo: Prometheus Books; 1991.

Hoenig J, Kenna JC. The prevalence of transsexualism in England and Wales. Br J Psychiatry. 1974;124:181-90.

Hore B, Phil M, Nicolle F, Calman J. Male transsexualism: two cases in a single family. Arch Sex Behav. 1973;2:317-21.

Houaiss A, Villar MS. Dicionário Houaiss da língua portuguesa. Rio de Janeiro: Objetiva; 2001.

Huang TT. Twenty years of experience in managing gender dysphoric patients: I. Surgical management of male transsexuals. Plast Reconstr Surg. 1995;96(4):921-34.

Hugo V. Os miseráveis. Tradução de Frederico Ozanam Pessoa de Barros. São Paulo: Cosac \& Naif; 2002.

Hyde C, Kenna J. A male MZ twin pair, concordant for transsexualism, discordant for schizophrenia. Acta Psychiatr Scand . 1977;(56):265-75. 
Hyde JS. Understanding human sexuality. 5th edition. New York: McGrawHill; 1994.

Inacio M. Transexualidade e o Hospital das Clínicas de São Paulo. In: Ramsey G. Transexuais: perguntas e respostas. Tradução de Rafael Azize. São Paulo: Summus; 1998. p.194-6.

Irvine JM. Disorders of desire: sex and gender in modern american sexology. Philadelphia: Temple University Press; 1990.

Jurado J. Neocolpovulvoplastia na disforia de gênero. Anais do $26^{\circ}$ Congresso Brasileiro de Cirurgia Plástica. Santa Catarina; 1989.

Jurado J, Epps-Quaglia DR, Inácio M. Transsexualismo: aspectos clínicos e cirúrgicos. In: Coronho V, Petroianu A, Santana EM, Pimenta LG. Tratado de endocrinologia e cirurgia endócrina. Rio de Janeiro: Guanabara Koogan; 2001. p.1409-16.

Karim RB, Hage JJ, Mulder JW. Neovaginoplasty in male transsexuals: review of surgical techniques and recommendations regarding elegibility. Ann Plast Surg. 1996;37(6):669-75.

Keller AC, Althof SE, Lothstein LM. Group therapy with gender-identity patients a four-year study. Am J Psychother. 1982;36(2):223-9. 
Kessler SJ, Mckenna W. Gender: an ethinomethodological approach. Chicago: University of Chicago Press; 1985.

King B. The creation of a new science (introdution). In: Von Krafft-Ebing, R. Psycopathia Sexualis. Translation by Brian King. Burbank: Bloat; 1999.

Kirkwood BR. Essentials of medical statistics. Oxford: Blacwell Science Publications; 1988.

Kok LP. Management of sexual disorders. Singapore Med J. 1993;34:553-6.

Kramer H, Sprenger J. Manual da caça às bruxas. São Paulo: Edições de Planeta; 1973.

Kruijver FPM, Zhou JN, Pool CW, Hofman MA, Gooren LJG, Swaab DF. Male-to-female transsexuals have female neuron numbers in a limbic nucleus. J Clin Endocrinol Metab. 2000;85(5):2034-41.

Landén M, Innala S. Attitudes toward transsexualism in a swedish national survey. Arch Sex Behav. 2000;29(4):375-88.

Landén M, Walinder J, Lundström B. (b) Review article: prevalence, incidence and sex ratio of transsexualism. Acta Psychiatr Scand. 1996;93:221-3. 
Landén M, Walinder $J$, Lundström B. (a) Incidence and sex ratio of transsexualism in Sweden. Acta Psychiatr Scand. 1996;93:261-3.

Laqueur T. Inventando o sexo. Tradução de Vera Whately. Rio de Janeiro: Relume Dumará; 2001.

Laub DR. A surgical program and technique for male to female patients: discussion. In Laub DR, Gandy P, editors. Proceedings of the second interdisciplinary symposium on gender dysphoria syndrome. Palo Alto: Stanford University Press; 1973.

Laub DR, Fisk N. A rehabilitation program for gender dysphoria syndrome by surgical sex change. Plast Reconstr Surg. 1974;53:388.

Lee R. Health care problems of lesbian, gay, bisexual, and transgender patients. West J Med. 2000;172(6):403-8.

Levine SB. Gender-disturbed males. J Sex Marital Ther. 1993;19(2):131-41.

Levine SB, Lothstein L. Transsexualism or the gender dysphoria syndromes. J Sex Marital Ther. 1981;7(2):85-113.

Lief HI, Hubschman L. Orgasm in the postoperative transsexual. Arch Sex Behav. 1993;22(2):145-55. 
Lippa R. Gender-related traits in transsexuals and nontranssexuals. Arch Sex Behav. 2001;30(6):603-14.

Lobato MI, Henriques AA, Ghisolfi ES, Kegel S, Schestatsky G, Filho AC, Schestatsky SS. Transexualismo: uma revisão. J Bras Psiquiatr. 2001;50(1112):379-88.

Lombardi E. Enhancing transgender healthcare. Am J Public Health. $2001 ; 91(6): 869-72$.

Lothstein LM. Group therapy with gender-dysphoric patients. $A m J$ Psychother. 1979;33(1):67-81.

Maltz M. Maltz reparative technique for the penis. In: Maltz M. Evolution of plastic surgery. New York: Froben Press; 1946. p.278-9.

Manderson L, Kumar S. Gender identity disorders as a rare manifestation of schizophrenia. Aust N Z J Psychiatry. 2001;35(4):546-7.

Markland C, Hastings D. Vaginal reconstruction using cecal and sigmoid bowel segments in transsexual patients. J Urol. 1974;111:217-19.

Marks I, Green R, Mataix-Cols D. Adult gender identity disorder can remit. Compr Psychiatry. 2000;41(4):273-5. 
Marks IM, Mataix-Cols D. Four-year remission of transsexualism after comorbid obsessive-compulsive disorder improved with self-exposure therapy. Br J Psychiatry. 1997;171:389-90.

McCauley E, Ehrhardt AA. Follow-up of females with gender identity disorders. J Nerv Ment Dis. 1984;172(6):353-8.

Merengué D. Sexualidades e espontaneidade criadora. Revista Brasileira de Psicodrama. 1999;7(2):65-74.

Meyer JK. Clinical variants in applicants for sex reassignment surgery. Arch Sex Behav. 1974;3:527-58.

Meyer JK, Reter DJ. Sex reassignment: Follow-up. Arch Gen Psychiatry. 1979;3:1010-15.

Michaels S. Integrating quantitative and qualitative methods in the study of sexuality In: Bancroft J. Researching sexual behavior: methodological issues. Bloomington: Indiana University Press; 1997. p.299-308.

Meyer $\mathrm{IH}$. Why lesbian, gay, bisexual, and transgender public health? Am J Public Health. 2001;91(6):856-9. 
Michel A, Mormont C, Legros JJ. A psycho-endocrinological overview of transsexualism. Eur J Endocrinol. 2001;145(4):365-76.

Midence K, Hargreaves I. Psychosocial adjustment im male-to-female transsexuals: an overview of the research evidence. $J$ Psychol. 1997;131(6):602-14.

Minayo MCS. Desafio do conhecimento: pesquisa qualitativa em saúde. 7a ed. São Paulo-Rio de Janeiro: Hucitec-Abrasco; 2000.

Modestin J, Ebner G. Multiple personality disorder manifesting itself under the mask of transsexualism. Psychopathology. 1995;28:317-21.

Molina AM. Sefarad. Tradução de Rosa Freire d'Aguiar. São Paulo: Companhia das Letras; 2003.

Money J. The concept of gender identity disorder in childhood and adolescence after 39 years. J Sex Marital Ther. 1994;20(3):163-77.

Money J. Gay, straight, and In-between. New York: Oxford University Press; 1988.

Money J, Ehrhardt A. A. Man \& woman, boy \& girl. New Jersey: Jason Aronson Inc; 1996. 
Monstrey S, Hoebeke P, Dhont M, De Cuypere G, Rubens R, Moerman M, Hamdi M, Van Landuyt K. Surgical therapy in transsexual patients: a multidisciplinary approach. Acta Chir Belg. 2001;101:200-9.

Moore E, Wisniewski A, DOBS A. Endocrine treatment of transsexual people: a review of treatment regimens, outcomes, and adverse effects. J Clin Endocrinol Metab. 2003;88(8):3467-73.

Morales PA, O'Connor Jr JJ, Hotchkiss RS. Plastic reconstructive surgery after total loss of penis. Am J Surg. 1956;92:403-8.

Moreno JL. Psicoterapia de grupo e psicodrama. São Paulo: Mestre Jou; 1974.

Moreno JL. Psicodrama. 2a ed. São Paulo: Cultrix; 1978.

Moreno JL. Psicodrama. 9a ed. São Paulo: Cultrix; 1993.

Moreno RA, Moreno DH. Escalas de avaliação para depressão de Hamilton (HAM-D) e Montgomery-Äsberg (MADRS). In: Gorenstein C, Andrade LHSG, Zuardi AW, editors. Escalas de avaliação clínica em psiquiatria e psicofarmacologia. São Paulo: Lemos; 2000. p.71-87. 
Mormont C, Legros JJ, Michel A. A psycho-endocrinological overview of transsexualism. Eur J Endocrinol. 2001;145(4):365-76.

Mutti KR, Saadeh A, Abdo CHN. (Faculdade de Medicina da Universidade de São Paulo). Transsexualismo e psicodrama: uma proposta de entendimento. (Apresentado ao XII Congresso Brasileiro de Psicodrama; 2000; Águas de São Pedro, SP).

New M, Kitzinger E. Pope Joan: a recognizable syndrome (President's address). J Clin Endocrinol Metab. 1993;76(1):3-13.

Olsson SE, Möller AR. On the incidence and sex ratio of transsexualism in Sweden, 1972-2002. Arch Sex Behav. 2003;32(4):381-6.

Oppenheimer A. The wish for a sex change: a challenge to psychoanalysis? Int J Psychoanal. 1991;72(2):221-31.

Organização Mundial de Saúde. Classificação de transtornos mentais e de comportamento da CID-10: descrições clínicas e diretrizes diagnósticas. Porto Alegre: OMS; 1993.

Organização Mundial de Saúde. Classificação de transtornos mentais e de comportamento da CID-10: critérios diagnósticos para pesquisa. Porto Alegre: OMS; 1998. 
Orticochea M. A new method of total reconstruction of the penis. Br J Plast Surg.1972;25:347-66.

Ovesey L, Person ES. Gender identity and sexual psychopathology in men: a psychodynamic analysis of homosexuality, transsexualism, and transvestism (1973). In: Person ES. The sexual century. New York: Yale University Press; 1999. p.91-109.

Pauly IB. The current status of the change of sex operation. J Nerv Ment Dis. 1968;(147):460-71.

Pauly IB. Gender identity and sexual orientation. In: Denny D, editor. Current concepts in transgender identity. New York: Garland Publishing; 1998. p.23748.

Pereira JCR. Análise de dados qualitativos: estratégias metodológicas para as ciências da sáude, humanas e sociais. 2a ed. São Paulo: Edusp-Fapesp; 1999.

Person ES. The sexual century. New York: Yale University Press; 1999.

Person ES, Ovesey L. The transsexual syndrome in males: primary transsexualism (1974). In: Person ES. The sexual century. New York: Yale University Press; 1999. p.110-26. 
Person ES, Ovesey L. The transsexual syndrome in males: secondary transsexualism (1974). In: Person ES. The sexual century. New York: Yale University Press; 1999. p.127-45.

Pfohl B, Blum N, Zimmerman M, Stangl D. The structured interview for DSMIII-R personality disorders (SIDP-R). Iowa: University of lowa Hospitals and Clinics; 1989.

Platão O. O banquete; ou do amor. Tradução de Prof. J. Cavalcante de Souza. 8a ed. Rio de Janeiro: Bertrand Brasil; 1997.

Plummer K. Going gay: identities, life cycles and lifestyles in the male gay world. In: Hart J, Richardson D, editors. The theory and practice of homosexuality. Boston: Routledge \& Kegan Paul; 1981.

Puckett CL, Montie JE. Construction of male genitalia in the transsexual, using a tubed groin flap for the penis and hydraulic infation device. Plast Reconstr Surg.1978;61:523-30.

Puri BK, Singh I. The successful treatment of a gender dysphoric patient with pimozide. Aust N Z J Psychiatry. 1996;30(3):422-5.

Quinodoz D. A fe/male transsexual patient in psychoanalysis. Int $J$ Psychoanal. 1998;79(1):95-111. 
Raboch J, Kobilkowa J, Raboch J, Starka L. Sexual life of women with SteinLeventhal syndrome. Arch Sex Behav. 1985;14:263-70.

Rahman $Q$, Wilson GD. Sexual orientation and the $2^{\text {nd }}$ to $4^{\text {th }}$ finger length ratio: evidence for organising effects of sex hormones or developmental instability? Psychoneuroendocrinology. 2003;28:288-303.

Rakic Z, Starcevic V, Maric J, Kelin K. The outcome of sex reassignment surgery in Belgrade: 32 patients of both sexes. Arch Sex Behav. 1996;25(5): $515-25$.

Rehman J, Lazer S, Benet AE, Schaefer L, Melman A. The reported sex and surgery satisfactions of 28 postoperative male-to-female transsexual patients. Arch Sex Behav. 1999;28(1):71-84.

Rendleman N. False names. West J Med. 1998;169(5):318-21.

Reppen J. Mass sexuality / private sexuality. Int J Psychoanal. 1998;79(2):372-5 .

Roberto LG. Issues in diagnosis and treatment of transsexualism. Arch Sex Behav. 1983;12(5):445-73. 
Rosner B. Fundamentals of biostatistics. 2nd ed. Boston: PWS Publishers; 1986.

Ross MW, Walinder J, Lundstrom B, Thowe I. Cross-cultural approaches to transsexualism. A comparison between Sweden and Australia. Acta Psychiatr Scand. 1981;63:75-82.

Roughgarden J. A plea for diversity. Nature. 2003;422:368-9,

Rubin S. Sex-reassignment surgery male-to-female. Scand J Urol Nephrol Suppl. 1993;154:1-28.

Santi P, Berrino P, Canavese G, Galli A, Rainero ML, Badellino F. Immediate reconstruction of the penis using an inferiorly based rectus abdominalis myocutaneous flap. Plast Reconstr Surg. 1988;81:961-4.

Schaefer LC, Wheeler CC. Harry Benjamin's first ten cases (1938-1953): A clinical historical note. Arch Sex Behav. 1995;24(1):73-93.

Schooler L. O urso azul. Tradução de Marcos Santarrita. Rio de Janeiro: Objetiva; 2002.

Schreber DP. Memórias de um doente dos nervos. Tradução de Marilene Carrone. Rio de Janeiro: Edições Graal; 1984. 
Smith YLS, Cohen L, Cohen-Kettenis PT. Postoperative psychological functioning of adolescent transsexuals: a Rorschach study. Arch Sex Behav. 2002;31(3):255-61.

Snaith P, Tarsh MJ, Reid R. Sex reassignment surgery: a study of 141 dutch transsexuals. Br J Psychiatry. 1993;162:681-5.

Snyder CC, Browne Jr EZ. Intersex problems and hermafroditism. In: Converse JM. Reconstructive Plastic Surgery. 2nd ed. Philadelphia: Saunders; 1977. p.3941-9.

Socarides CW. A psychoanalytic study of the desire for sexual transformation ("transsexualism"): the plaster-of-Paris man. Int J Psychoanal. 1970;51:3419.

Sorensen T, Hertoft P. Male and female transsexualism: the danish experience with 37 patients. Arch Sex Behav 1982;11(2):133-55.

Statacorp. Stata statistical software: release 7.0. College Station: TX Stata Corporation; 2001.

Steiner BW, Bernstein SM. Female-to-male transsexuals and their partners. Can J Psychiatry. 1981;26(3):178-82. 
Stermac L, Blanchard R, Clemmensen LH, Dickey R. Group therapy for gender-dysphoric heterosexual men. J Sex Marital Ther. 1991;17(4):252-8.

Stoller RJ. Sex and gender. v.1. New York: Science House; 1969.

Stoller RJ. Sex and gender. New York: Aronson; 1974.

Stoller RJ. A experiência transsexual. Rio de Janeiro: Imago; 1982.

Stoller RJ, Baker H. Two male transsexuals in one family. Arch Sex Behav. 1972;2:323-8.

Swaab DF, Chun WC, Kruijiver FP, Hofman MA, Ishunina TA. Sexual differentiation of the human hypothalamus. Adv Exp Med Biol. 2002(511):75100.

Timm NH. Multivariate analysis with applications in educations and psychology. Monterrey: CA Brooks/Cole; 1975.

Thomas B. Gender loving care. Nurs Times. 1993;89(10):50-1.

Trevisan JS. Devassos no paraíso. São Paulo: Max Limonad; 1986. 
Tsoi WF. Follow-up study of transsexuals after sex-reassignment surgery. Singapore Med J. 1993;34:515-7.

Tsoi WF. The prevalence of transsexualism in Singapore. Acta Psychiatr Scand. 1988;78:501-4.

Tully B. Accounting for transsexualism and transhomosexuality. London: Whiting \& Birch Ltd; 1992.

Turan MT, Esel E, Dundar M, Candemir Z, Basturk M, Sofuoglu S, Ozkul Y. Female-to-male transsexual with 47,XXX karyotipe. Biol Psychiatry. 2000;48(11):1116-7.

Turato ER. Tratado da metodologia da pesquisa clínico-qualitativa. Petrópolis: Vozes; 2003.

Vaselý J, Haage J. From the history of penis reconstruction. Acta Chir Plast. 1999;41(2):43-5.

Volkan VD, Masri A. The development of female transsexualism. Am J Psycother. 1989;43(1):92-107.

Von-Krafft-Ebing R. Psychopathia sexualis. Translation by Peter O'Neil. Burbank: Bloat; 1999. 
Wachtel S, Green R, Simon N, Reichardt A, Cahil L, Hall J, Nokamura D, Wachtel G, Futterweit W, Biber S, Ihlenfield C. On the expression of $\mathrm{H}-\mathrm{Y}$ antigen intranssexuals. Arch Sex Behav. 1986(15):49-66.

Walinder J. Incidence and sex ratio of transsexualism in Sweden. $\mathrm{Br} J$ Psychiatry. 1971;119:195-6.

Weitze C, Osburg S. Transsexualism in Germany: empirical data on epidemiology and application of the german transsexuals' act during its first ten years. Arch Sex Behav. 1996;25(4):409-25.

Wiessing LG, Van Roosmalen MS, Koedijk P, Bieleman B, Houweling $\mathrm{H}$. Silicones, hormones and HIV in transgender street prostitutes. AIDS. $1999 ; 13(16): 2315-6$.

Wilson P, Sharp C, Carr S. The prevalence of gender dysphoria in Scotland: a primary care study. Br J Gen Pract. 1999;49(449):991-2.

Wise TN, Meyer JK. The border area between transvestism and gender dysphoria: transvestitic applicants for sex reassignment. Arch Sex Behav. $1980 ; 9(4): 327-42$.

Wise TN, Lucas J. Pseudotranssexualism: iatrogenic gender dysphoria. J Homosex. 1981;6(3):61-6. 
Wise TN, Meyer JK. The borders area between transvestism and gender dysphoria transvestitic applicants for sex reassignment. Arch Sex Behav. 1980;9(4):327.

Yüksel S, Kulaksizoglu IB, Türksoy N, Sahin D. Group psychotherapy with female-to-male transsexuals in Turkey. Arch Sex Behav. 2000;29(3):279-91.

Yuzgun A. Homosexuality and police terror in Turkey. $J$ Homosex. 1993;24(3-4):159-69.

Zhou JN, Hofman MA, Gooren LJG, Swaab DF. A sex difference in the human brain and its relation to transsexuality. Nature. 1995;378:68-70.

Zucker KJ, Bradley SJ, Sanikhani M. Sex differences in referral rates of children with gender identity disorder. J Abnorm Child Psychol. 1996;25(3):217-27. 